\author{
Federal Reserve Bank of Dallas \\ Globalization and Monetary Policy Institute \\ Working Paper No. 166 \\ http://www.dallasfed.org/assets/documents/institute/wpapers/2013/0166.pdf
}

\title{
Database of Global Economic Indicators (DGEI): A Methodological Note *
}

Valerie Grossman
Federal Reserve Bank of Dallas
Adrienne Mack

Federal Reserve Bank of Dallas

\author{
Enrique Martínez-García \\ Federal Reserve Bank of Dallas
}

December 2013

(Revised April 2014)

\begin{abstract}
The Database of Global Economic Indicators (DGEI) from the Federal Reserve Bank of Dallas is aimed at standardizing and disseminating world economic indicators for policy analysis and scholarly work on the role of globalization. The purpose of DGEI is to offer a broad perspective on how economic developments around the world influence the U.S. economy with a wide selection of indicators. DGEI is automated within an Excel-VBA and E-views framework for the processing and aggregation of multiple country time series. It includes a core sample of 40 countries with available indicators and broad coverage. Country groupings include rest of the world (ex. the U.S.) aggregates and subgroups of countries by development attainment and trade openness. The indicators currently tracked include real GDP, industrial production (IP), Purchasing Managers' Index (PMI), merchandise exports and imports, headline CPI, CPI (ex. food and energy), PPI/WPI inflation, nominal and real exchange rates, official/policy interest rates, and long-term interest rates. All series are monthly, with the exception of real GDP which is reported at a quarterly frequency. Aggregation is based on trade shares with the U.S. The Globalization and Monetary Policy Institute publishes the aggregate indicators as well as additional country detail on its website with an accompanying slideshow on Global Economic Conditions. This note provides a technical description of the methodology implemented to construct the DGEI.
\end{abstract}

JEL codes: C80, C82, E00, E66, F6

\footnotetext{
* Enrique Martínez-García, Federal Reserve Bank of Dallas, 2200 N. Pearl Street, Dallas, TX 75201. 214-922-5262. enrique.martinez-garcia@dal.frb.org. https://sites.google.com/site/emg07uw/. Valerie Grossman, Federal Reserve Bank of Dallas, 2200 N. Pearl Street, Dallas, TX 75201. 214-922-6367. valerie.grossman@dal.frb.org. Adrienne Mack, Federal Reserve Bank of Dallas, 2200 N. Pearl Street, Dallas, TX 75201. 214-922-5793. adrienne.mack@dal.frb.org. We acknowledge Alexander Chudik, Scott Davis, Adriana Fernández, Joseph Gruber, Michael Sposi, Jian Wang, and Mark Wynne for providing helpful comments and suggestions. The work on dating the global cycle has benefited from our collaboration with Shushanik Papanyan on developing coincident indicators of the economic cycle, and her insights are duly noted. This draft is still a work-in-progress as we continue to develop the database itself. The views expressed in this paper are those of the authors and do not necessarily reflect the views of the Federal Reserve Bank of Dallas or the Federal Reserve System.
} 


\section{Table of Contents}

1 Introduction: Aims and Scope........................................................................................................ 4

2 Taxonomy of the Database of Global Economic Indicators (DGEI) .................................... 6

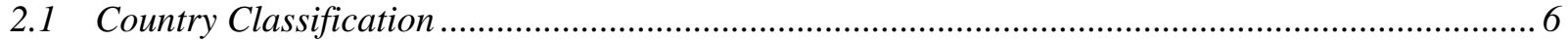

2.1.1 By Income or Level of Development ............................................................................... 6

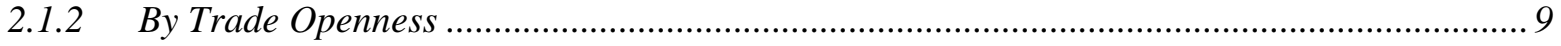

3 Construction of the Database of Global Economic Indicators (DGEI) ............................ 12

3.1 Main Global Economic Indicators..................................................................................... 12

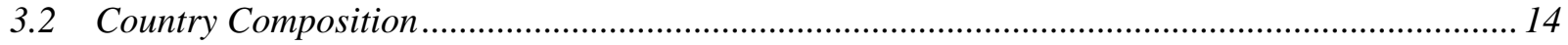

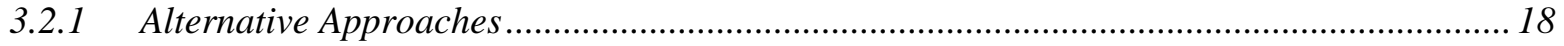

3.3 Pre-processing the Data (at the Country Level) ...................................................................... 18

3.3.1 Real Economic Activity Indicators..............................................................................19

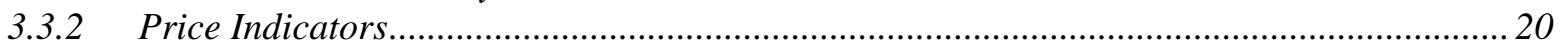

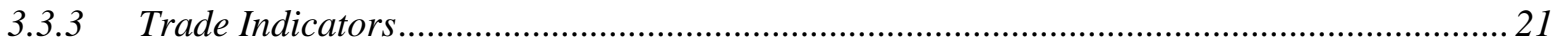

3.3.4 Financial Indicators.......................................................................................... 22

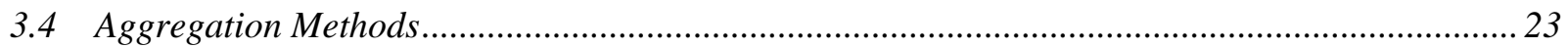

3.5 Exact Growth Rate Formulas ………………………………………………………..... 25

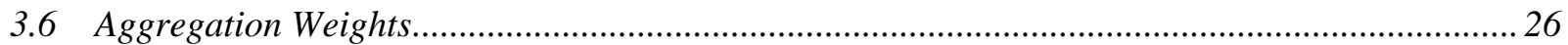

3.7 Unbalanced Datasets .................................................................................................... 28

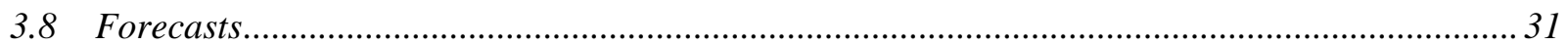

$4 \quad$ Dating the Global Cycle ........................................................................................................................ 33

5 The Database of Global Economic Indicators (DGEI): Summary ....................................... 35

5.1 Real Economic Activity Indicators....................................................................................... 36

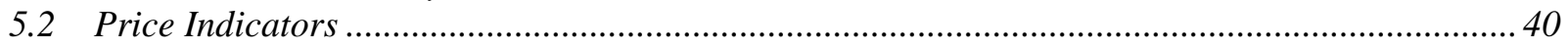

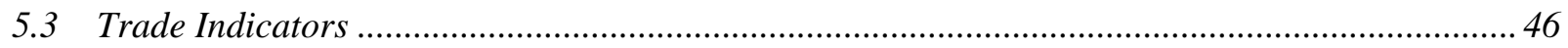

5.4 Financial Indicators........................................................................................................... 50

6 The Database of Global Economic Indicators (DGEI): Country Detail ............................ 52

$7 \quad$ General Bibliographic References ......................................................................................... 58

Appendix A. Country Definition ........................................................................................................6 60

Appendix B. An Assessment of the Quadratic-Match Method for Interpolation.................... 62

Appendix B.1. Implementation of the Interpolating Methods ...............................................................6 63

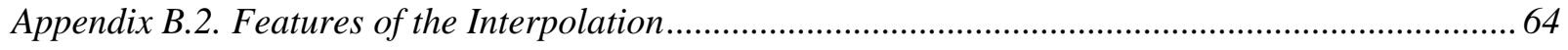

Appendix C. Country Sources ............................................................................................................. 72 


\section{List of Tables}

Table 1. Country Classification by Income or Level of Development ...................................... 8

Table 2. Country Classification by Trade Openness ............................................................ 11

Table 3. Main Reference Economic Indicators.................................................................. 12

Table 4. Data Availability for Countries with Coverage for Macro Variables of Interest ........... 15

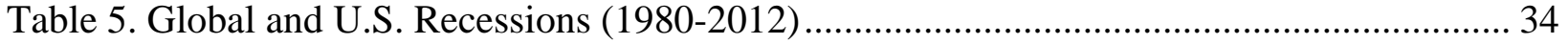

Table 6. U.S. and Top-20 Foreign Economies by Size in 2005............................................. 52

Table 7. Country Sources on Real Gross Domestic Product ................................................ 72

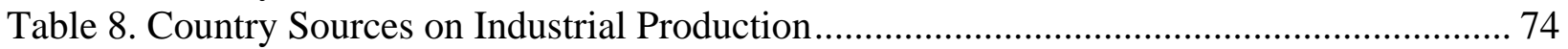

Table 9. Country Sources on Purchasing Managers' Index ....................................................... 76

Table 10. Country Sources on Headline Consumer Price Index ............................................. 77

Table 11. Country Sources on Core Consumer Price Index ................................................... 79

Table 12. Country Sources on Producer Price Index/Wholesale Price Index.............................. 81

Table 13. Country Sources on Merchandise Imports........................................................... 83

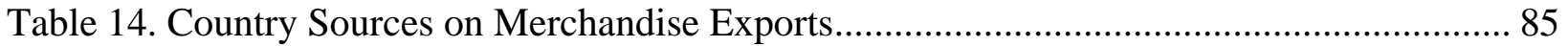

Table 15. Country Sources on Nominal Exchange Rates .................................................... 87

Table 16. Country Sources on Official/Policy Rates ........................................................... 89

Table 17. Country Sources on Long-Term Bond Yields ...................................................... 91 


\section{List of Figures}

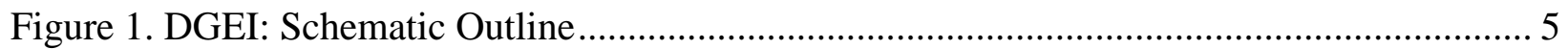

Figure 2. Distribution of PPP-adjusted GDP per Capita (1980-2012)....................................... 7

Figure 3. Distribution of the Ratio of Trade Openness (1980-2012)....................................... 10

Figure 4. Circular Flow Model of the Economy and Economic Indicators ............................... 13

Figure 5. Country Classification by Income or Level of Development..................................... 16

Figure 6. Country Classification by Trade Openness ......................................................... 16

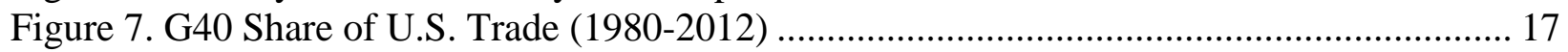

Figure 8. G40 Share of PPP-adjusted World GDP (1980-2012) ............................................ 17

Figure 9. U.S. Trade Shares Accounted for by G40 Countries (1980-2012)............................ 29

Figure 10. Shares of World GDP (PPP) Accounted for by G40 Countries (1980-2012) ............ 30

Figure 11. Date-stamping the Global Cycle (1980-2012) .................................................. 34

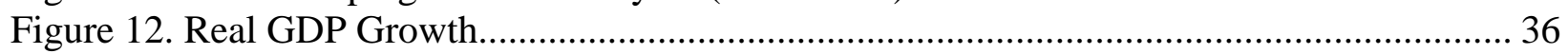

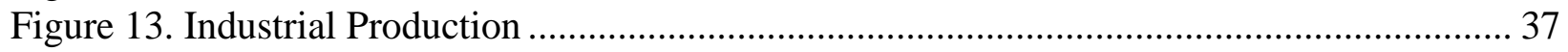

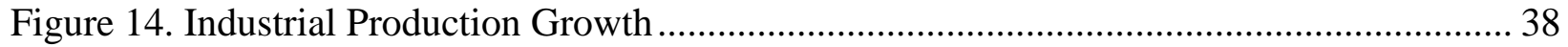

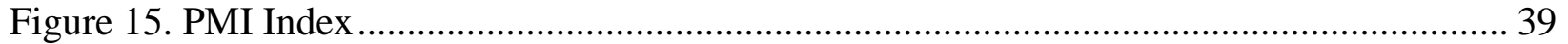

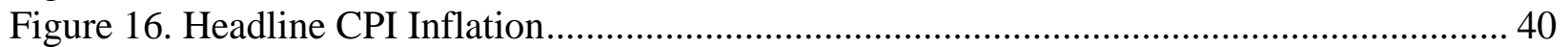

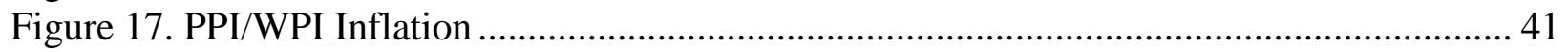

Figure 18. Core CPI Inflation (ex. Food and Energy) ..................................................... 42

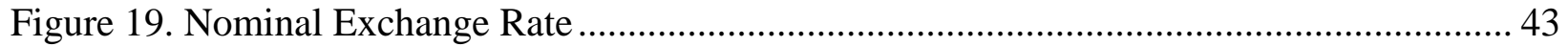

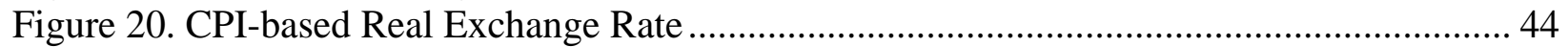

Figure 21. PPI/WPI-based Real Exchange Rate ............................................................... 45

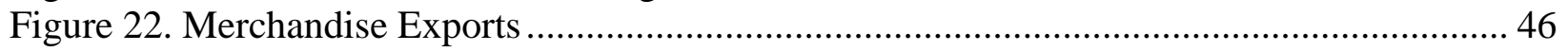

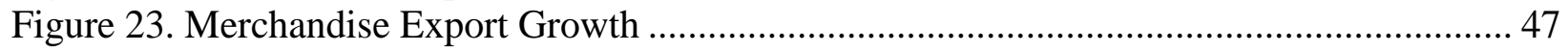

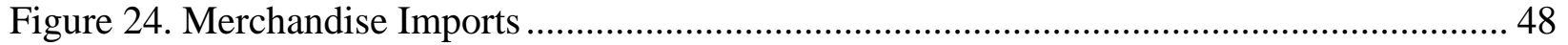

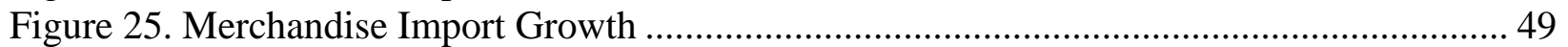

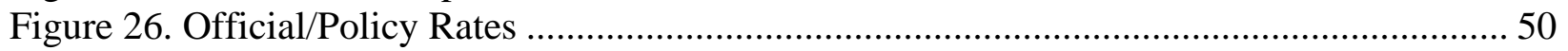

Figure 27. Long-Term Bond Yields.......................................................................... 51

Figure 28. Country Detail: Euro Area, United Kingdom, and Japan....................................... 53

Figure 29. Country Detail: Canada, Australia, and Brazil .................................................... 54

Figure 30. Country Detail: Russia, India, and China ....................................................... 55

Figure 31. Country Detail: South Africa, Mexico, and Indonesia ........................................... 56

Figure 32. Country Detail: South Korea and Turkey............................................................ 57

Figure 33. Accuracy of the Quadratic-match Relative to the Partial-sum Cubic Spline with the

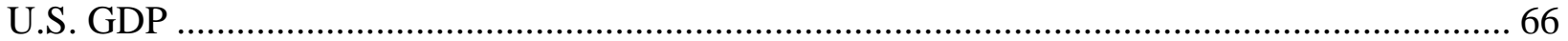

Figure 34. Accuracy of the Quadratic-match Relative to the Partial-sum Cubic Spline with the

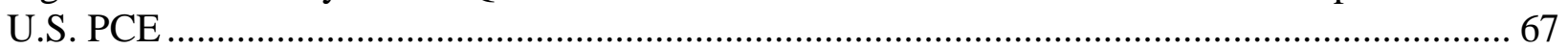

Figure 35. Accuracy of the Quadratic-match Relative to the Partial-sum Cubic Spline with the

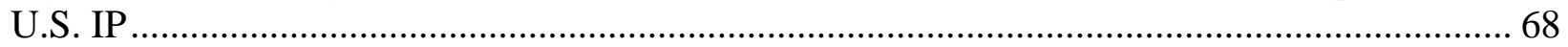

Figure 36. Accuracy of the Quadratic-match Relative to the Partial-sum Cubic Spline with the

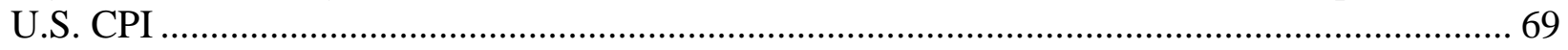

Figure 37. Accuracy of the Quadratic-match Relative to the Partial-sum Cubic Spline with the

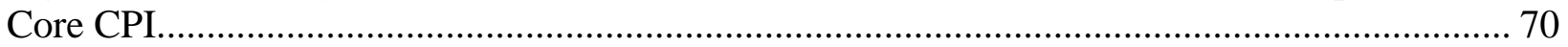

Figure 38. Accuracy of the Quadratic-match Relative to the Partial-sum Cubic Spline with the

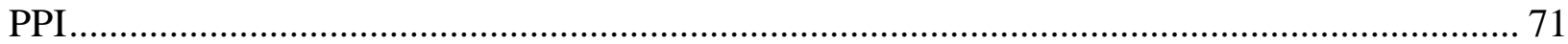


"Data! Data! Data!" he cried impatiently. "I can't make bricks without clay." The Adventure of the Copper Beeches (1892), in The Adventures of Sherlock Homes, by Sir Arthur Conan Doyle (1859-1930).

\section{Introduction: Aims and Scope}

The Database of Global Economic Indicators (DGEI) is intended to deal with the problem of "not seeing the forest for the trees" in economic and policy analysis of international developments. In other words, it aims to provide a broad perspective on the world economy that is less subject to idiosyncratic country factors and more indicative of the global factors at play. The DGEI reflects a major effort of the Globalization and Monetary Policy Institute of the Federal Reserve Bank of Dallas. The DGEI aims to standardize and simplify data management processes to document the common features of the international data-by pre-processing the relevant time series across countries and automating the country aggregation to ensure timeliness and comparability across sources.

The DGEI system of data processing is described schematically in Figure 1 below. DGEI uses country data primarily from Haver Analytics for its current series. It channels a variety of historical data sources as well — going back to 1980 whenever possible - to extend the current series. The DGEI data management system is implemented within an Excel environment that integrates Visual Basic for Applications (VBA) code and E-views 8 code for the compilation of monthly and quarterly indicators at the country level and aggregation of the data.

We are mindful that the reliability and interpretability of the aggregate indicators we produce very much depends on the implementation process we detail here. DGEI depends crucially on the methodology described in this document, to explain what the indicators capture and what these aggregates can tell us about the global outlook.

The work we've done offers a new look at global economic developments and the global outlook (through Global Economic Conditions web updates and charts, and data releases) from a U.S. perspective. We hope that this resource will be regularly used to complement other available sources (such as the IMF database, the World Bank database, the United Nations datasets, etc.). With this initiative, the Federal Reserve Bank of Dallas wants to contribute to international macroeconomic research that deepens our understanding about the role of globalization and its effects on the U.S.

The paper is organized as follows: In Section 2 we describe our country classification taxonomy. Section 3 provides an overview of the selection criteria used to construct the DGEI database. It also has a detailed discussion on the methodology to obtain the time series of indicators we use, our aggregation approach, and the way we incorporate forecasts (whenever country forecasts differ in terms of growth definitions and frequency). Section 4 introduces the method for dating turning points of the global business cycle (see Grossman, Mack, and Martínez-García (2014)). Section 5 illustrates the DGEI indicators for the period 1999-2013, while Section 6 presents the country detail for the major world economies that complements our aggregate indicators. 
Figure 1. DGEI: Schematic Outline

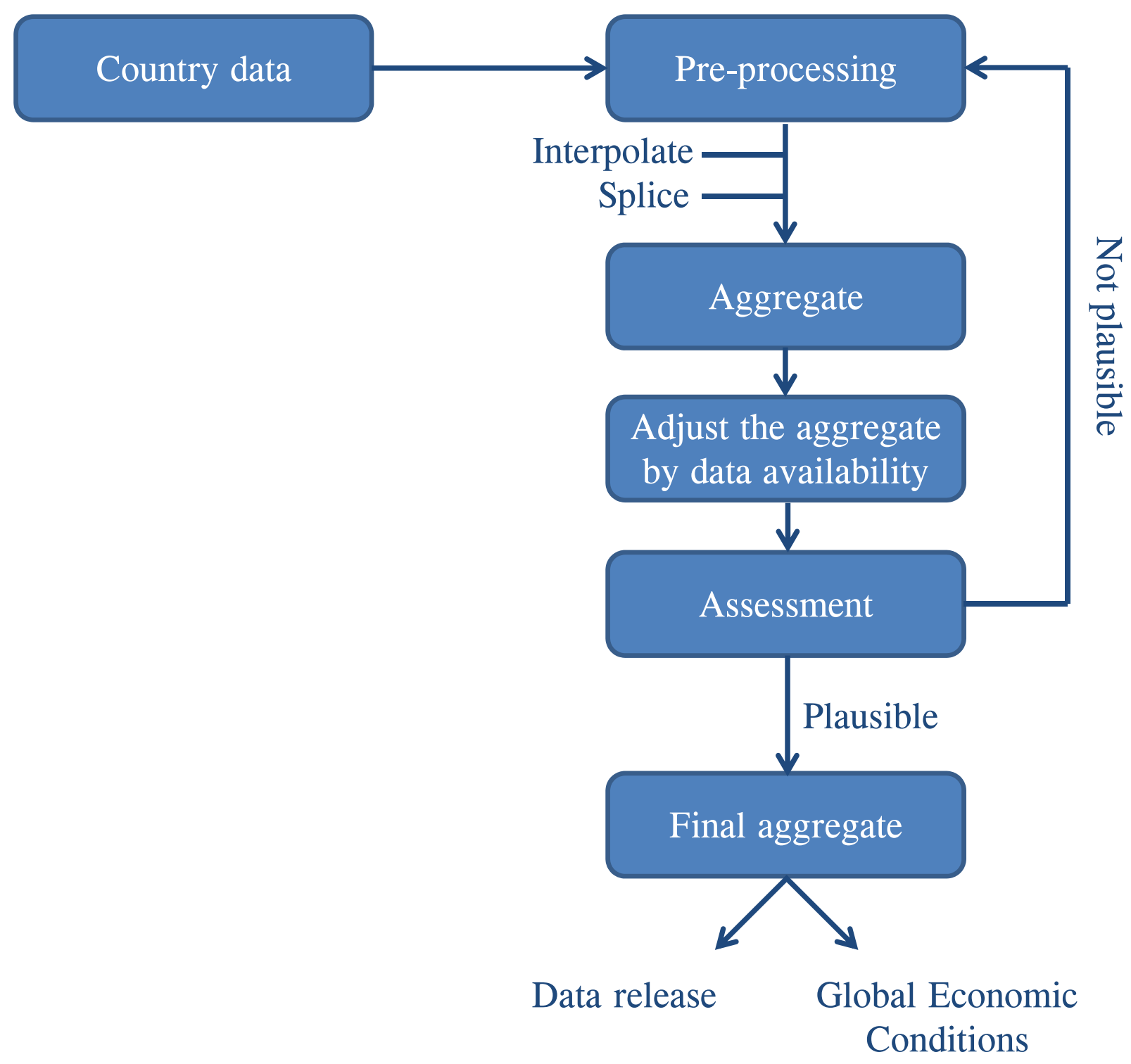




\section{Taxonomy of the Database of Global Economic Indicators (DGEI)}

\subsection{Country Classification}

\subsubsection{By Income or Level of Development}

The methodology for classifying countries by economic development varies among international organizations, as described in Nielsen (2011). The process used by the U.N. Development Programme (UNDP), the World Bank, and the International Monetary Fund (IMF differ in the development indicators they rely upon, and the absolute/relative nature of the thresholds underlying their classification. However, all seem to reach similar conclusions in their 'developed/advanced’ and ‘developing/emerging' country groupings.

The World Bank sets development thresholds based on estimates of gross national income (GNI) per capita (see, e.g., World Bank (2013)). The UNDP uses the Human Development Index (HDI), which is a composite statistic of life expectancy, education, and income measures (see, e.g., UNDP (2013)). The IMF has no detailed discussion of its classification methodologyalthough its country classification appears to be highly correlated with measures of income (see, e.g., IMF (2013)).

The World Bank country classification has been kept fairly invariant in real terms - setting effectively an absolute development threshold. The IMF's implicit threshold is probably also based on an absolute level, according to Nielsen (2011). With an upward trending average world income, an absolute threshold for 'developed/advanced' countries could result in further expansion of this grouping. In turn, UNDP's development threshold is set in relative termsdetermined by the upper quartile of the HDI distribution-to keep the composition of the grouping stable over time.

Our development classification for the DGEI is based on a relative income threshold. We classify countries as advanced or emerging based on PPP-adjusted real GDP per capita from the IMF World Economic Outlook (WEO), using annual data from 1980 until 2012 for 183 countries and overseas/dependent territories (see Appendix A. Country Definition for further details). Since GDP per capita trends upwards for most countries (Figure 2), the metric used to classify each country is not PPP-adjusted GDP per capita per se but the frequency with which the country's PPP-adjusted GDP per capita falls below the upper quartile of the cross-country distribution in each year over the period 1980-2012.

We set a relative threshold in order to account for changes in the distribution over time, ensuring only countries that persistently appear in the upper quartile of the distribution are considered for the 'advanced' group. Countries may surpass this relative development threshold for just a few years, and not be considered advanced. Countries that fell below the upper quartile at least 20 percent of the time since the 1980s are classified as emerging by their development attainment. 
Figure 2. Distribution of PPP-adjusted GDP per Capita (1980-2012)

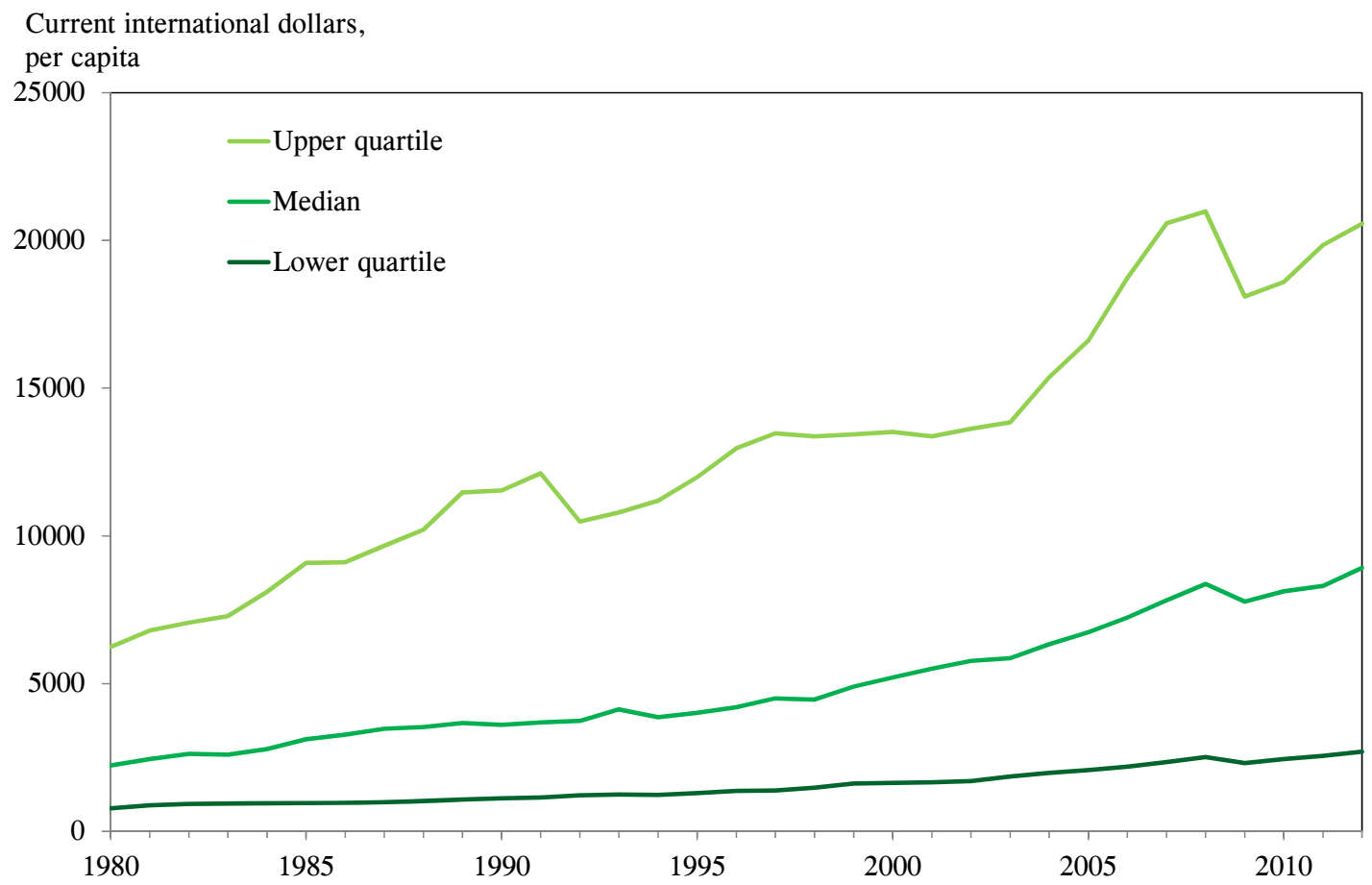

Source: IMF World Economic Outlook (WEO) database.

Advanced countries are high-income countries - but the classification is not entirely determined by income since a country's economic development classification is subject to two important adjustments:

(a) Any country whose economy is heavily dependent on oil production (irrespective of whether they are high-income or not) are re-classified as emerging to define a broader grouping of emerging and oil-producing countries. To determine a country's dependence on oil production, we use non-oil GDP, total GDP, and population data obtained from the IMF's April 2010 World Economic Outlook (WEO) ( IMF (2010)). We measure the degree of oil dependence as the ratio of total GDP minus non-oil GDP over total GDP, both in real terms. Oil-producers are those whose oil-dependence ratio is consistently in the upper quartile of the distribution.

(b) Any country whose economy's share of world PPP-adjusted GDP does not reach 0.01 percent at least half of the time during the period 1980-2012 is also excluded from the advanced group. 
Table 1 summarizes the country classification which includes a total of 36 advanced countries. The resulting classification is almost identical to the one the IMF uses in its 2013 World Economic Outlook (WEO) as seen in IMF (2013). For further details on alternative classification methods and country lists, see also the work of Nielsen (2011).

\section{Table 1. Country Classification by Income or Level of Development}

\begin{tabular}{|c|c|c|c|}
\hline \multicolumn{4}{|c|}{ Advanced-Economy Grouping } \\
\hline $2 \%$ & Australia & 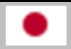 & Japan \\
\hline & Austria & - & Luxembourg \\
\hline & Bahamas & 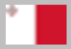 & Malta \\
\hline & Belgium & & Netherlands \\
\hline 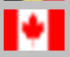 & Canada & Wa & New Zealand \\
\hline 8 & Cyprus & 故 & Norway \\
\hline & Czech Republic & $\theta$ & Portugal \\
\hline +E & Denmark & $\mathrm{sen}$ & Singapore \\
\hline & Estonia & 8 & Slovakia \\
\hline & Finland & ? & Slovenia \\
\hline & France & 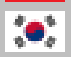 & South Korea \\
\hline & Germany & $\bar{c}$ & Spain \\
\hline 琵 & Greece & 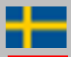 & Sweden \\
\hline th & Hong Kong & 4 & Switzerland \\
\hline 믐 & Iceland & D & Taiwan \\
\hline 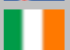 & Ireland & 1 & Trinidad and Tobago \\
\hline$\frac{1}{4}$ & Israel & $\frac{a}{2}$ & U.K. \\
\hline & Italy & 를 & U.S. \\
\hline
\end{tabular}

Note: The IMF country classification includes 35 advanced economies (including the U.S.), which can be found in their October 2013 World Economic Outlook (WEO) database (http://www.imf.org/external/pubs/ft/weo/2013/02/). The IMF includes San Marino as an advanced economy, and we include Bahamas and Trinidad and Tobago in that category instead. 


\subsubsection{By Trade Openness}

We also classify countries as open economies and closed economies to distinguish countries whose trade to GDP ratio is significantly higher than the rest. The closed-economy grouping includes all others. Hence, under the label of closed economies we include a large number of countries - including the U.S.- - which are integral to world trade but are simply less geared towards trade.

Economies that are more dependent on trade-labeled as open-are arguably more sensitive to global factors. We recognize, however, that economies labeled as closed may in fact have more of an impact on world trade and global developments through their sheer size or role in the global value-added chain (e.g., in the case of the U.S.) than those in the open-economy grouping. The distinction is primarily meant to illustrate differences in the global outlook depending on the degree of openness of an economy, but also to capture the differential impact from the point of view of the U.S. of developments across these two groupings.

The classification by trade openness is based on the annual ratio of nominal trade (exports plus imports) in U.S. dollars divided by the nominal GDP of the country expressed in U.S. dollars. All exports are valued free on board (f.o.b.). Imports are usually reported as cost including insurance and freight (c.i.f.), although a few countries report imports f.o.b. For our calculations, the import data reported f.o.b. are adjusted to a c.i.f. basis by applying an across-the-board 10 percent increase in all cases to account for the costs of insurance and freight. The annual data used comes from the IMF's International Financial Statistics (IFS) database and covers the same 183 countries reviewed for the classification by level of development.

Trade openness has varied significantly as the world has become more integrated (see, e.g., the changes in the quartiles since 1980 illustrated in Figure 3). To account for that fact, a relative threshold that controls for changes in the distribution over time is used in classifying these countries. The median of the distribution-which is a measure of central tendency and more robust in the presence of outliers than the mean-is computed for each year over the period 1980-2012. The median has trended upwards since the mid-1980s, so the frequency with which a given country has been below the median of the distribution for all years from 1980 until 2012 for which there is data determines its classification by degree of openness. 
Countries are classified as closed economies whenever they appear to be above the median 5 percent of the time or less, and consequently all other countries are classified as open. Any country whose economy's share of world PPP-adjusted GDP does not reach 0.01 percent at least half of the time during the period 1980-2012 is automatically classified as open. Because their economy is so small, they are naturally dependent on trade with the rest of the world.

Figure 3. Distribution of the Ratio of Trade Openness (1980-2012)

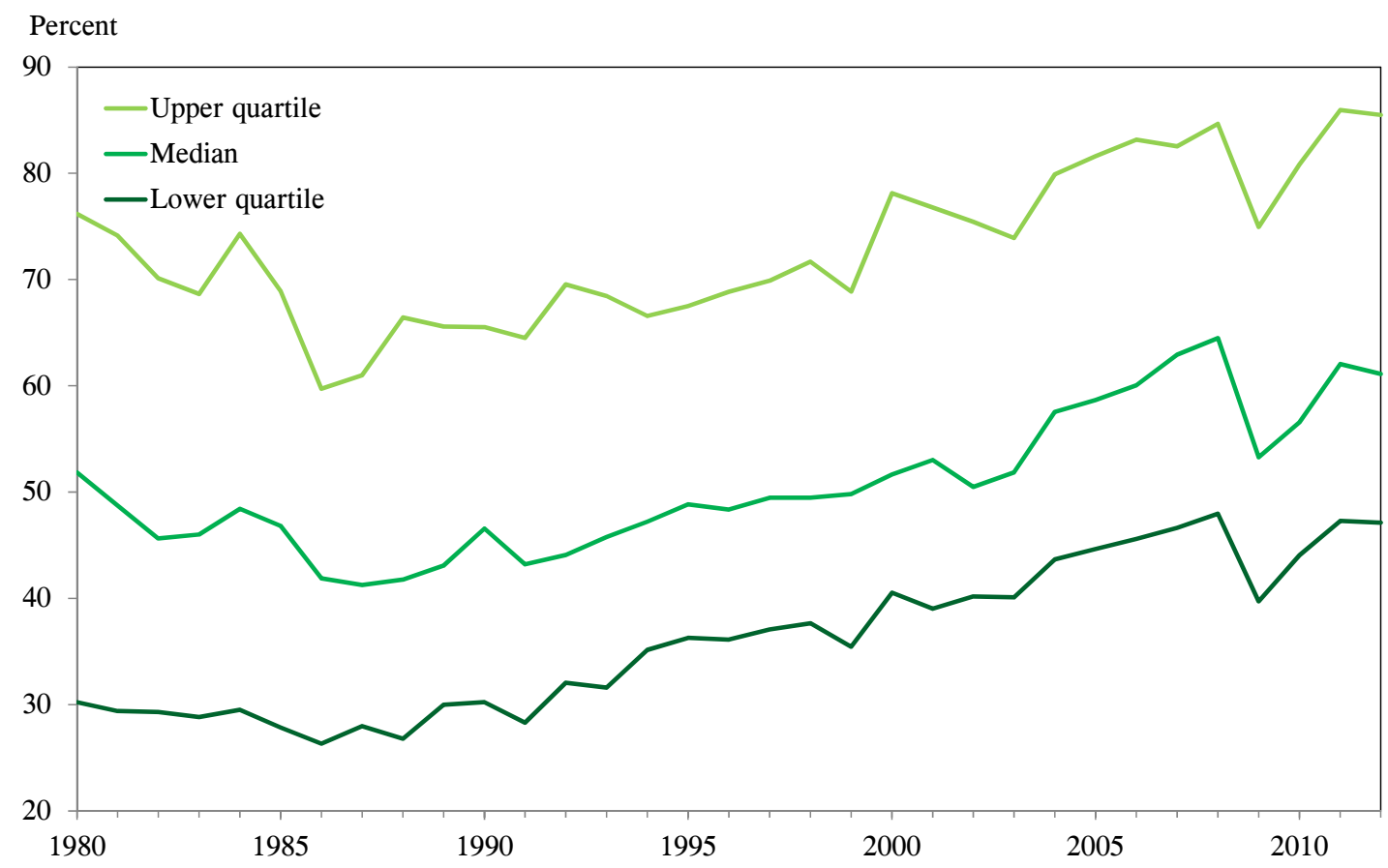

Source: IMF International Financial Statistics (IFS) database. 
Table 2 summarizes the country classification which includes a total of 42 closed-economy countries.

Table 2. Country Classification by Trade Openness

\begin{tabular}{|c|c|c|c|}
\hline \multicolumn{4}{|c|}{ Closed-Economy Country Grouping } \\
\hline * & Albania & - & Japan \\
\hline$\because$ & Argentina & 르르 & Kenya \\
\hline$\%$ & Australia & & Madagascar \\
\hline 0 & Bangladesh & - & Mexico \\
\hline$\theta$ & Brazil & D & Namibia \\
\hline * & Burkina Faso & B & Nepal \\
\hline 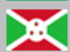 & Burundi & 0 & Niger \\
\hline * & Cameroon & c & Pakistan \\
\hline تE & Central African Republic & * & Panama \\
\hline$=$ & Colombia & D & Peru \\
\hline C & Comoros & 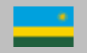 & Rwanda \\
\hline EDa & Dominican Republic & 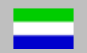 & Sierra Leone \\
\hline$=$ & Egypt & 두 & Spain \\
\hline 믈 & Ethiopia & $=$ & Sudan \\
\hline 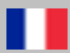 & France & $Z$ & Tanzania \\
\hline & Greece & $\Rightarrow$ & Timor-Leste \\
\hline$\theta$ & Guatemala & $\mathrm{C}^{*}$ & Turkey \\
\hline * & Guinea-Bissau & $\overline{\bar{O}}$ & Uganda \\
\hline - & India & 幽造 & U.K. \\
\hline 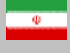 & Iran & 些 & U.S. \\
\hline 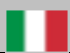 & Italy & 三 & Uruguay \\
\hline
\end{tabular}

Note: The country classification considers closed economies those that have experienced a low degree of openness to trade consistently since the 1980s, even if over time they have become more integrated. 


\section{Construction of the Database of Global Economic Indicators (DGEI)}

\subsection{Main Global Economic Indicators}

The time series listed in Table 3 represent our current selection of indicators in the DGEI. This (non-exhaustive) list includes a number of the most relevant macro variables used to gauge real and nominal developments around the world and to take the pulse of the global economy.

Table 3. Main Reference Economic Indicators

\begin{tabular}{|c|c|}
\hline Variables & Frequency \\
\hline \multicolumn{2}{|l|}{ Real Economic Activity Indicators } \\
\hline GDP & Quarterly \\
\hline Industrial Production & Monthly \\
\hline Purchasing Managers’ Index (PMI) & Monthly \\
\hline \multicolumn{2}{|l|}{ Price Indicators } \\
\hline Headline CPI Inflation & Monthly \\
\hline PPI/WPI Inflation & Monthly \\
\hline Core CPI Inflation & Monthly \\
\hline Nominal Exchange Rates & Monthly \\
\hline Real (CPI-based) Exchange Rates & Monthly \\
\hline Real (PPI-based) Exchange Rates & Monthly \\
\hline \multicolumn{2}{|l|}{ Trade Indicators } \\
\hline $\begin{array}{l}\text { Merchandise Exports to World } \\
\text { Merchandise World Imports }\end{array}$ & Monthly \\
\hline \multicolumn{2}{|l|}{ Financial Indicators } \\
\hline Short-term Policy Rates & Monthly \\
\hline t Rates & \\
\hline
\end{tabular}

Note: The GDP series is computed as an index, and expressed in levels in PPP-adjusted terms in international U.S.\$. Among the 13 indicators listed in this table, nine of them are considered to be core indicators for which all countries in DGEI must have some data at least as far back as 2005. Of the four non-core indicators of reference, PPI/WPI inflation, real (PPI-based) exchange rates, and long-term interest rates have nearly complete country coverage in DGEI, and only the PMI series is subject to significant data limitations.

The external sector is critical to our understanding of an increasingly more integrated global economy. Different parts of the U.S. economy are inextricably linked to the rest of the world, so the DGEI indicators serve like a thermometer reading for developments abroad that could spill over to the U.S.

Figure 4 illustrates in blue a stylized representation of the circular flow model of an economy connected to the rest of the world. The same figure illustrates in purple the main linkages between the selected DGEI reference indicators and their relation to the circular flow representation. Foreign events captured by the indicators selected for DGEI can influence developments both abroad as well as in the U.S. and are important to track. 
Figure 4. Circular Flow Model of the Economy and Economic Indicators
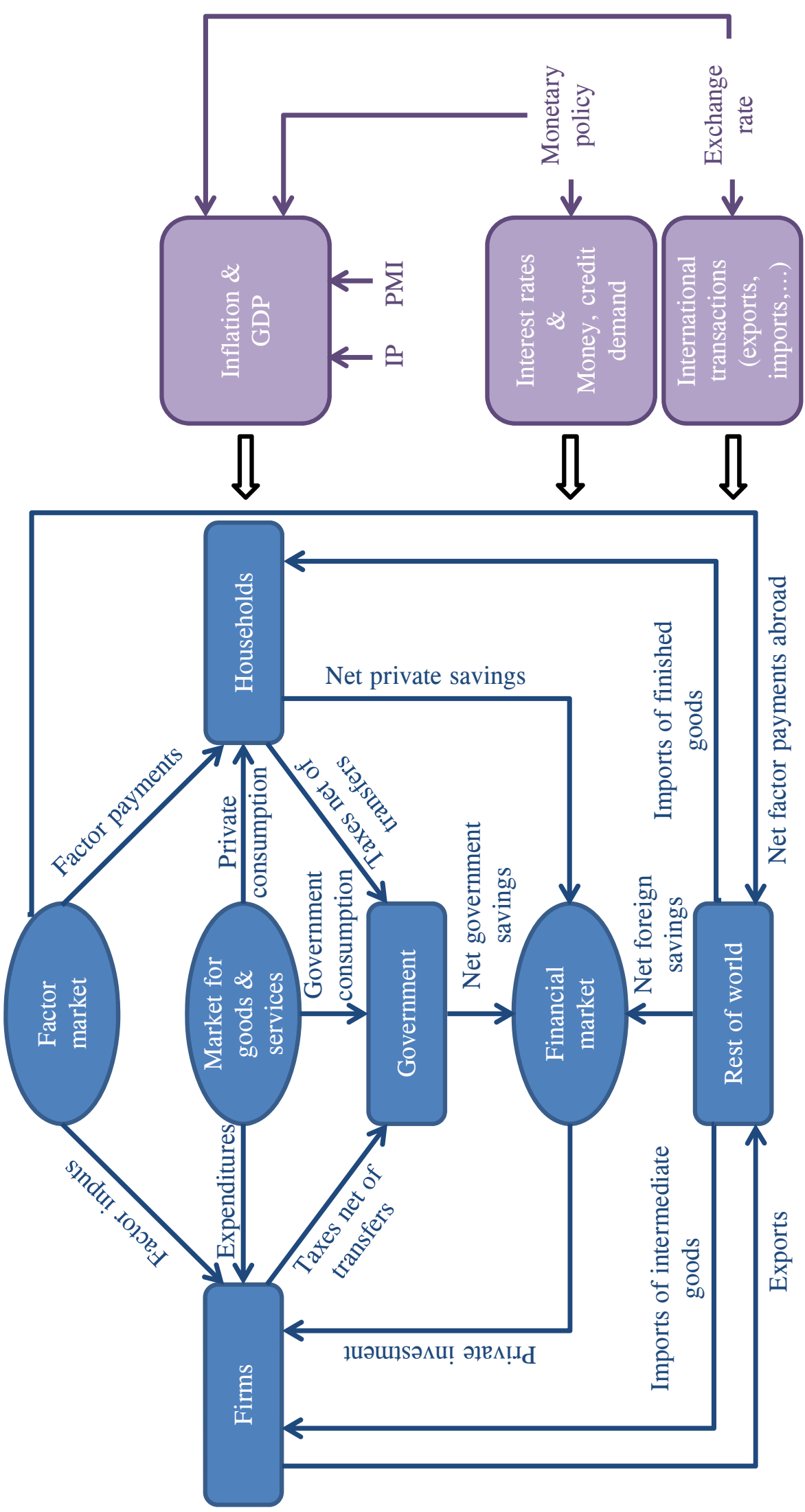


\subsection{Country Composition}

Building a representative panel of countries for the DGEI requires consistent selection criteria:

- Pre-screening for data availability: There is readily available data on all key macro indicators listed in Table 3 for at least 58 countries starting in 2005 or earlier, but the time series coverage is not complete for all 58 countries going back to $1980 .{ }^{1}$

o All 58 countries are included in Table 4, classified as either emerging or advanced and ranked by the size of their economies in 2005 PPP-adjusted terms.

- Selection: Out of the 58 countries in Table 4, the main criteria used to refine the country sample were: (a) economic size, and (b) economic representativeness. The former criterion narrows the sample of countries to those with a significant weight in the global economy, while the latter criterion evaluates a country's significance within its assigned development country grouping. To be included, a country must account for at least 75 percent of the advanced (ex. the U.S.) or emerging shares of world PPP-adjusted GDP going back to 2005 or earlier. Economic representativeness aims to guarantee that the country sample is balanced (at least in regards to development attainment)

o The 26 emerging countries listed in Table 4 represent 77.37 percent of the world output share accounted for by emerging economies. Some of the smaller countries with shorter time series and less reliable/timely data are not included to facilitate the data management of the DGEI-this brings down the number of emerging countries that we retain for the DGEI to 21 , representing 75.34 percent of the emerging economies' total in 2005.

o 32 out of the 36 advanced countries listed in Table 1 are included in the list of 58 countries reporting consistent data since 2005 or earlier - the smaller countries with a share of world output under 0.35 percent are excluded. Hong Kong and Norway are also excluded due to their particular circumstances-Hong Kong because of its special status as a Special Administrative Region of China and its role in China's trade with the rest of the world, and Norway because of the importance of oil to its economy. This reduces the number of advanced countries retained for the DGEI to 19 which still represent 94.55 percent of the advanced countries' share of world output in 2005.

o G40 country sample: The resulting sample of 40 advanced and emerging countries (including the U.S.) remains somewhat skewed towards the advanced economies, but because of their importance for the global economy as well as for international trade and the financial linkages of the U.S., we do not attempt to correct for the overrepresentation of the advanced economies.

\footnotetext{
${ }^{1}$ The only exceptions to that rule are India, Indonesia, and China, which report core CPI data starting in 2006, 2007, and 2005 respectively but are sufficiently large that they cannot be excluded from the panel. PPI/WPI inflation, real (PPI-based) exchange rates, and long-term interest rates have nearly complete country coverage in DGEI. Not all countries in the database report data for the PMI either, but the coverage is not nearly as complete. Of the 40 countries (out of the 58 identified in Table 4) currently incorporated as part of the DGEI, Belgium and Portugal are the only advanced countries for which we do not have a PMI series. In turn, we lack PMI data for Indonesia (which started to report in 2011), Thailand, Argentina, Colombia, Malaysia, Venezuela, Philippines, Niger, Chile, Peru, Bulgaria, and Costa Rica.
} 
Table 4. Data Availability for Countries with Coverage for Macro Variables of Interest

\begin{tabular}{|c|c|c|c|c|c|}
\hline \multirow[t]{2}{*}{ Advanced Countries } & \multicolumn{2}{|c|}{ PPP-adj. GDP Shares (2005) } & \multirow[t]{2}{*}{ Emerging Countries } & \multicolumn{2}{|c|}{ PPP-adj. GDP Shares (2005) } \\
\hline & G58 & G40 & & G58 & G40 \\
\hline U.S. & 22.16 & 22.16 & China & 9.42 & 9.42 \\
\hline Japan & 6.83 & 6.83 & India & 4.26 & 4.26 \\
\hline Germany & 4.38 & 4.38 & Russia & 2.98 & 2.98 \\
\hline U.K. & 3.42 & 3.42 & Brazil & 2.78 & 2.78 \\
\hline France & 3.27 & 3.27 & Mexico & 2.28 & 2.28 \\
\hline Italy & 2.88 & 2.88 & Turkey & 1.31 & 1.31 \\
\hline Spain & 2.08 & 2.08 & Indonesia & 1.24 & 1.24 \\
\hline Canada & 2.04 & 2.04 & Poland & 0.91 & 0.91 \\
\hline S. Korea & 1.93 & 1.93 & Thailand & 0.78 & 0.78 \\
\hline Australia & 1.21 & 1.21 & Argentina & 0.74 & 0.74 \\
\hline Taiwan & 1.07 & 1.07 & S. Africa & 0.71 & 0.71 \\
\hline Netherlands & 1.00 & 1.00 & Colombia & 0.55 & 0.55 \\
\hline Belgium & 0.59 & 0.59 & Malaysia & 0.55 & 0.55 \\
\hline Sweden & 0.53 & 0.53 & Venezuela & 0.46 & 0.46 \\
\hline Austria & 0.49 & 0.49 & Philippines & 0.46 & 0.46 \\
\hline Switzerland & 0.48 & 0.48 & Nigeria & 0.43 & 0.43 \\
\hline Greece & 0.48 & 0.48 & Chile & 0.36 & 0.36 \\
\hline Hong Kong & 0.44 & -- & Romania & 0.36 & -- \\
\hline Norway & 0.39 & -- & Peru & 0.31 & 0.31 \\
\hline Portugal & 0.38 & 0.38 & Hungary & 0.30 & 0.30 \\
\hline Czech Rep. & 0.38 & 0.38 & Kazakhstan & 0.23 & -- \\
\hline Singapore & 0.34 & -- & Bulgaria & 0.14 & 0.14 \\
\hline Denmark & 0.32 & -- & Croatia & 0.12 & -- \\
\hline Israel & 0.28 & -- & Lithuania & 0.09 & -- \\
\hline Finland & 0.28 & -- & Costa Rica & 0.07 & 0.07 \\
\hline Ireland & 0.28 & -- & Jordan & 0.04 & -- \\
\hline New Zealand & 0.18 & -- & & & \\
\hline Slovakia & 0.15 & -- & & & \\
\hline Slovenia & 0.08 & -- & & & \\
\hline Cyprus & 0.03 & -- & & & \\
\hline Iceland & 0.02 & -- & & & \\
\hline Malta & 0.02 & -- & & & \\
\hline $\begin{array}{l}\text { World share of } \mathbf{G 5 8 / G 4 0} \\
\text { groupings }\end{array}$ & 58.42 & 55.61 & $\begin{array}{l}\text { World share of G58/G40 } \\
\text { groupings }\end{array}$ & 31.87 & 31.03 \\
\hline $\begin{array}{l}\text { G58/G40 share of the total } \\
\text { of G58/G40 }\end{array}$ & 64.70 & 64.18 & $\begin{array}{l}\text { G58/G40 share of the total } \\
\text { of } \mathbf{G 5 8 / G 4 0}\end{array}$ & 35.30 & 35.82 \\
\hline $\begin{array}{l}\text { World share of each } \\
\text { grouping }\end{array}$ & 58.81 & 58.81 & $\begin{array}{l}\text { World share of each } \\
\text { grouping }\end{array}$ & 41.19 & 41.19 \\
\hline
\end{tabular}

Note: PPP-adjusted GDP shares are from the IMF World Economic Outlook (WEO) database. We indicate the group of 40 countries included in the DGEI as G40 and all 58 countries with some data for our selection of economic indicators as G58. 
Figure 5 and Figure 6 illustrate the country classifications by economic development and trade openness that we have adopted for the DGEI. The U.S. is an advanced and closed economy based on our classification, but our advanced and closed-economy aggregates (as well as the rest of the world) exclude the U.S. for contrast.

\section{Figure 5. Country Classification by Income or Level of Development}

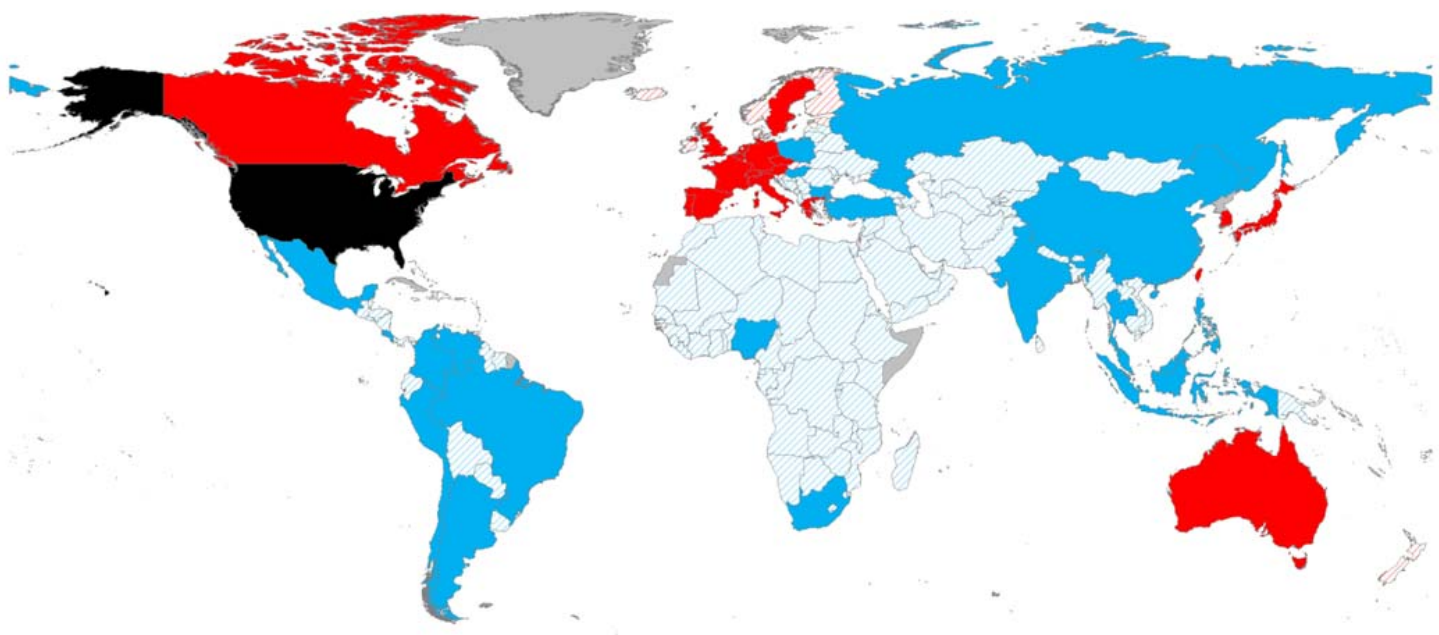

Non-G40 Emerging

Non-G40 Advanced (ex. U.S.)

G40 Advanced (ex. U.S.)

Not in Sample

Figure 6. Country Classification by Trade Openness

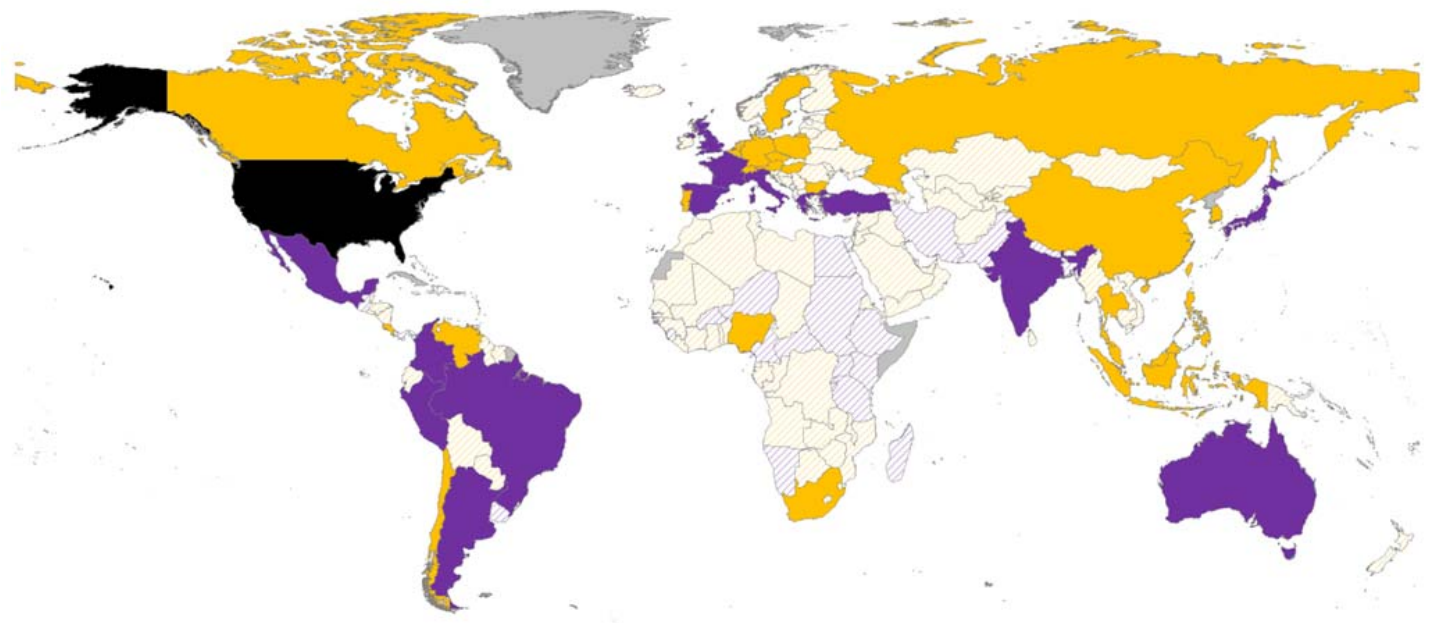

\footnotetext{
U.S.

Non-G40 Closed (ex. U.S

Non-G40 Open

G40 Closed (ex. U.S

G40 Open

Not in Sample
} 
The G40 country selection adopted for DGEI represents a fairly stable share of U.S. trade for the period of reference since 1980 (Figure 7), as well as a stable share of world GDP in PPP-adjusted terms (Figure 8). Moreover, the G40 sample also reflects two major structural changes that have occurred since the 1980s:

- The share of U.S. trade accounted for by emerging countries has more than doubled since 1987.

- The share of world GDP accounted for by emerging countries has significantly increased since 2000.

Figure 7. G40 Share of U.S. Trade (1980-2012)

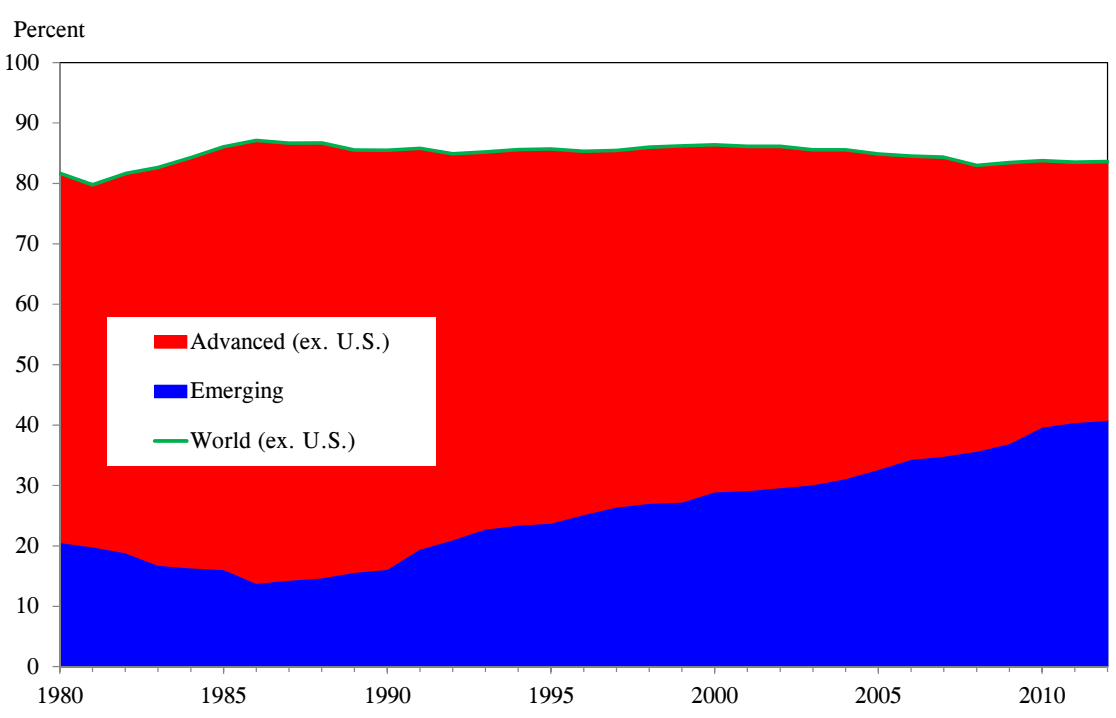

Source: Trade data comes from the IMF Direction of Trade (DOT) database.

Figure 8. G40 Share of PPP-adjusted World GDP (1980-2012)

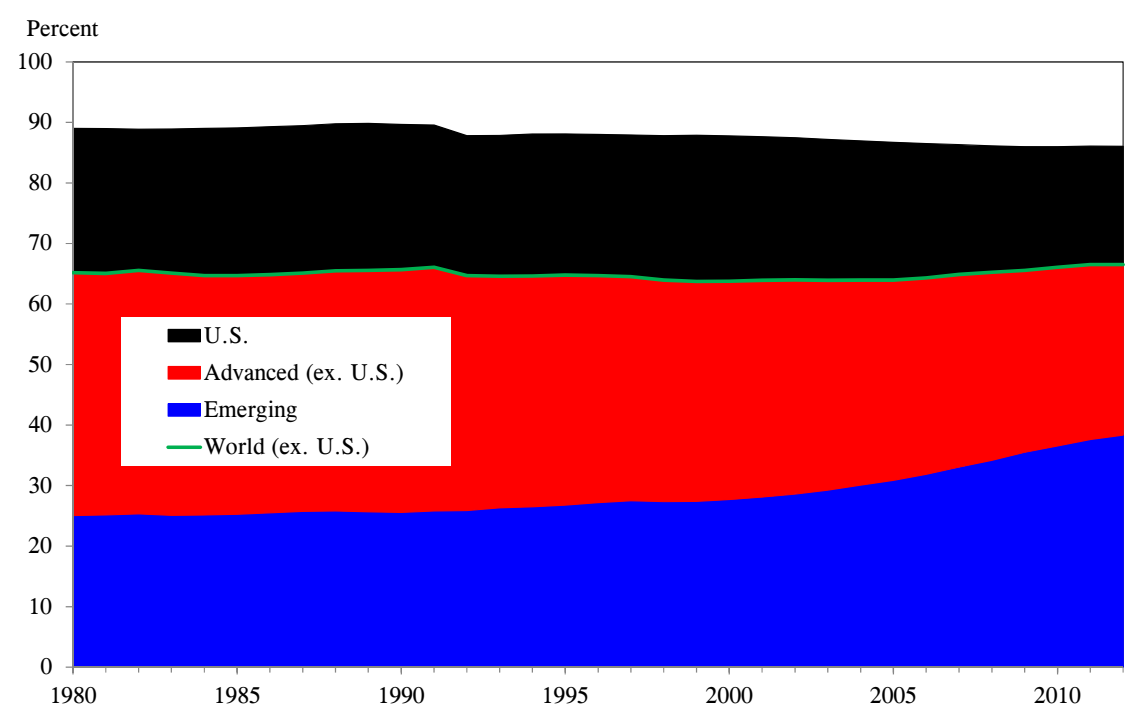

Source: PPP-adjusted GDP shares are from the IMF World Economic Outlook (WEO) database. 


\subsubsection{Alternative Approaches}

An alternative approach to country selection/classification is used in the construction of the foreign exchange value of the dollar. See Loretan (2005) for details on the construction of that index by the Board of Governors (BoG).

o The country selection methodology explained in Loretan (2005) is based on the largest trading partners of the U.S., while country selection in DGEI is based on the economic size of the countries, as measured by their share of world GDP conditioned by data availability of the main reference indicators.

o DGEI includes a broader set of emerging countries than those of the BoG's index. We expect this feature to be important going forward, since the trends from the mid-1980s suggest that emerging economies represent an increasingly larger share of world output and since U.S. trade is increasingly shifting towards the emerging economies.

- Euro-area countries included in the BoG index but not included in the DGEI sample are: Finland, Ireland, Luxembourg, Cyprus, Estonia, Malta, Slovakia, and Slovenia. Other countries included in the BoG index but not in the DGEI are: Hong Kong, Singapore, Israel, and Saudi Arabia. All these countries are considered advanced in DGEI (except Saudi Arabia which is classified as an oil-producer).

- Countries included in the DGEI sample but not in the BoG: Turkey, South Africa, Costa Rica, Peru, Nigeria, Bulgaria, the Czech Republic, Hungary, and Poland. All these countries are considered emerging in DGEI (except the Czech Republic which is classified as advanced).

- We classify South Korea and Taiwan as advanced for the DGEI, but these countries are considered emerging in the BoG's foreign exchange value of the dollar index.

\subsection{Pre-processing the Data (at the Country Level) ${ }^{2}$}

Our system of data management for the DGEI is based primarily on an Excel-VBA environment supplemented with E-views 8 code.

- Seasonal adjustment: The program that manages DGEI performs concurrent seasonal adjustment. It takes all the defaults of X12-ARIMA and uses a multiplicative model, unless the series has negative or zero values or is expressed in percent in which case it switches to the additive model.

- Missing data, frequency adjustments:

o Linear interpolation for gaps in the series.

o Temporal disaggregation to adjust the frequency of all the time series to monthly or (for real GDP) quarterly.

- Quadratic-match average method for the indicators. Appendix B. An Assessment of the Quadratic-Match Method for Interpolation includes additional information on the quadratic-match method for data interpolation.

- Constant interpolation for the annual weight data.

- Linear interpolation for the forecasts.

${ }^{2}$ For more details on the country data, see Appendix C. Country Sources. 
- Extending country series backwards (splicing), and other data adjustments:

o DGEI uses the growth rates of the historical series to splice the current series backwards. In some cases, the historical series has to be temporally disaggregated and/or linearly interpolated before it can be spliced together with the most current series.

\subsubsection{Real Economic Activity Indicators}

Real GDP: If the current series does not extend back to the first quarter of 1980 and historical data are available, the two series are spliced together. This affects the series for Austria, Belgium, Italy, Sweden, Canada, Portugal, Spain, Colombia, Nigeria (only back to the first quarter of 1981), and China. All annual data is interpolated to a quarterly frequency-prior to splicing - using the quadratic-match average method.

Industrial Production (IP): Total industrial production excluding construction is our preferred IP series for the DGEI. This measure includes the mining, manufacturing, and utilities sector and has broad cross-country and time series coverage. We exclude the construction sector because it tends to display patterns that are different than those of the other sectors. If the preferred series is not available, manufacturing production is used as a proxy (or total IP if no other alternative is found).

0 If the current series does not extend back to January of 1980 and historical data are available, the two series are spliced together. This is the case for Belgium, Canada, Greece, Chile, Colombia, Peru, Venezuela, Indonesia, Philippines, and Thailand.

o Current data for Switzerland, Australia, and Nigeria are reported at a quarterly frequency. Nigeria's series is also spliced with historical quarterly data to extend the series back to 1980. All quarterly data are interpolated to a monthly frequency-prior to splicingusing the quadratic-match average method.

Purchasing Managers' Index (PMI): The PMIs for most countries refer to the manufacturing sector-the exception being Canada, which is a composite of the manufacturing and service sectors. A manufacturing PMI series is available for Canada, but it does not start until October 2010.

o The PMI series for Australia is reported at a quarterly frequency until May of 2001. Quarterly data reported prior to this date is interpolated to a monthly frequency using the quadratic-match average method.

o Not all countries report PMI data. Those excluded from the aggregate due to lack of data or due to their very short time series are: Belgium, Portugal, Argentina, Chile, Colombia, Costa Rica, Peru, Venezuela, Indonesia (which began reporting in April 2011), Malaysia, Philippines, Thailand, Nigeria, and Bulgaria. ${ }^{3}$ Each PMI aggregate is constructed as a diffusion index and computed as a weighted-average of the PMI indexes available for the G40 countries in DGEI.

\footnotetext{
${ }^{3}$ All countries included in DGEI that have PMI data have series starting by the cutoff year of 2005, except for Turkey, which starts in June 2005, Brazil, which starts in February 2006, and India, which starts in March 2005. These countries' data were included because of their importance to the global economy.
} 


\subsubsection{Price Indicators}

Headline CPI Inflation: If the current series does not extend back to January of 1980 and historical data are available, the two series are spliced together. This affects the U.K. and India.

o Current data for Australia is reported at a quarterly frequency, which is interpolated to a monthly frequency using the quadratic-match average method.

Core CPI Inflation (Excluding Food and Energy): Core CPI is another price indicator that excludes items with volatile prices such as food and energy. Our preferred series when available is the once that excludes both items (food as well as energy). Country series spliced with historical data are those of the U.K., Austria, Belgium, France, Germany, Italy, Netherlands, Sweden, Switzerland, Canada, Greece (only back to January of 1989), Spain, Argentina (only back to January of 1993), India (only back to January of 2006), and Australia.

o Current data for Australia is also reported at a quarterly frequency. All quarterly data is interpolated to a monthly frequency-prior to splicing_using the quadratic-match average method.

Producer Price Index (PPI) / Wholesale Price Index (WPI) Inflation: The DGEI dataset mixes producer prices (PPI) and wholesale prices (WPI), as not all countries report them both. The WPI differs from the PPI because it includes domestically produced goods sold in the home market (also included in the PPI) and imported goods (which are excluded from the PPI). WPI excludes prices of exported goods (which are included in the PPI). WPI also measures purchasers' prices - including transportation costs, sales taxes, and VAT—while PPI measures sellers' prices at the factory. For further reference on the development of the PPI program, see IMF (2004).

o Countries spliced with historical data are France (only back to 1995), South Africa, and Philippines. Countries with incomplete data with no available historical series are Italy and Netherlands (starting in 1981), Turkey, Malaysia and Peru (1986), Portugal (1990), Brazil and Costa Rica (1991), Argentina (1993), Greece and Thailand (1995), Austria (1996), Venezuela (1998), Chile (2003), and Mexico (2003). Current data for Australia (starting in 1998) is reported at a quarterly frequency, which is interpolated to a monthly frequency using the quadratic-match average method. Countries in G40 with no data at all are just one: Nigeria.

o Composition mix of PPI and WPI series in the G40 country sample:

- Countries that report WPI but not PPI are Brazil, Peru, Taiwan, India, and Indonesia.

- If there is a total PPI measure for a country, we use that series; otherwise, we use manufacturing PPI. Countries that report only manufacturing PPI are the U.K., Netherlands, Japan, South Africa, Venezuela, Philippines, and the Czech Republic. For the U.S., we choose the PPI for finished goods. 
Nominal Exchange Rates: All exchange rate data are expressed as US\$/foreign currency. If the current series does not extend back to January of 1980 and historical data are available, the two series are spliced together. This splicing affects Brazil and Peru whose exchange rate is extended back to January of 1990 using historical series.

o For the euro area countries, the US\$/euro exchange rate is used once a country becomes a member. Prior to the date the countries adopted the euro, the exchange rate of the legacy currency with the U.S. dollar is converted to euros using the irrevocable exchange rate. ${ }^{4}$

Real (CPI-based) Exchange Rates: Real exchange rate data is computed by multiplying a country's nominal exchange rate (US\$/foreign currency) by the ratio of that country's headline CPI to the U.S. headline CPI. All CPI series are indexed to 2006=100. This CPI-based construction methodology is similar to that described by Loretan (2005) and more recently by Darvas (2012) among others.

Real (PPI-based) Exchange Rates: Real exchange rate data is computed by multiplying a country's nominal exchange rate (US\$/foreign currency) by the ratio of that country's PPI/WPI to the U.S. PPI. ${ }^{5}$ All PPI/WPI series are indexed to 2006 $=100$. This PPI-based measure is constructed following the same approach as the real (CPI-based) exchange rate described before.

\subsubsection{Trade Indicators}

Merchandise Exports to World and Imports from World: Prior to 1997, trade data for Belgium and Luxembourg was reported jointly. To extract the Belgium portion of the combined trade series, the average ratio of Belgium's trade to the combined Belgium-Luxembourg trade is computed from 1997 to 2007. This ratio is used to estimate Belgium's portion of the combined trade for all years prior to 1997 for which data exclusively for Belgium is not available (prior to 1993). Similar to this, the average ratio of South Africa's imports and exports to total imports and exports for the Southern African Customs Union (SACU) from 1998-2007 is used to extract South Africa's trade share prior to 1998.

\footnotetext{
${ }^{4}$ Legacy currencies of the euro and their rate of conversion are: Austrian schilling (13.7603 since 1999), Belgian franc (40.3399 since 1999), Cypriot pound (0.585274 since 2008), German mark (1.95583 since 1999), Estonian kroon (15.6466 since 2011), Spanish peseta (166.386 since 1999), Finnish markka (5.94573 since 1999), French franc (6.55957 since 1999), Greek drachma (340.75 since 2001), Irish pound (0.787564 since 1999), Italian lira (1,936.27 since 1999), Luxembourgish franc (40.3399 since 1999), Latvian lats (0.702804 since 2014), Monegasque franc (6.55957 since 1999), Maltese lira (0.4293 since 2008), Dutch guilder (2.20371 since 1999), Portuguese escudo (200.482 since 1999), Slovenian tolar (239.64 since 2007), Slovak koruna (30.126 since 2009), Sammarinese lira (1,936.27 since 1999), and Vatican lira (1,936.27 since 1999).

${ }^{5}$ As noted in Loretan (2005): “(t)he set of internationally traded goods may not be well approximated by the baskets of goods purchased by consumers in various countries. In general, producer price indexes tend to be better measures of inflation for gauging changes in real international competitiveness. Unfortunately, producer price indexes are not as widely available as consumer price indexes." It is also the case that the coverage of PPI is less complete across time and across countries than the CPI. We argue, nonetheless, that our combination of WPI and PPI measures in DGEI allows the construction of a real exchange rate that is closer to capturing the real international competitiveness of the dollar than the standard CPI-based measures are.
} 


\subsubsection{Financial Indicators}

Short-term Official/Policy Rates: There are four broad categories of policy or short-term interest rates that we consider for the database including target rates, discount rates, lending/deposit rates, and money market rates. DGEI gives preference to official policy rates in each country, but applies suitable alternatives whenever no official rate exists or the series is incomplete.

o The policy rates may have to be extended backwards, but the levels do not always exactly match with those of the historical series whenever different short-term rates are to be spliced together. We use growth rates of the historical series in that case to extend the policy rates backwards and avoid introducing a level effect in the spliced series.

o Countries that report target rates in DGEI: U.S. (which reports an average range), Switzerland (an upper range), Canada (spliced with money market rate in December of 1992), Japan, Brazil, Mexico (spliced with money market rate in January of 2008), Peru (spliced with the discount rate in September of 2003), and Thailand (spliced with discount rate in May of 2000).

- For the euro area countries, the ECB policy rate is used once a country becomes a member adopting the euro. Prior to the date of the adoption of the euro, the policy rate represents the official rate set by the each country's central bank. The short-term deposit rate is used for France prior to January of 1999. While the policy rate for euro area countries from the ECB starts in 1999, Greece did not join the euro area until 2001, so its historical rate is used through the end of 2000.

- When time series have missing observations, linear interpolation is used to fill in monthly values. This occurs in DGEI for Spain (April of 1984), Sweden (August of 1992), and Belgium (January to May of 1991).

o Countries that report central bank discount rates in DGEI: U.K., Sweden, Turkey (1-week repo rate spliced with overnight borrowing rate in May of 2010), Australia, South Africa, Argentina (spliced with money market rate in June of 2004), Chile, Colombia, ${ }^{6}$ Costa Rica, Taiwan, India (repo rate spliced with discount rate in March of 2000), Indonesia, South Korea (spliced with overnight interbank rate in May of 1999), Malaysia (spliced with overnight interbank rate in April of 2004), Philippines, Nigeria, Bulgaria, Russia, Czech Republic, Hungary, and Poland.

o Countries that report lending rates in DGEI: China (1-yr lending rate), and Venezuela (spliced with discount rate in August of 1996).

Long-term Interest Rates: Our preferred series for long-term interest rates is the 10-year government bond yield. A few countries use data from different maturities: South Africa (3-5 years), Russia (365 days or more), and China (5 years). If the current series does not extend back to the first quarter of 1980 and historical data are available, the two series are spliced together. This affects the series for Turkey, Chile, Peru, Taiwan, the Philippines, Thailand, Bulgaria, and Poland. 5-year bond yields are used to extend the series backwards for Turkey and Bulgaria. Countries with data starting after Jan. 2006 are Brazil (November of 2006), Venezuela (June of 2006), Nigeria (July of 2007), Peru (March of 2006), and Turkey (December of 2006). Argentina, Costa Rica, and Indonesia are not included due to lack of data.

\footnotetext{
${ }^{6}$ Colombia series is extended back to April of 1995 using monthly data obtained from the central bank's website: http://www.banrep.gov.co/series-estadisticas/see_tas_intervencion.htm.
} 


\subsection{Aggregation Methods}

The program that manages the DGEI performs all operations necessary to construct the aggregates and operates primarily through E-views 8. Broadly consistent with the practice of constructing National Accounts followed by most statistical offices and the OECD (2011)'s Economic Outlook methodology, all reported aggregate series are computed on the basis of timevarying, annual weights (this is the so-called chain-linked method). Moving weights are thought to better capture the structural changes that occur in the data over long periods of time (see Figure 6 and Figure 7 for evidence of such structural change).

The weighting schemes used would depend on the variable to be aggregated. Consistent with the standard guidelines adopted by the OECD (2011)'s Economic Outlook methodology, we consider two methods. ${ }^{7}$

- Weighting scheme 1: weights are applied to the variable in levels - to be preferred with diffusion indexes (PMIs) or rates of interest (the official/policy interest rates),

$$
\sum_{i=1}^{N} Y_{t}^{i} w_{t}^{i}, \quad \text { time } t
$$

where $w_{t}^{i}$ is the weight of country $i$ in period $t$ among the $N$ countries to be combined, and $Y_{t}^{i}$ is the variable to be aggregated.

- Weighting scheme $2:^{8}$ weights are applied to the variable in growth rates - to be preferred with indexes (industrial production, core and headline price indexes) or variables expressed in absolute values (real GDP, exports and imports, nominal and real exchange rates),

$$
\sum_{i=1}^{N}\left(Y_{t}^{i} / Y_{t-1}^{i}-1\right) w_{t}^{i}, \quad \text { time } t
$$

where $w_{t}^{i}$ is the weight of country $i$ in period $t$ among the $N$ countries to be combined, and $Y_{t}^{i}$ is the variable to be aggregated. After the weighted average growth rates have been calculated, the resulting series is transformed into an index with a base year of $2005=100$.

\footnotetext{
${ }^{7}$ The use of these two aggregation schemes is consistent with the methodology of the OECD’s Economic Outlook (http://www.oecd.org/eco/outlook/aggregationmethods.htm) and similar to the methodology followed by the IMF in its World Economic Outlook (http://www.imf.org/external/pubs/ft/weo/data/assump.htm, https://www.imf.org/external/pubs/ft/weo/2013/02/pdf/statapp.pdf).

${ }^{8}$ Aggregating variables in levels (weighting scheme 1), the level of the aggregate may change from one year to the next due to changes in the weights even if the country series remained invariant. Aggregating variables in growth rates (weighting scheme 2) does not have this less desirable property, as the aggregate remains invariant when the country series do not change given that the aggregated growth rate would stay at zero even if the weights themselves are changing over time.
} 
The level of the aggregate series can be obtained as follows:

- National Income and Product Account series in levels (real GDP in our case) are PPPadjusted for comparability and then aggregated for the corresponding base year to scale the index derived from the growth rates.

- Select a base year (in our case, 2005). The 2005 quarterly observations for the nominal GDP series in local currency of each country are converted into PPP terms using the implied 2005 PPP conversion rates-obtained from the IMF World Economic Outlook (WEO) Database.

- Aggregate PPP-adjusted real GDP for the base year for all countries in the group. The index series obtained from the aggregated growth rates is then rescaled with that measure.

- The rescaling factor for other variables computed as an index using weighted growth rates is obtained by adding up the levels of the variable across all countries in the corresponding grouping for the base year.

Consistency and representativeness of the aggregates is also a matter of concern in the construction of DGEI. We impose the rule that group aggregates are calculated (and reported) only if countries for which data is available represent 80 percent or more of the group weight. This rule is also used to determine when the most recent observations can be included in the time series. ${ }^{9}$

The underlying country data are released with varying lags and are subject to data revisions. One of our objectives is to make available the DGEI indicators each month/quarter in a timely fashion whenever data is available for countries representing 80 percent or more of those included in each grouping. Consequently, our aggregate series are calculated without observations for some countries which are reweighted out.

o In subsequent updates when these missing country observations become available, correcting the initial series becomes a source of revisions in DGEI.

0 The country series themselves are systematically revised by the original reporting sources which becomes another source of revisions in DGEI.

0 The weighting data is revised as well by the original reporting sources, affecting the DGEI indicators as well.

However, we notice that among all these sources of revisions, the ones from weight data tend to be less frequent and produce small changes on the aggregates than the other two.

\footnotetext{
${ }^{9}$ This is a slightly less strict rule than the one used by the IMF in its World Economic Outlook (WEO) where "country group composites represent calculations based on 90 percent or more of the weighted group data." For more details, see: http://www.imf.org/external/pubs/ft/weo/data/assump.htm
} 


\subsection{Exact Growth Rate Formulas}

A convention that is sometimes useful is to compute log-differences, as those are approximations to the growth rates of the series which have the property of being additive-the log-difference between two periods must be equal to the sum of the log-differences between any number of subperiods on which the time elapsed can be split. ${ }^{10}$ However, unless otherwise noted, we always use the exact formula of the growth rates to compute average growth for aggregation purposes (as described in weighting scheme 2) and to report the growth rates of the aggregated series.

The exact growth rate formulas that we use are:

- The rate of growth of a variable $Y_{t}^{i}$ for country $i$ in period $t$ over the preceding period $t-1$ expressed in percentage terms is computed as follows,

$$
100\left(Y_{t}^{i} / Y_{t-1}^{i}-1\right)
$$

while the growth rate is reported in annualized terms using the following formula,

$$
100\left(\left(Y_{t}^{i} / Y_{t-1}^{i}\right)^{s}-1\right)
$$

where $s$ defines the periodicity ( $\mathrm{s}=4$ for quarterly data, $\mathrm{s}=12$ for monthly).

- The year-on-year growth of a variable $Y_{t}^{i}$ for country $i$ in period $t$ over the preceding period $t$-s of the previous year expressed in percentage terms is computed as follows,

$$
100\left(Y_{t}^{i} / Y_{t-s}^{i}-1\right)
$$

where here again $s$ defines the periodicity ( $s=4$ for quarterly data, $s=12$ for monthly).

\footnotetext{
${ }^{10}$ The IMF uses, for instance, a combination of log-differences and exact growth rates in some cases (especially for emerging countries) as can be seen here: http://www.imf.org/external/pubs/ft/weo/faq.htm. While the OECD uses exact growth rates only: http://www.oecd.org/eco/outlook/growthratesineodb.htm.
} 


\subsection{Aggregation Weights}

The choice of weights used for aggregation purposes depends on the particular nature of the variables to be aggregated and on the economic interpretation assigned to the aggregated series. The OECD, IMF, and other international organizations all apply different weights to their aggregates and use different approaches depending on whether the variables are reported as ratios, as diffusion indexes, in levels, etc. We give preference to trade weights with the U.S. in weighting the variables in DGEI, but allow for a number of automated alternative aggregation schemes in order to provide additional flexibility to the system of data management underlying the database.

We favor trade weights with the U.S. because of a number of economic reasons. First, because of the domestic spill-overs from global economic factors that come through trade (e.g., global slack hypothesis as in Martínez-García and Wynne (2010)). Second, because it is sensitive to differences in business cycle synchronization (see, e.g., Martínez-García and Søndergaard (2009)). When foreign countries experience high growth, the demand for imported goods from the home country increases, favoring positive business cycle correlations by stimulating domestic growth; in turn, if growth prospects are better abroad than at home, there is an incentive to invest overseas where capital is more efficient and reduce production at home which leads to negative business cycle correlations - which of these two effects dominates depends, among other things, on the degree of financial and trade openness.

An alternative approach to country weighting is based on the foreign exchange value of the dollar implemented by the Board of Governors (BoG). Loretan (2005) describes the construction of trade weights corrected by trade in undifferentiated goods and adjusted by competitiveness. The theoretical basis for the weights of the BoG's index is derived from a stylized model of international trade which suggests that only trade in differentiated products is affected by exchange rate fluctuations (see, e.g., McGuirk (1986)). This model implies that all international trade in undifferentiated goods (such as trade of primary commodities) should be excluded. While the BoG's index follows that recommendation to compute its foreign value of the dollar index, DGEI aggregates many other indicators for which there is no clear model prediction. We adopt a standard trade weight that does not correct for trade in primary commodities or undifferentiated goods, but we apply it consistently to all indicators included in the database.

The weights of the BoG's index are also corrected to give a large competitive weight-adjustment to a country if it is a large contributor of exports to other countries that also receive a large portion of U.S. exports. The BoG refers to this adjustment as the U.S. third-market competitiveness weight of economy $j$. "(I)t can be interpreted as a weighted average of $j$ 's bilateral shares of the third-market economies' imports, where the weights are given by those economies' U.S. bilateral export shares," as indicated in Loretan (2005). We do not attempt a similar competitive weight correction at this stage. Instead, based on the implications of standard New Open Economy Macro models (see, e.g., Martínez-García and Søndergaard (2009)), we consider import shares as an alternative to trade weights or trade weights corrected by competitiveness. 
i. Annual weights for trade-weighted aggregation

$$
w_{t, k}=\frac{\text { imports }_{t, k}+\text { exports }_{t, k}}{\sum_{k=1}^{N}\left(\text { imports }_{t, k}+\text { exports }_{t, k}\right)}, \quad \text { country } k
$$

Weights are calculated in nominal terms quoted in U.S. dollars. There are two variants: world trade shares and shares of trade with the U.S. Trade shares with the U.S. is our current default.

Trade weights put more emphasis on the role of trade competition, assigning a larger share to countries that are more engaged in trade with the U.S.

a. World and U.S. annual trade weights are from the IMF's Direction of Trade (DOT) database and represent annual exports and imports with the world/U.S. originally in millions of U.S. dollars. Weights are fixed throughout each year, but vary across years.

b. Adjustments to the data:

- IMF's DOT does not report on Taiwan whose data come from the Ministry of Finance of the Republic of China.

- Prior to 1997, Belgian values also include Luxembourg trade data. To extract the Belgium portion of the combined trade, the average ratio of Belgium's trade to the combined Belgium-Luxembourg trade is computed from 1997 to 2007. This ratio is used to estimate Belgium's portion of the combined trade for all years prior to 1997.

c. Missing observations:

- World and U.S. trade shares: Bulgaria and Nigeria start in 1981, Russia starts in 1992, Czech Republic starts in 1993.

ii. Annual weights for the GDP-weighted aggregation

$$
w_{t, k}=\frac{G D P_{t, k}}{\sum_{k=1}^{N} G D P_{t, k}}, \quad \text { country } k
$$

Weights are calculated in nominal terms quoted in U.S. dollars and in PPP-adjusted terms. As a result, there are two variants in DGEI based on PPP-adjusted GDP shares and nominal shares in U.S. dollars.

GDP weights put more emphasis on the economic size of a country, assigning a larger share to countries whose economy accounts for a larger fraction of world output.

a. Data for the PPP-adjusted GDP weights comes from the IMF's World Economic Outlook (WEO). Data for the nominal weights comes from the IMF's World Economic Outlook (WEO) as well, quoted in billions of U.S. dollars at market exchange rates (whenever available).

b. Missing observations on PPP-adjusted and nominal GDP shares: Russia starts in 1992, Czech Republic starts in 1995. 
Adjustment for missing weight data: For years for which we do not have weight data, we compute the weights of the reporting countries with the available data and re-scale them to adjust for the weight of the missing countries. To do so, we multiply the series with the factor (1 $\left.\sum_{k=1}^{p} \bar{w}_{t, k}\right)$, where $p$ are the countries without weight data prior to time $t$ and $\bar{w}_{t, k}$ refers to the weight that any given of those countries $k=1, \ldots, p$ has whenever it enters for the first time into the sample in period $t$.

\subsection{Unbalanced Datasets}

In spite of our attempts to standardize the time series for the DGEI and extend them back in time whenever possible, data availability remains an issue — especially in the 1980s and early 1990sas illustrated in Figure 9 and Figure 10. The relative importance of the missing observations also varies depending on the variables of interest—with PMIs and official/policy rates being the ones with the largest data gaps, and long-term interest rates requiring the splicing of bond yields of somewhat varying long maturities to extend the short reported time series. In spite of that, the G40 country composition in DGEI still suffices to capture and incorporate in our aggregates the broad structural trends observed in the data since 1980. First, it accounts for the fact that the share of U.S. trade from emerging countries has increased substantially to a point where it has become "quite close" to the share from advanced countries (referring to advanced countries other than the U.S.). Secondly, it also incorporates the fact that the emerging economies' share of world GDP in PPP-adjusted terms has surpassed that of the advanced countries (excluding the U.S.).

The program that manages DGEI performs all operations necessary to splice the series to account for changes in the country composition over time based primarily on E-views 8 code. The system adjusts for shifts that occur due to changes in the country sample, as data for the G40 countries becomes available at different points in time. To correct for jumps that occur due to countries entering the sample, we follow this simple procedure: say country $k$ enters into the sample at time $t$, then the aggregate series calculated without country $k$ is spliced together with the aggregate series calculated with the country included at time $t$ when the country enters into the sample for the first time.

The implementation of that correction in DGEI can be described in the following steps:

- Data becomes available for country $k$ at time $t$.

- An aggregate is then calculated where country $k$ is included from $t$ onwards. Another aggregate is calculated where country $k$ is excluded.

- The two aggregate series are spliced together using the growth rates of the aggregate excluding $k$ to extend the aggregate including $k$ backwards-in order to extend the aggregate with the largest country sample prior to time $t$. 
Figure 9. U.S. Trade Shares Accounted for by G40 Countries (1980-2012)
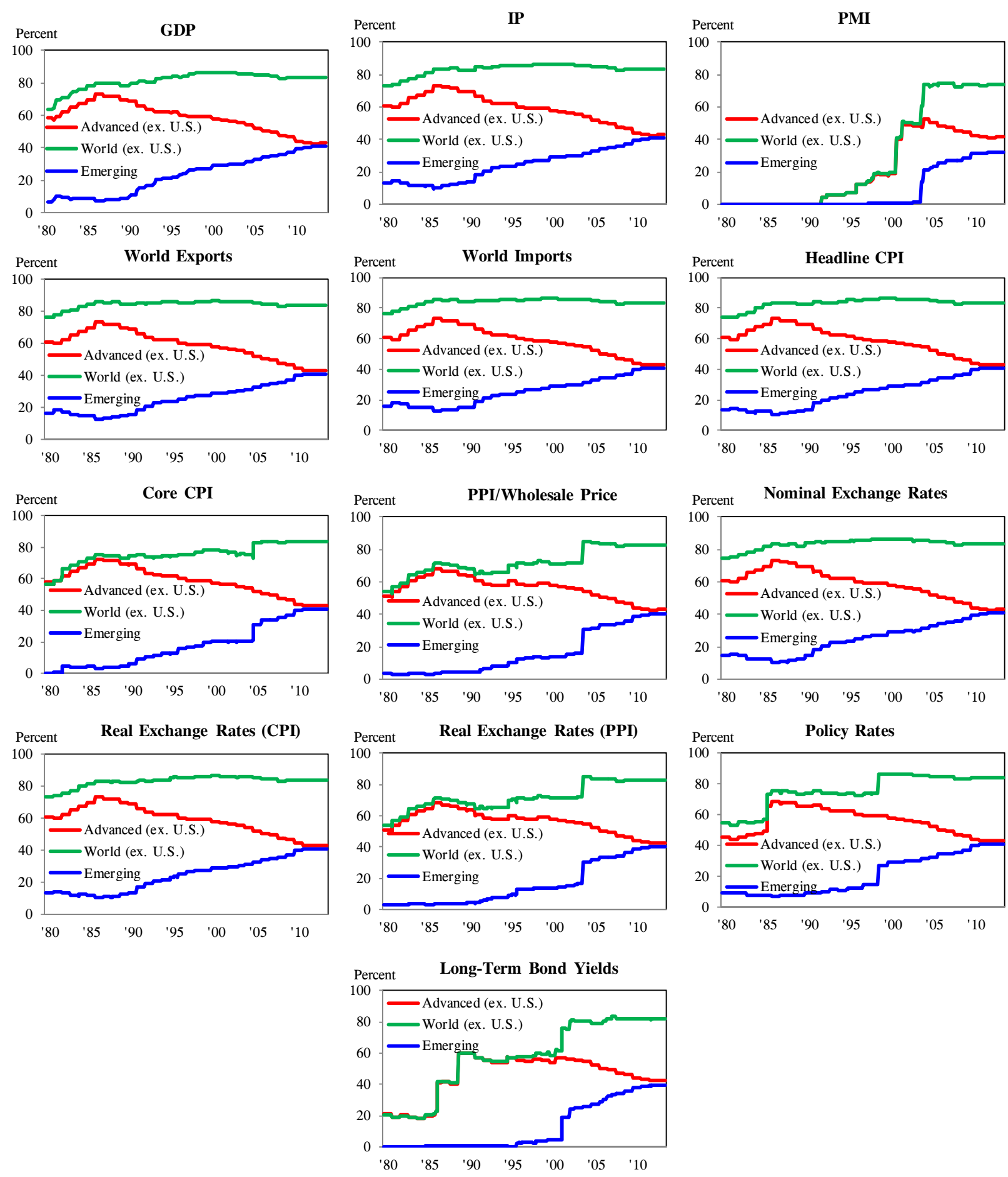

Source: Trade data comes from the IMF Direction of Trade (DOT) database. 
Figure 10. Shares of World GDP (PPP) Accounted for by G40 Countries (1980-2012)
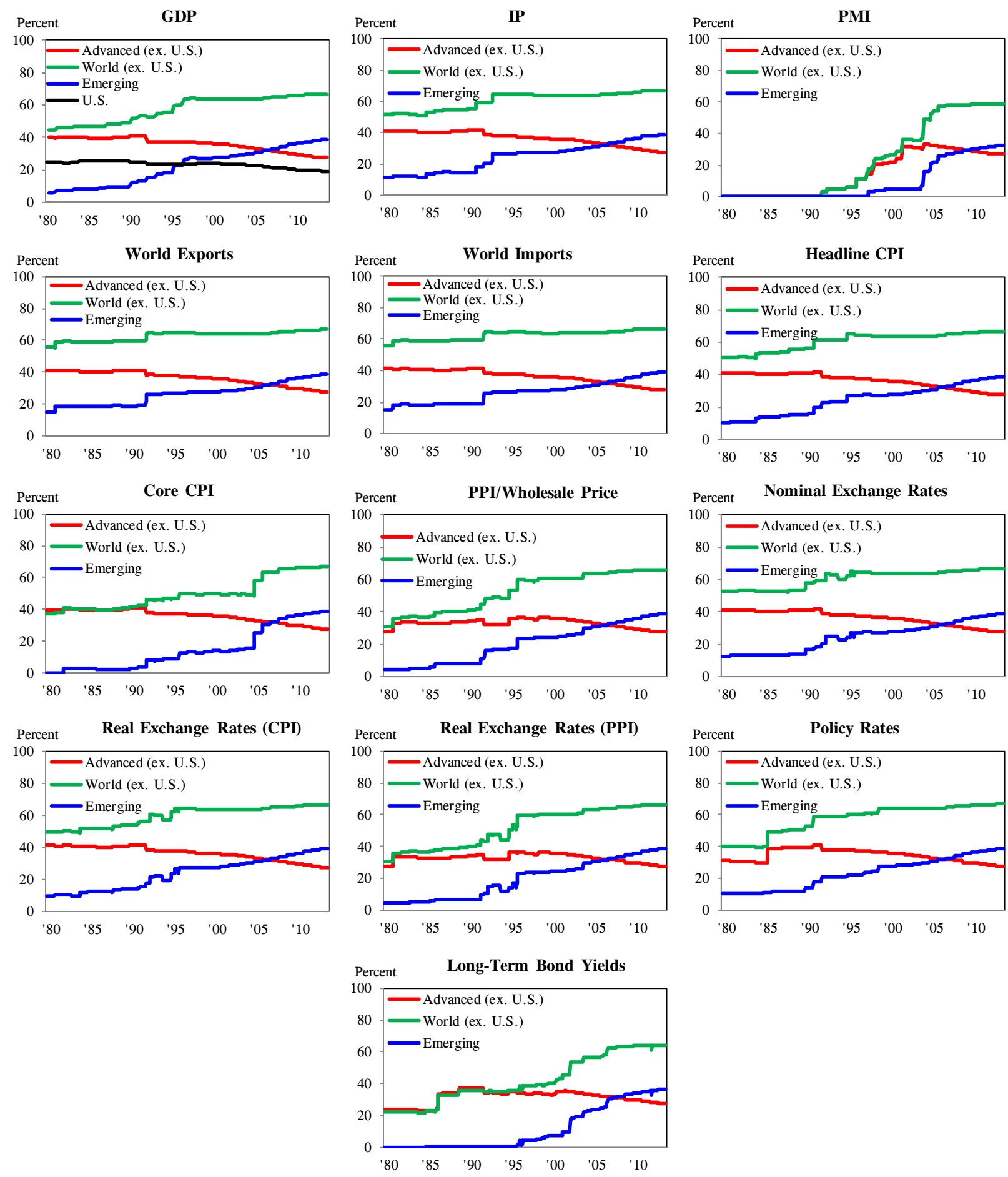

Source: PPP-adjusted GDP shares are from the IMF World Economic Outlook (WEO) database. 


\subsection{Forecasts}

The forecasts available for each country may be reported at different frequencies and with different growth definitions. In that case, the forecasts themselves need to be transformed in order to put them on a common footing before they can be aggregated for the countries in the DGEI sample. The Excel-VBA environment developed for DGEI handles the frequency and growth definition transformations of forecast data for each country to produce consistent aggregates whenever needed.

For most countries, we can obtain or produce quarterly forecasts of year-on-year real GDP growth and CPI inflation. For some countries, only annual forecasts may be available and, therefore, those forecasts require some form of temporal disaggregation. Generally, the annual forecasts on real GDP growth that we have to contend with are for annual growth; the annual forecasts for CPI inflation are often based on annual average levels, but there are cases where the forecasts are December-to-December changes (which we treat as end-of-quarter changes) as well.

The forecasts may also be based on data that is not seasonally adjusted. The procedure implemented in DGEI not only serves for temporal disaggregation, but also to smooth out the resulting series in order to remove seasonality effects as best as possible. A number of procedures have been used in major statistical agencies for the temporal disaggregation and smoothing of time series. DGEI implements a simple approach that performs well with the real GDP and headline CPI series that we track in the database.

The forecasts that we are most interested in cover the horizon over the next two years, but we do not have additional input sources to facilitate the temporal disaggregation of the data. Under these constraints, we adopt the first-difference smoothing method developed by Boot, Feibes, and Lisman (1967) for the DGEI over a range of three years-with the first year fully overlapping with current data. Apart from the obvious simplicity of the procedure, this technique has been used by the Bureau of Economic Analysis (BEA) and shown to work well when no other related series of higher frequency is available to interpolate observed annual data (see, e.g., Chen and Andrews (2008) on this particular point). 
- Forecasts expressed in the form of annual growth rates are used to extend the current (non-seasonally-adjusted) GDP and CPI series forward. This produces a vector of three annual observations (i.e., $\mathrm{Y}_{\mathrm{t}}, \mathrm{Y}_{\mathrm{t}+1}, \mathrm{Y}_{\mathrm{t}+2}$ ), where $t$ corresponds to the last full year of the current sample while $t+1$ and $t+2$ refer to the yearly values implied by the forecasts.

- The solution to the Boot, Feibes, and Lisman (1967) first-difference smoothing method when three years of annual data are involved (i.e., $\mathrm{Y}_{\mathrm{t}}, \mathrm{Y}_{\mathrm{t}+1}, \mathrm{Y}_{\mathrm{t}+2}$ ) produces 12 quarterly observations (i.e., $\mathrm{Y}_{\mathrm{i}, 1}, \mathrm{Y}_{\mathrm{i}, 2}, \mathrm{Y}_{\mathrm{i}, 3}, \mathrm{Y}_{\mathrm{i}, 4}$ for $i=t, t+1, t+2$ ) according to the following formula:

$$
\left(\begin{array}{l}
Y_{t, 1} \\
Y_{t, 2} \\
Y_{t, 3} \\
Y_{t, 4} \\
Y_{t+1,1} \\
Y_{t+1,2} \\
Y_{t+1,3} \\
Y_{t+1,4} \\
Y_{t+2,1} \\
Y_{t+2,2} \\
Y_{t+2,3} \\
Y_{t+2,4}
\end{array}\right)=\frac{1}{1836}\left[\begin{array}{ccc}
569 & -135 & 25 \\
525 & -81 & 15 \\
437 & 27 & -5 \\
305 & 189 & -35 \\
129 & 405 & -75 \\
7 & 513 & -61 \\
-61 & 513 & 7 \\
-75 & 405 & 129 \\
-35 & 189 & 305 \\
-5 & 27 & 437 \\
15 & -81 & 525 \\
25 & -135 & 569
\end{array}\right]\left(\begin{array}{l}
Y_{t} \\
Y_{t+1} \\
Y_{t+2}
\end{array}\right) .
$$

Of these 12 observations, we discard the ones that overlap with currently available data. The temporal disaggregation implemented with this procedure assumes that the quarterly observations must add up to the annual value that is actually observed.

o For CPI data in particular, we must adjust the procedure for some countries in order to recognize that the country series do not add up to the yearly value, but correspond to the average instead. Moreover, for a few others we also have to adjust the transformation in order to reflect that the yearly observations correspond to an end-ofperiod value. All quarterly observations are then linearly interpolated to monthly frequency by assigning the corresponding value of the series to the last month of the quarter (end-of-period).

- Aggregation is implemented for the quarters for which there is no actual data (just the forecasts) with the fixed weights corresponding to the last year of data available.

Observations on the implementation of the Boot, Feibes, and Lisman (1967) procedure: The procedure implicitly abstracts from the seasonality that may exist in the data and is, therefore, combined with seasonally-adjusted historical data. We do not attempt to adjust the series further when some new quarterly data becomes available if the forecasts remain unchanged-we merely replace the disaggregated forecast with the actual seasonally adjusted number. 


\section{Dating the Global Cycle}

Classical business cycles were extensively analyzed by Arthur Burns and Wesley Mitchell in their classic 1946 book "Measuring Business Cycles." The key insight of their work is that many economic indicators co-move along the business cycle, so expansions and contractions are signaled and can be identified by their different impact on a cross-section of indicators. Burns and Mitchell defined a classical recession as a sustained period when a broad range of economic variables falls in the following terms,

"Business cycles are a type of fluctuation found in the aggregate economic activity of nations that organize their work mainly in business enterprises: a cycle consists of expansions occurring at about the same time in many economic activities, followed by similarly general recessions, contractions, and revivals which merge into the expansion phase of the next cycle; this sequence of changes is recurrent but not periodic; in duration business cycles vary from more than one year to ten or twelve years; they are not divisible into shorter cycles of similar character with amplitude approximately their own.” Burns and Mitchell (1946).

We use a similar idea to describe global cycles in DGEI (see Grossman, Mack, and MartínezGarcía (2014)). Rather than using multiple indicators, we exploit the cross-section of one particular indicator that is available for a broad range of countries. We adopt in the DGEI an indicator of the cross-country occurrence of contractions in industrial production (IP) to date global cycles. The indicator is constructed applying the Bry and Boschan (1971) method-in the version of Harding and Pagan (2002) - to a sample of 84 countries representing more than 96 percent of world output (as of 2005).

- Recession dates for the referenced variable are estimated by the Bry-Boschan algorithm: Bry and Boschan (1971), Harding and Pagan (2002).

- Censoring Rules:

1. Turn-phase is 5 months on either side.

2. The minimum length of phase is 4 months.

3. The minimum length of a full cycle is 12 months.

- Dating of global recession is based on a weighted diffusion index

- For each period, calculates a weighted percentage of the countries in recession

- At least $60 \%$ of countries must be in recession

- Applications of similar diffusion indexes found in Artis, Marcellino, and Proietti (2004), Crone (2006), Stock and Watson (2010).

$$
D_{t}=\sum_{i=1}^{N} \omega_{i t} S_{i t} \quad \sum_{i=1}^{N} \omega_{i t}=1
$$

- Turning points for global recessions are defined as periods when IP contraction is widespread around the world. Effectively, we declare that a global recession has occured when the number of countries simultaneously experiencing an IP contraction represent at least 60 percent of world output as measured by PPPadjusted GDP over at least three consecutive months. 
Dating turning points of the global business cycle is done from a global rather than a U.S. perspective. All countries in G40 are included for the determination of global cycles-although the country sample is further broadened in this particular case to incorporate as much information as possible. Country IP data is updated in our Excel-VBA environment, while the indicator of contractions to determine turning points is computed with Matlab code. An illustration of the indicator with our standard country groupings (advanced (ex. the U.S.) versus emerging, and open economies versus closed economies (ex. the U.S.)) can be found in Figure 11, while the implied global recession dates since 1980 are listed in Table 5 below.

Table 5. Global and U.S. Recessions (1980-2012)

\begin{tabular}{lll}
\hline \multicolumn{2}{c}{ Global Recession } & U.S. Recession (NBER) \\
\hline \multirow{21980s}{*}{ 1990s } & February 1980(I)-July 1980(III) & January 1980(I)-July 1980(III) \\
& November 1981(IV)-October 1982(IV) & July 1981(III)-November 1982(IV) \\
2000s & January 1991(I)-March 1991(I)* & July 1990(III)-March 1991(I) \\
& December 2000(IV)-November 2001(IV) & March 2001(I)-November 2001(IV) \\
& February 2003(I)-May 2003(II)* & \\
& February 2008(I)-April 2009(II) & December 2007(IV)-June 2009(II) \\
\hline
\end{tabular}

Note: The U.S. recessions are dated by the NBER. The global recessions are dated using an indicator of the incidence of IP contractions and data from the DGEI database - Haver Analytics (see Grossman, Mack, and Martínez-García (2014)). The asterisk denotes short-lived global recessions of at most four months which are ultimately not considered as recessions in Grossman, Mack, and Martínez-García (2014).

Figure 11. Date-stamping the Global Cycle (1980-2012)

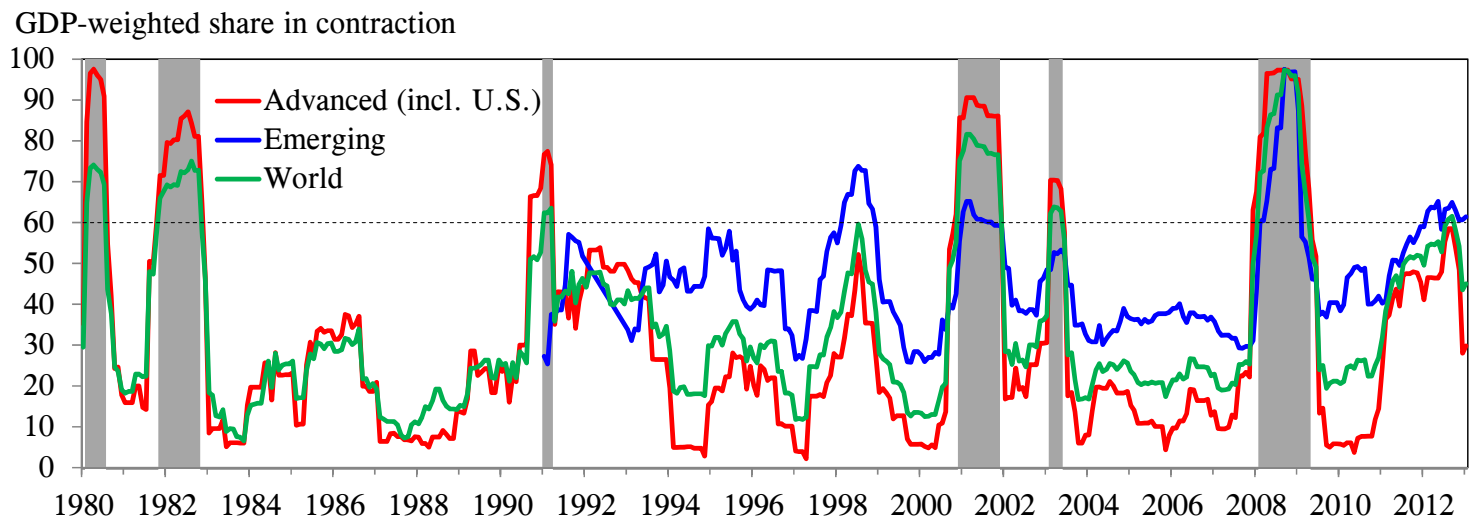

GDP-weighted share in contraction

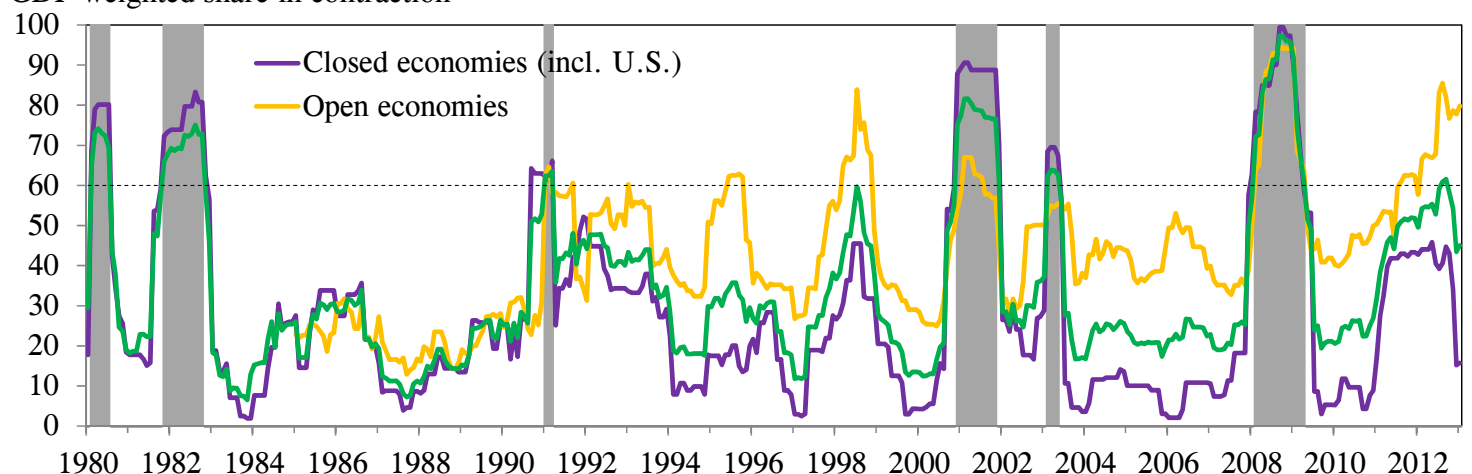

Note: The shaded areas represent global recessions. The indicator of contraction periods in industrial production (IP) is weighted with time-varying PPP-adjusted GDP shares. 


\section{The Database of Global Economic Indicators (DGEI): Summary}

For illustration purposes, the following selection of figures-Figure 12 through Figure 25covering the period from 1999 until 2013 show the series currently available under the DGEI system: 


\subsection{Real Economic Activity Indicators}

\section{Figure 12. Real GDP Growth}

\section{G40 Output Growth}

Real GDP

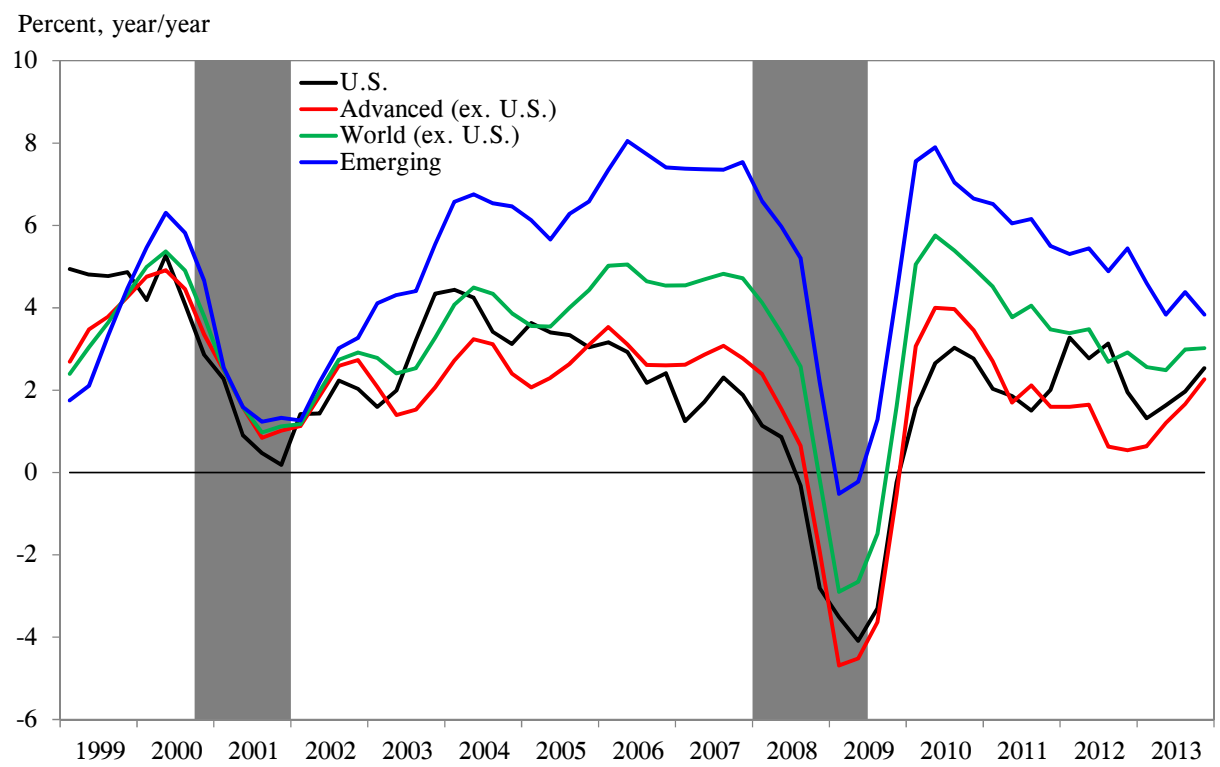

Note: Aggregated using U.S. trade weights. Shaded bars indicate global recessions (Grossman et al. 2014).

\section{G40 Output Growth}

Real GDP

Percent, year/year

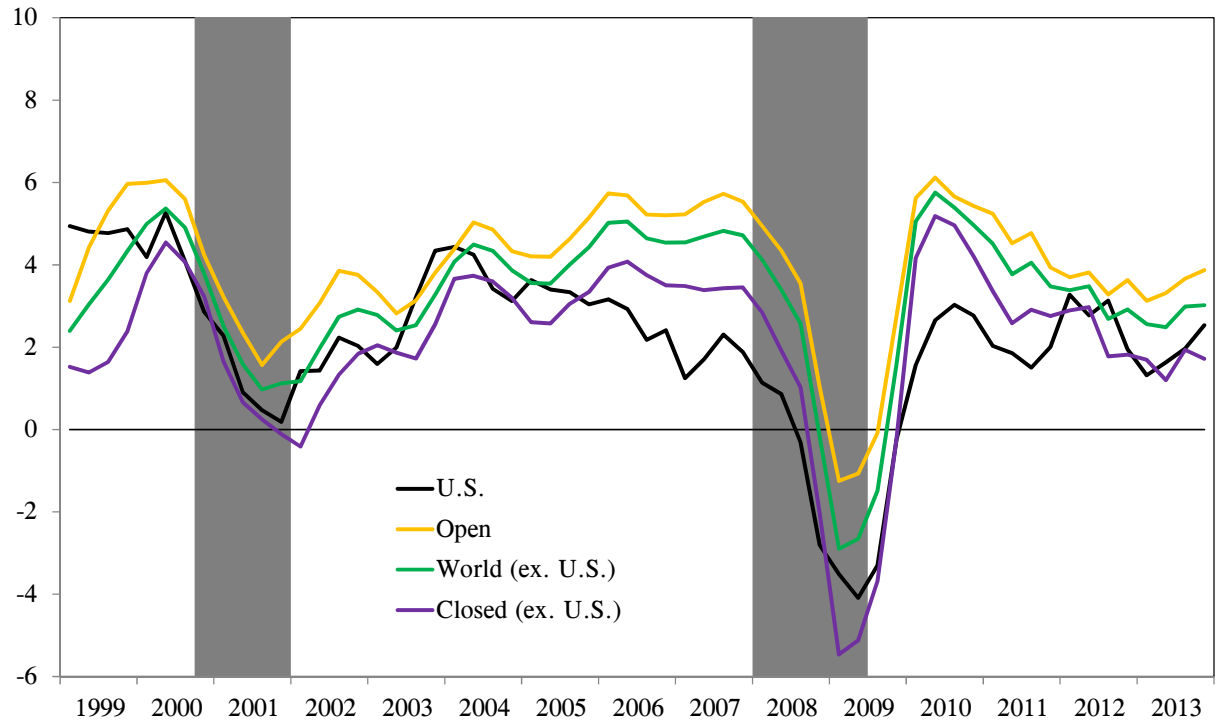

Note: Aggregated using U.S. trade weights. Shaded bars indicate global recessions (Grossman et al. 2014). 


\section{Figure 13. Industrial Production}

\section{G40 IP Index}

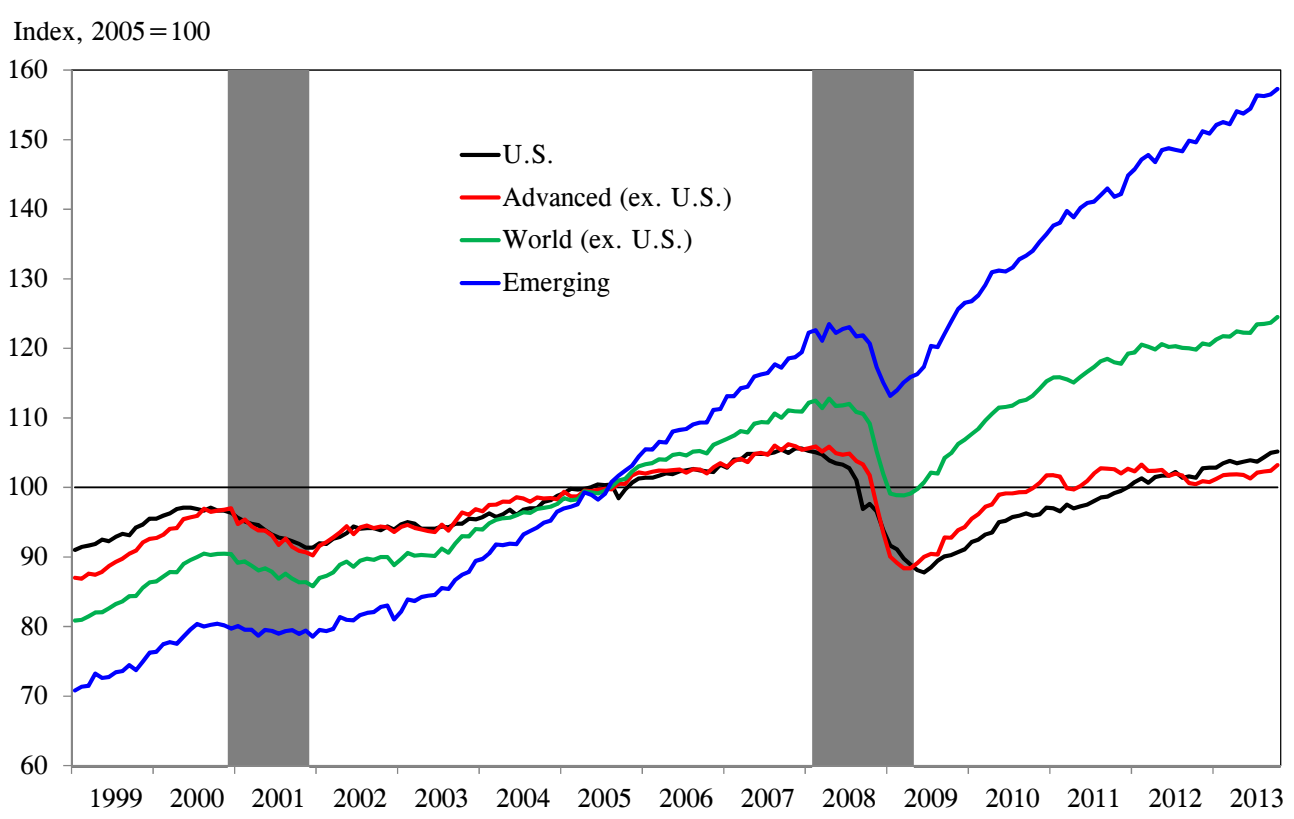

Note: Aggregated using U.S. trade weights. Shaded bars indicate global recessions (Grossman et al. 2014).

\section{G40 IP Index}

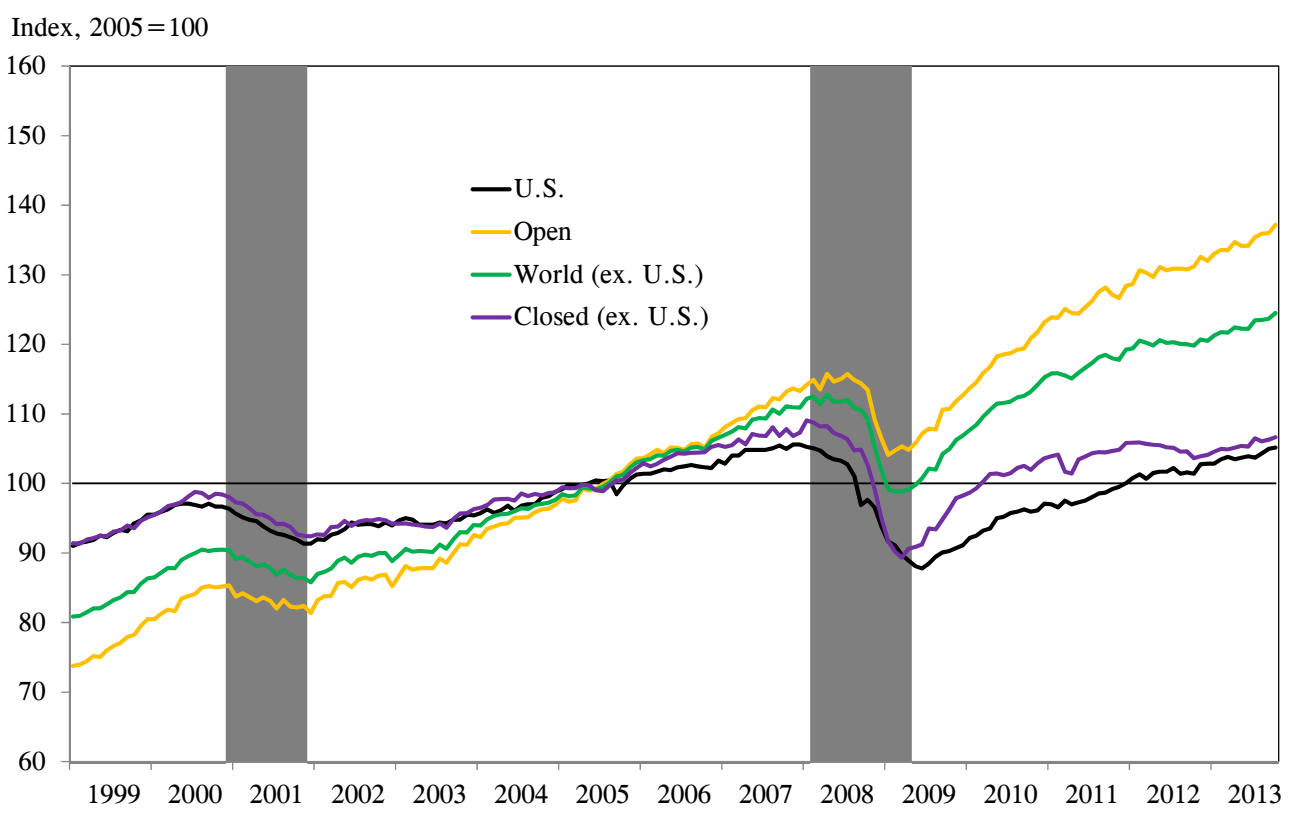

Note: Aggregated using U.S. trade weights. Shaded bars indicate global recessions (Grossman et al. 2014). 


\section{Figure 14. Industrial Production Growth}

\section{G40 IP Growth}

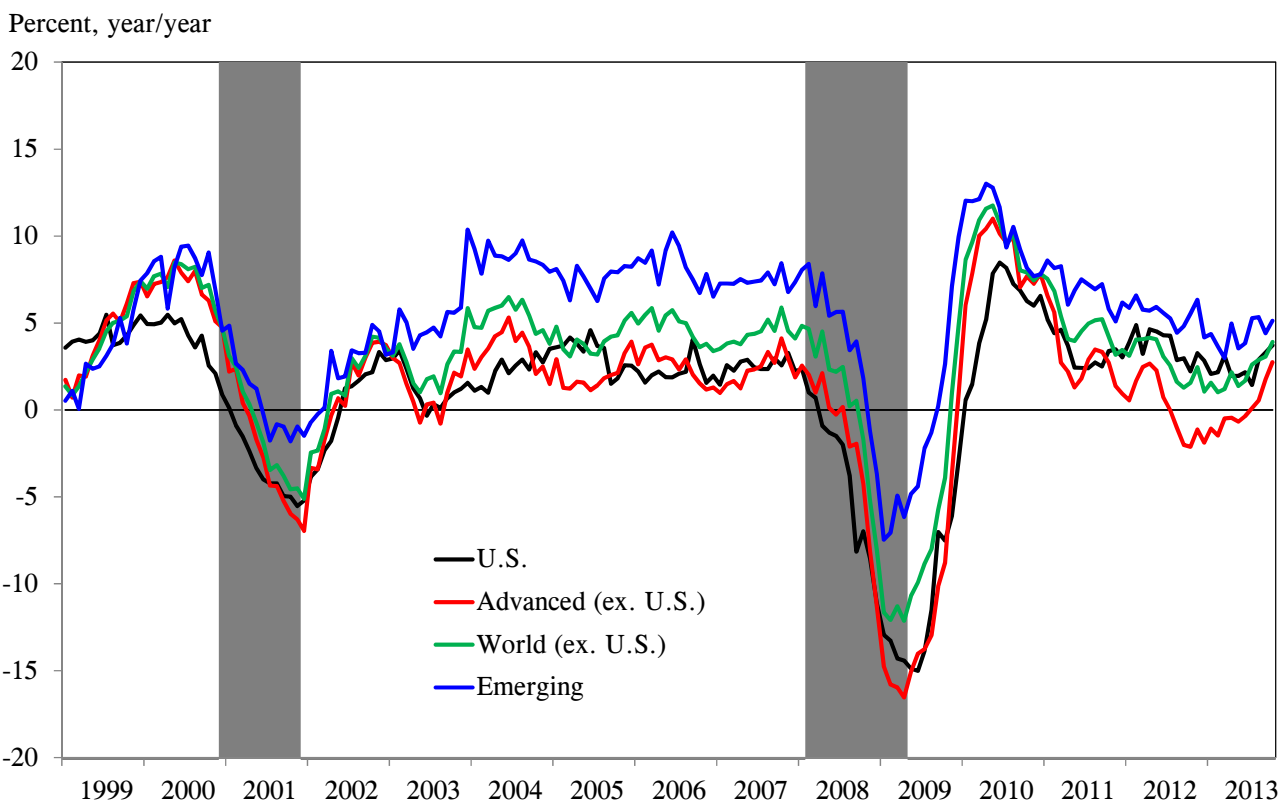

Note: Aggregated using U.S. trade weights. Shaded bars indicate global recessions (Grossman et al. 2014).

\section{G40 IP Growth}

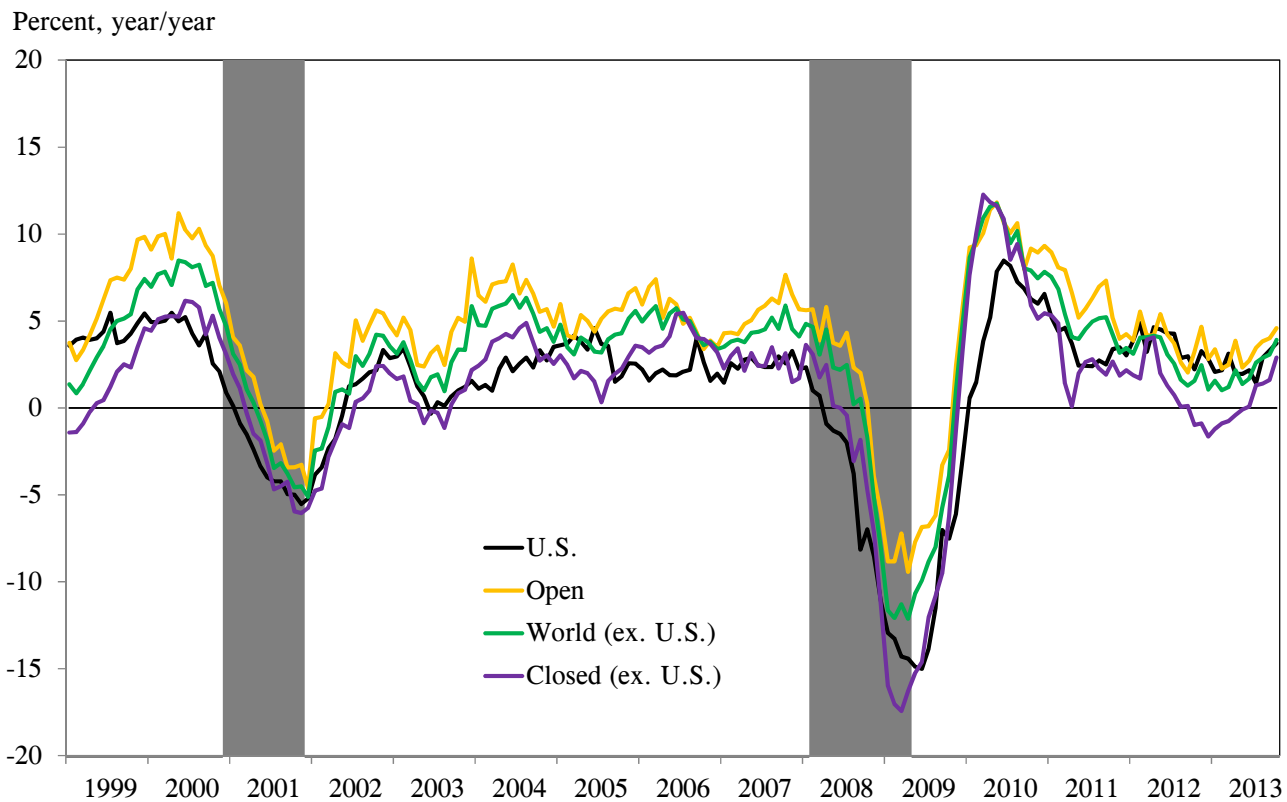

Note: Aggregated using U.S. trade weights. Shaded bars indicate global recessions (Grossman et al. 2014). 
Figure 15. PMI Index

G40 PMI Index

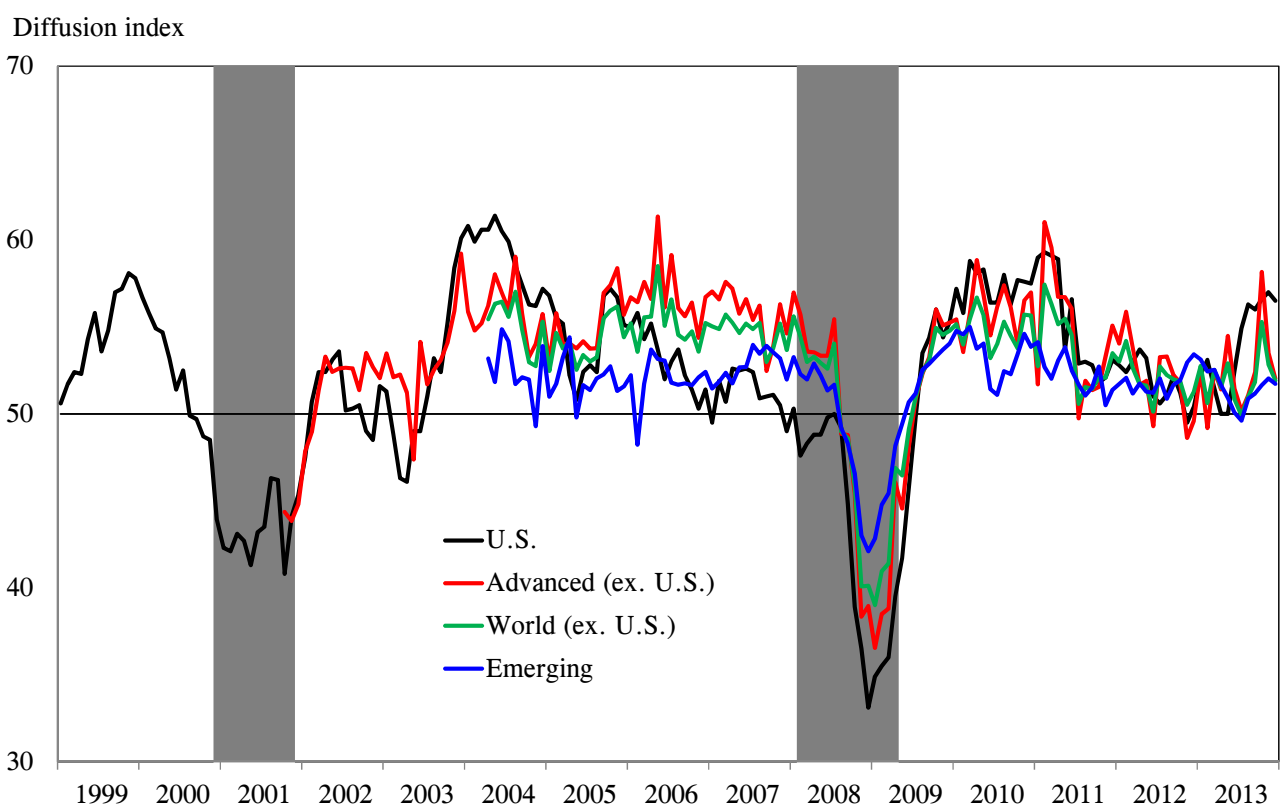

Note: Aggregated using U.S. trade weights. Shaded bars indicate global recessions (Grossman et al. 2014).

\section{G40 PMI Index}

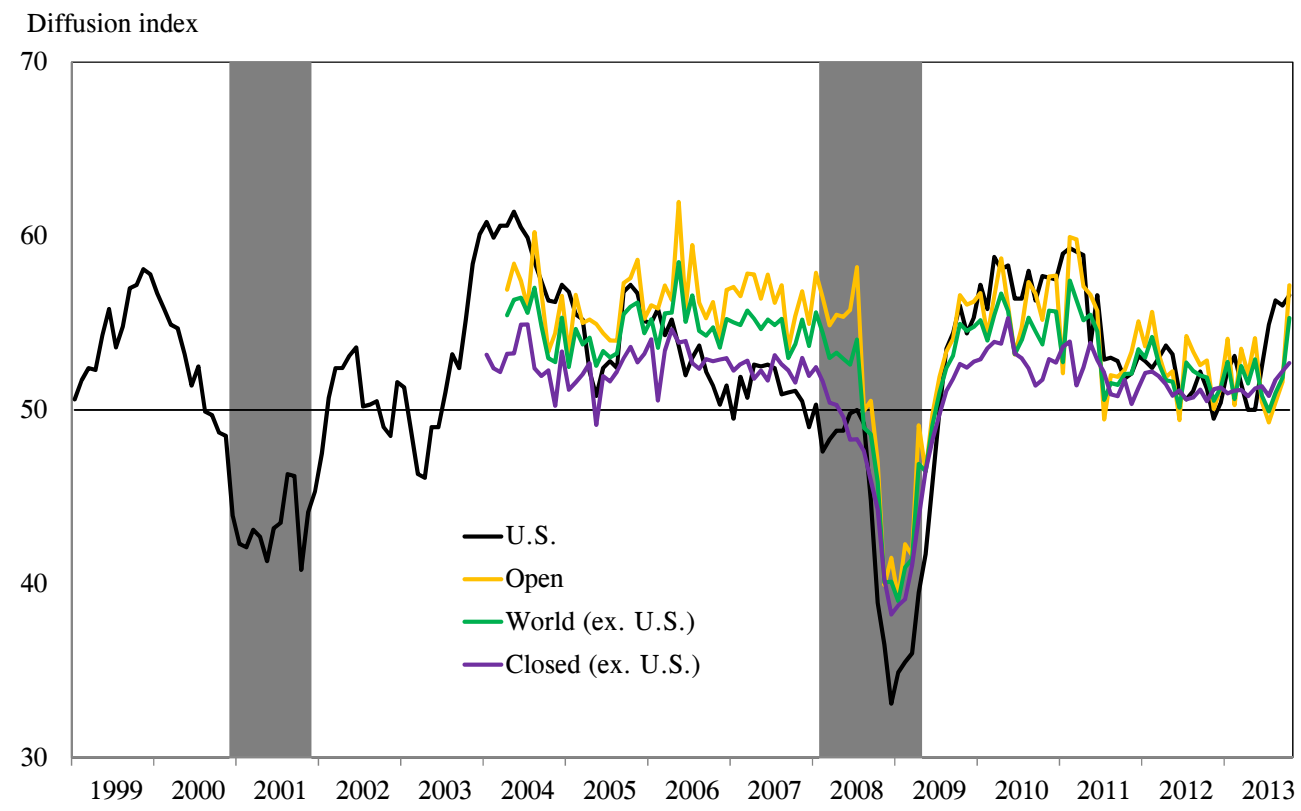

Note: Aggregated using U.S. trade weights. Shaded bars indicate global recessions (Grossman et al. 2014). 


\subsection{Price Indicators}

\section{Figure 16. Headline CPI Inflation}

\section{G40 Headline Inflation}

Headline CPI

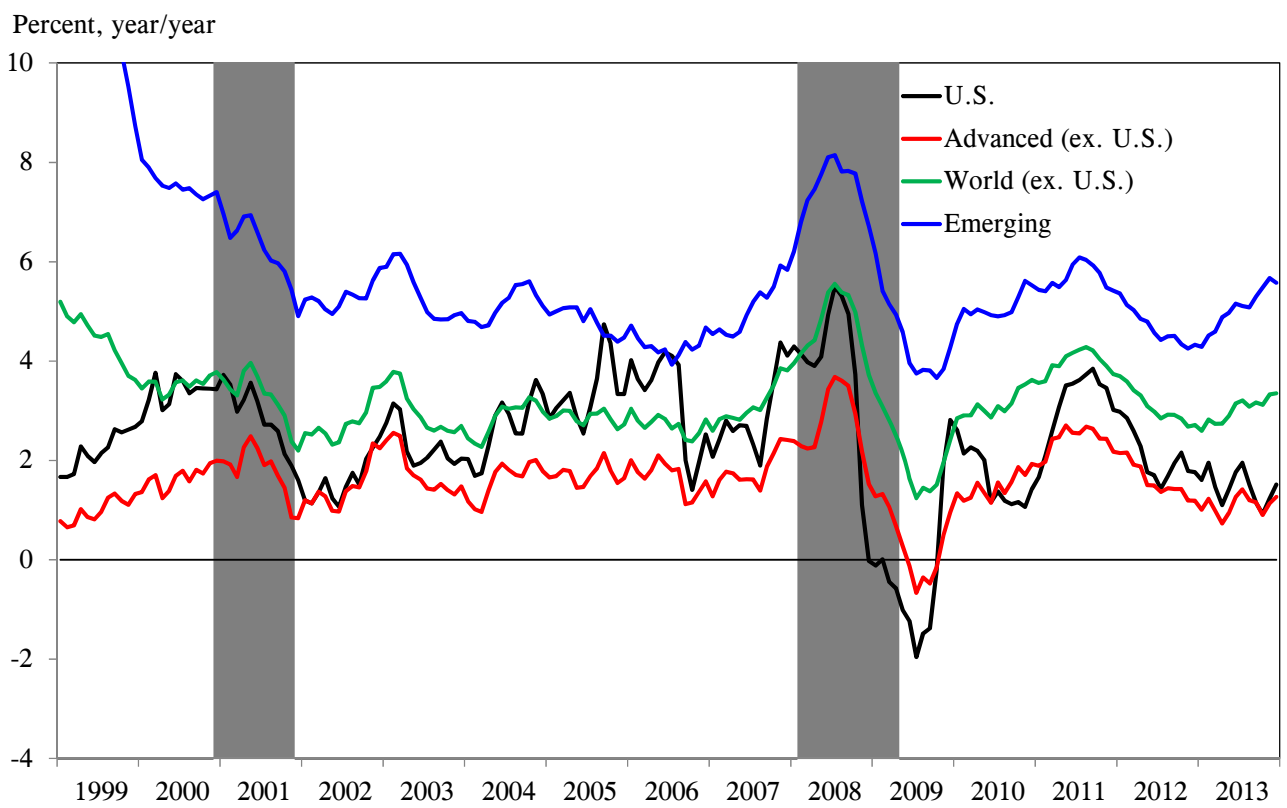

Note: Aggregated using U.S. trade weights. Shaded bars indicate global recessions (Grossman et al. 2014).

\section{G40 Headline Inflation}

Headline CPI

Percent, year/year

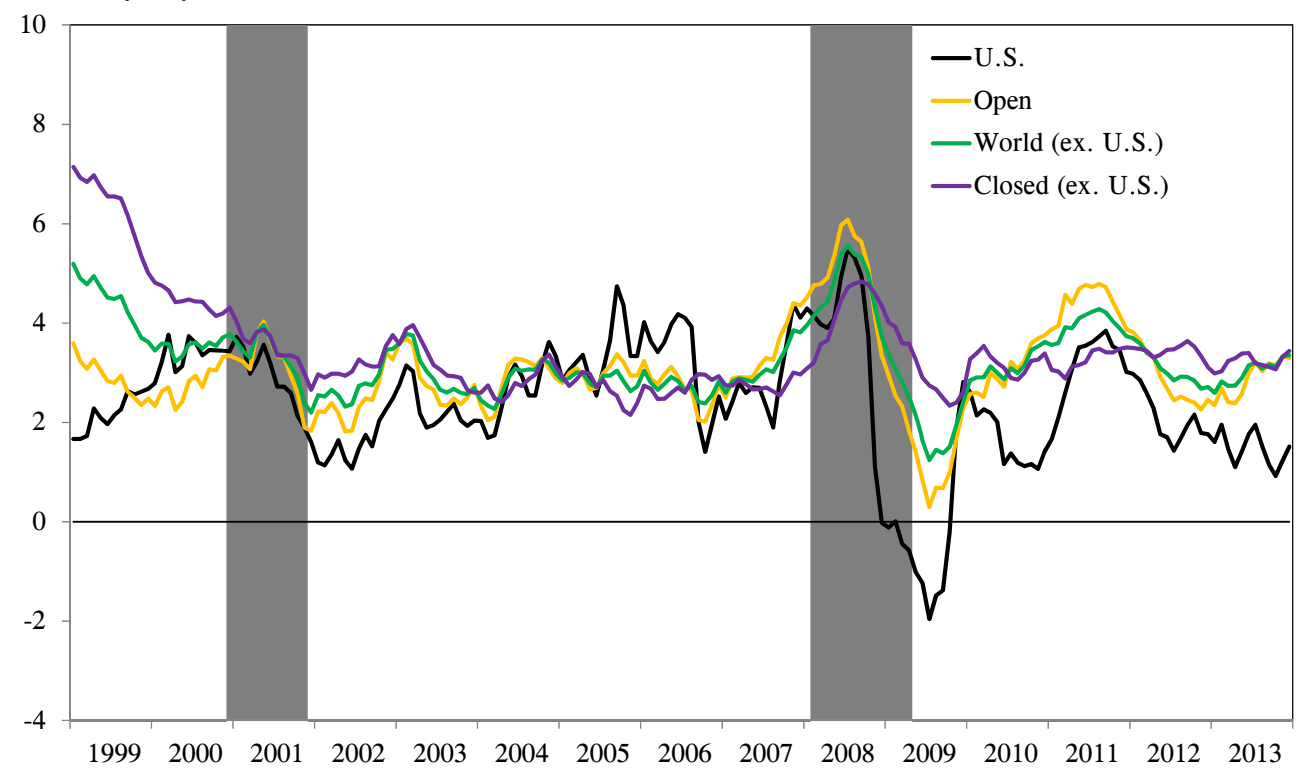

Note: Aggregated using U.S. trade weights. Shaded bars indicate global recessions (Grossman et al. 2014). 


\section{Figure 17. PPI/WPI Inflation}

\section{G40 PPI/WPI Inflation}

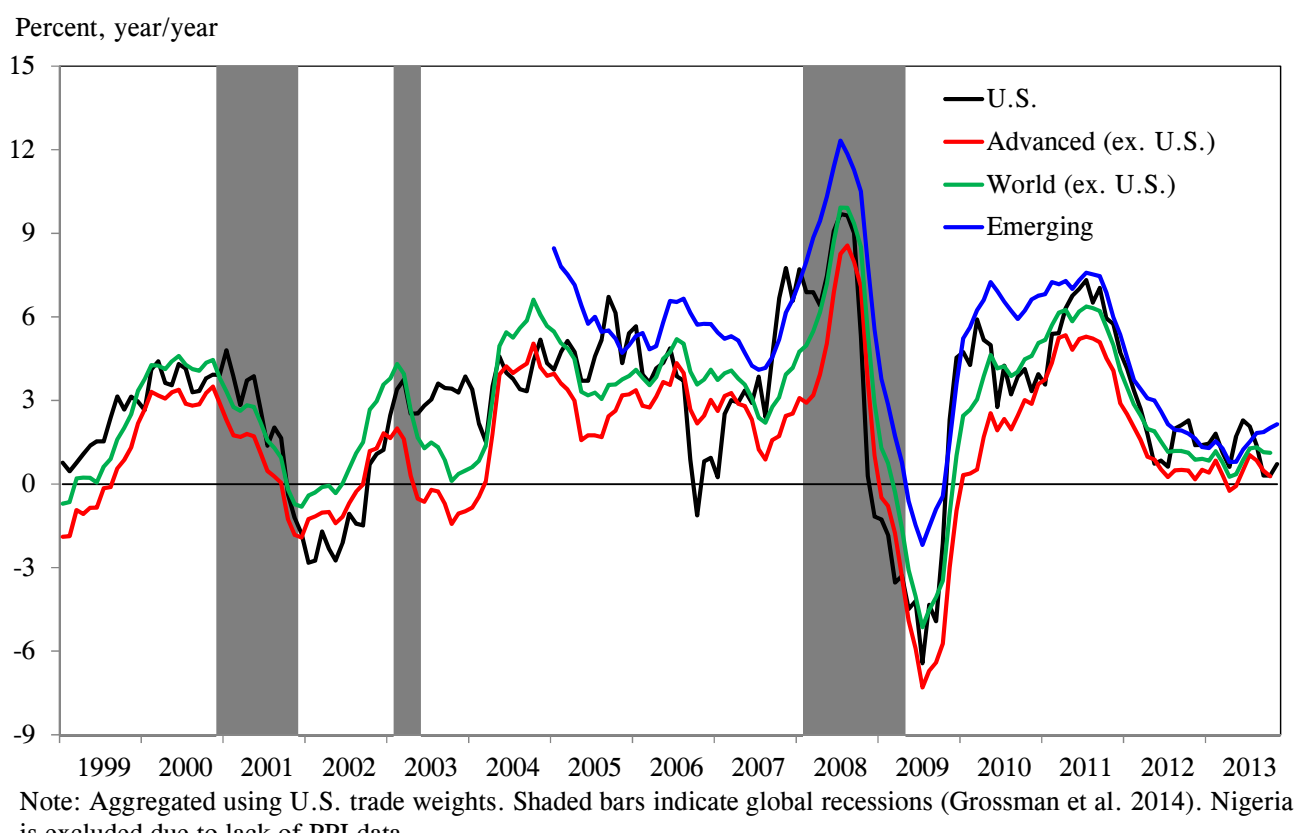

is excluded due to lack of PPI data.

\section{G40 PPI/WPI Inflation}

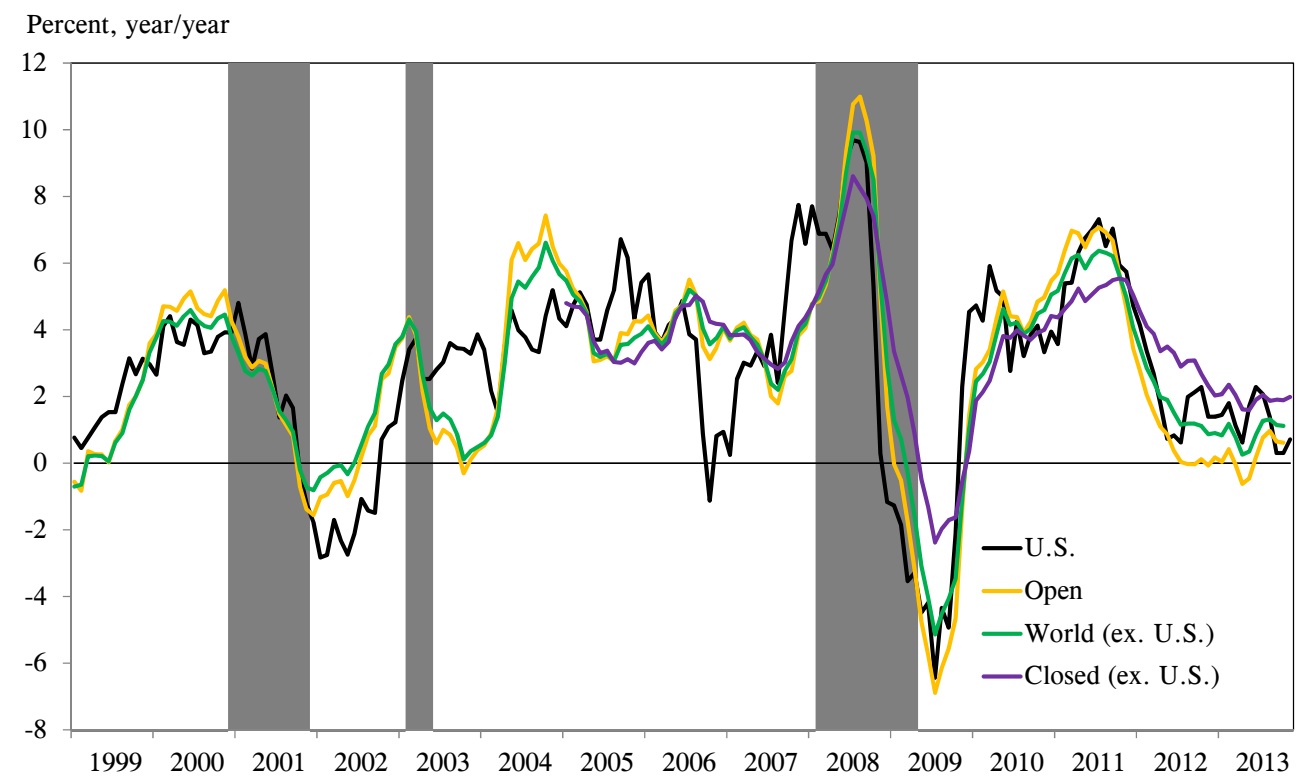

Note: Aggregated using U.S. trade weights. Shaded bars indicate global recessions (Grossman et al. 2014). Nigeria is excluded due to lack of PPI data. 
Figure 18. Core CPI Inflation (ex. Food and Energy)

G40 Core Inflation

Core CPI

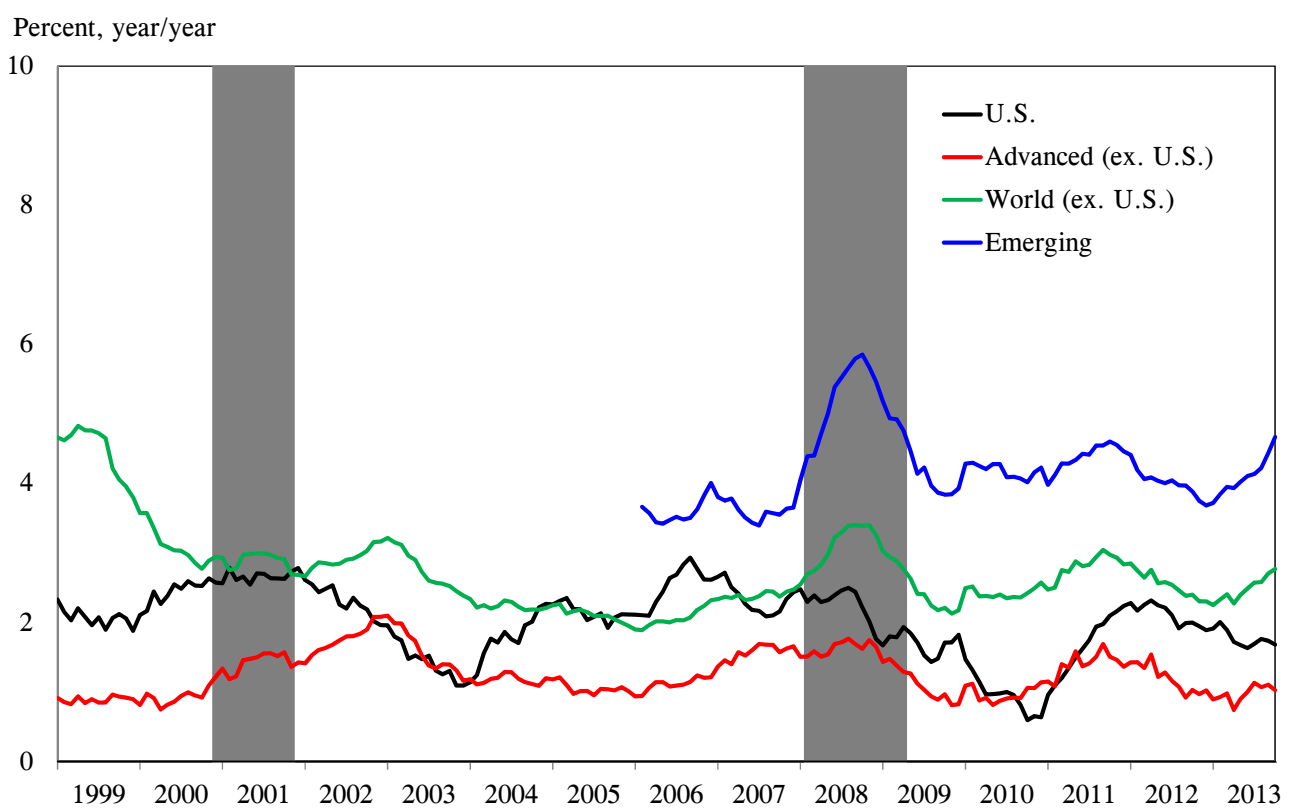

Note: Aggregated using U.S. trade weights. Shaded bars indicate global recessions (Grossman et al. 2014).

\section{G40 Core Inflation}

Core CPI

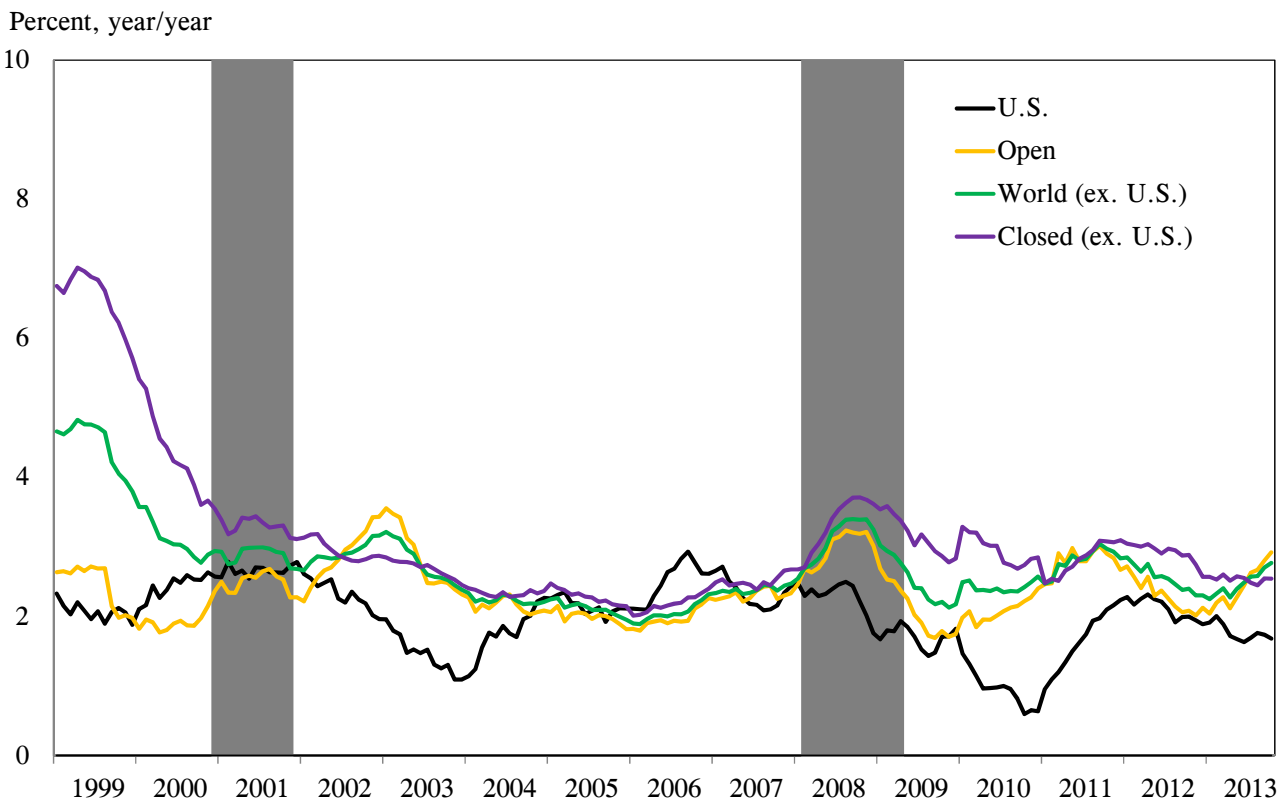

Note: Aggregated using U.S. trade weights. Shaded bars indicate global recessions (Grossman et al. 2014). 


\section{Figure 19. Nominal Exchange Rate}

\section{G40 Nominal Exchange Rates}

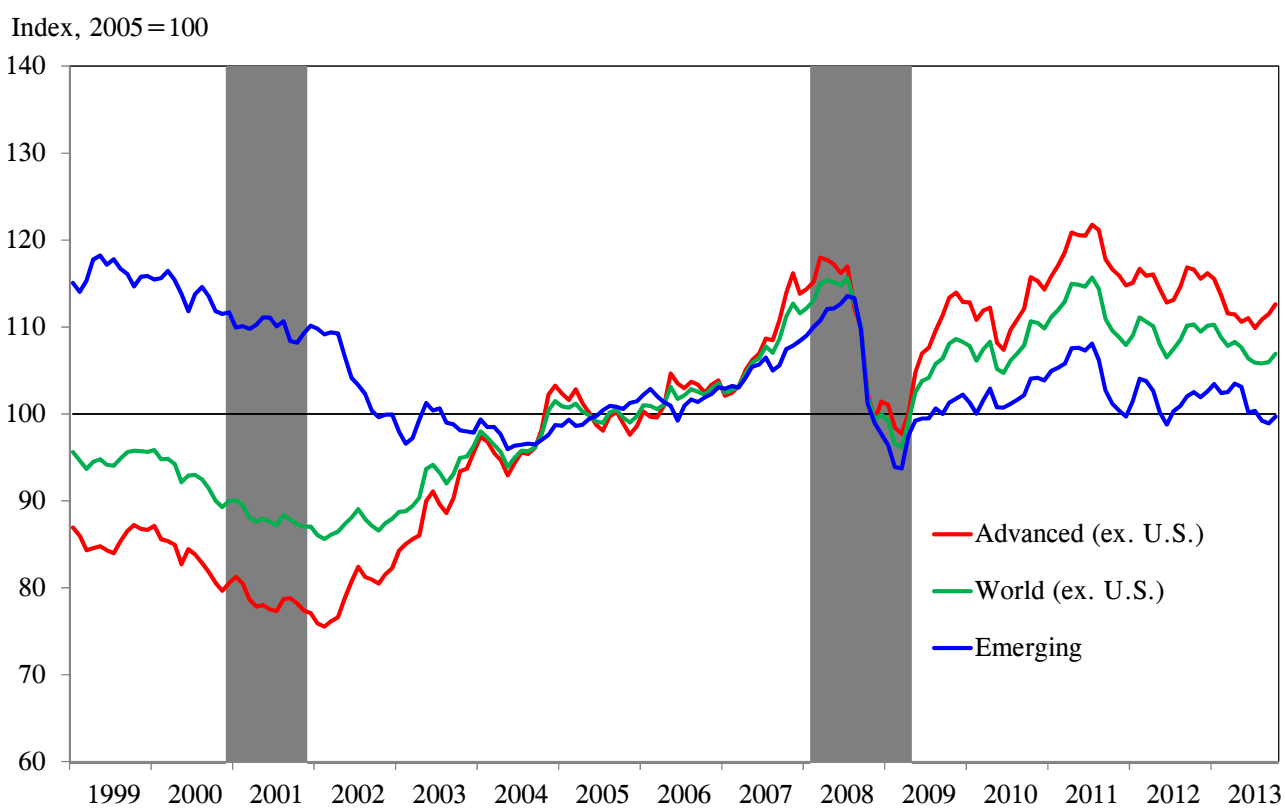

Note: Aggregated using U.S. trade weights. Shaded bars indicate global recessions (Grossman et al. 2014).

G40 Nominal Exchange Rates

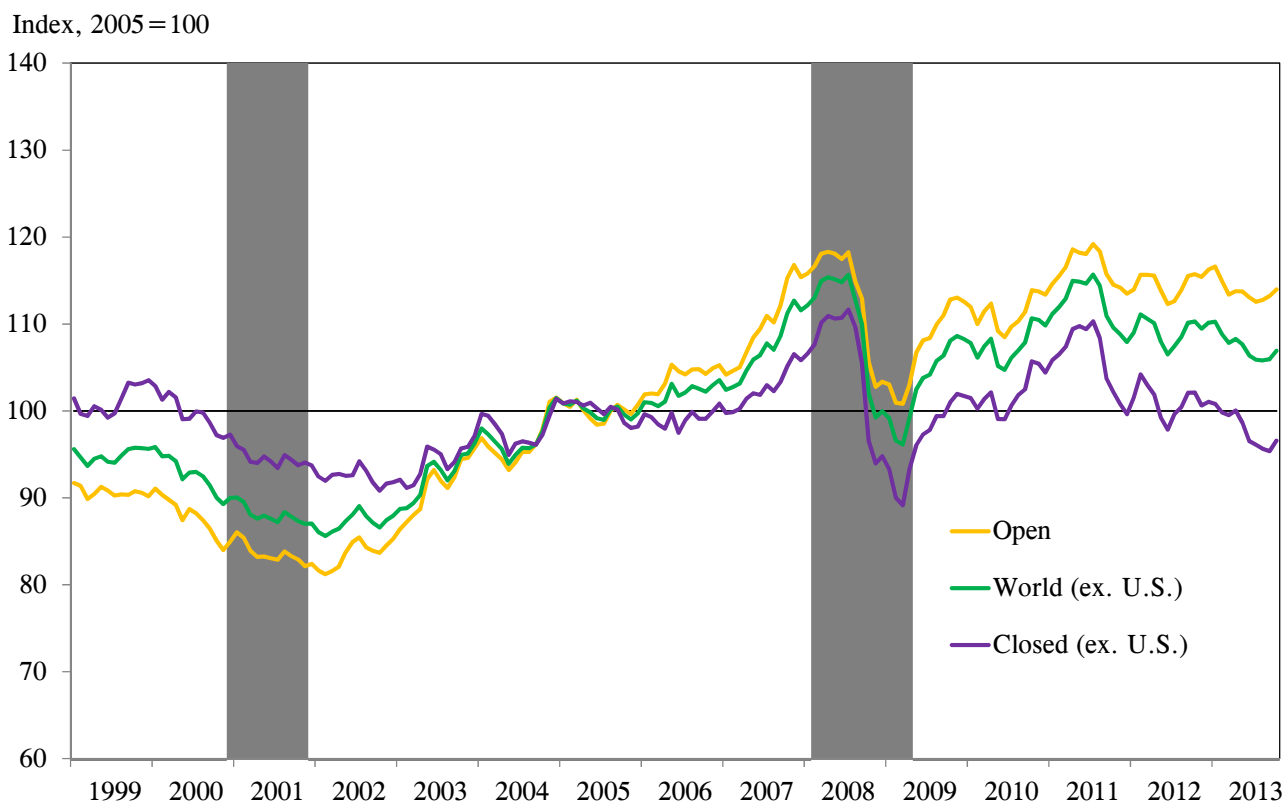

Note: Aggregated using U.S. trade weights. Shaded bars indicate global recessions (Grossman et al. 2014). 


\section{Figure 20. CPI-based Real Exchange Rate}

\section{G40 Real Exchange Rates}

CPI-based

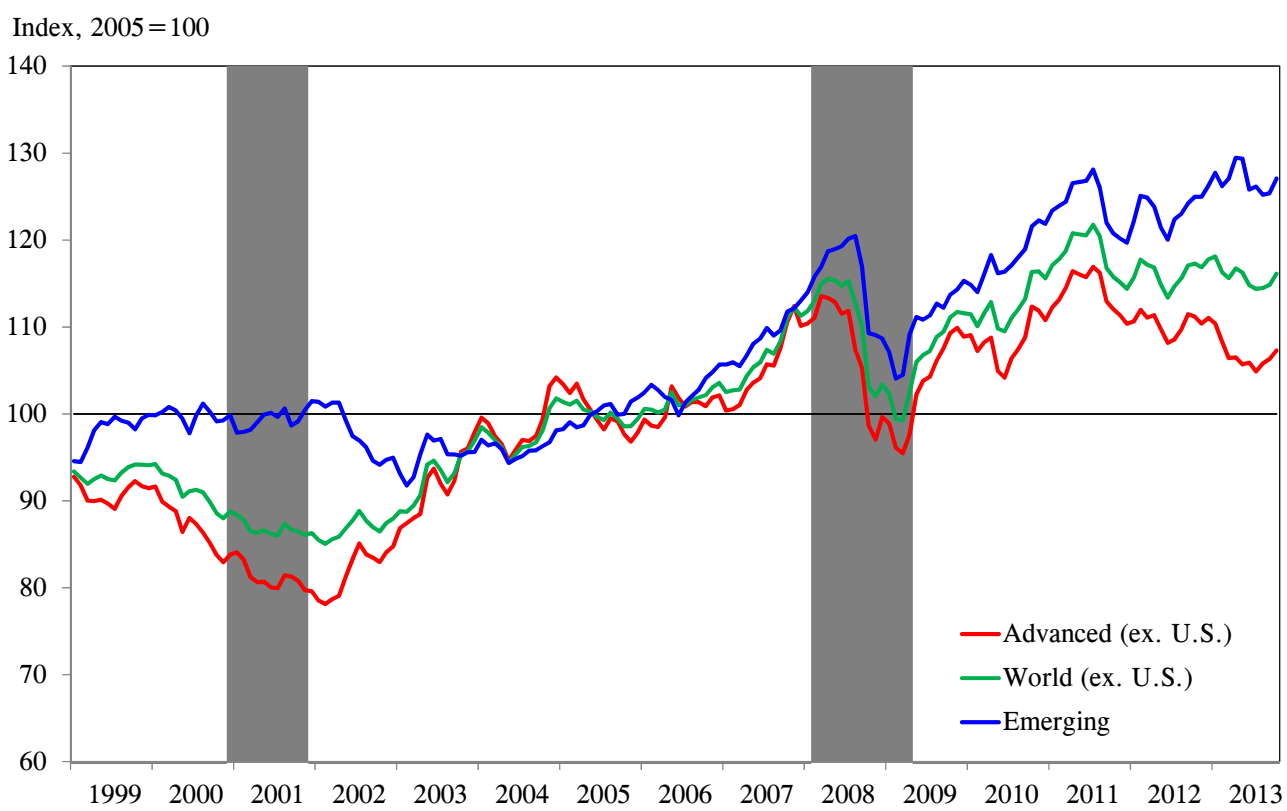

Note: Aggregated using U.S. trade weights. Shaded bars indicate global recessions (Grossman et al. 2014).

\section{G40 Real Exchange Rates}

CPI-based

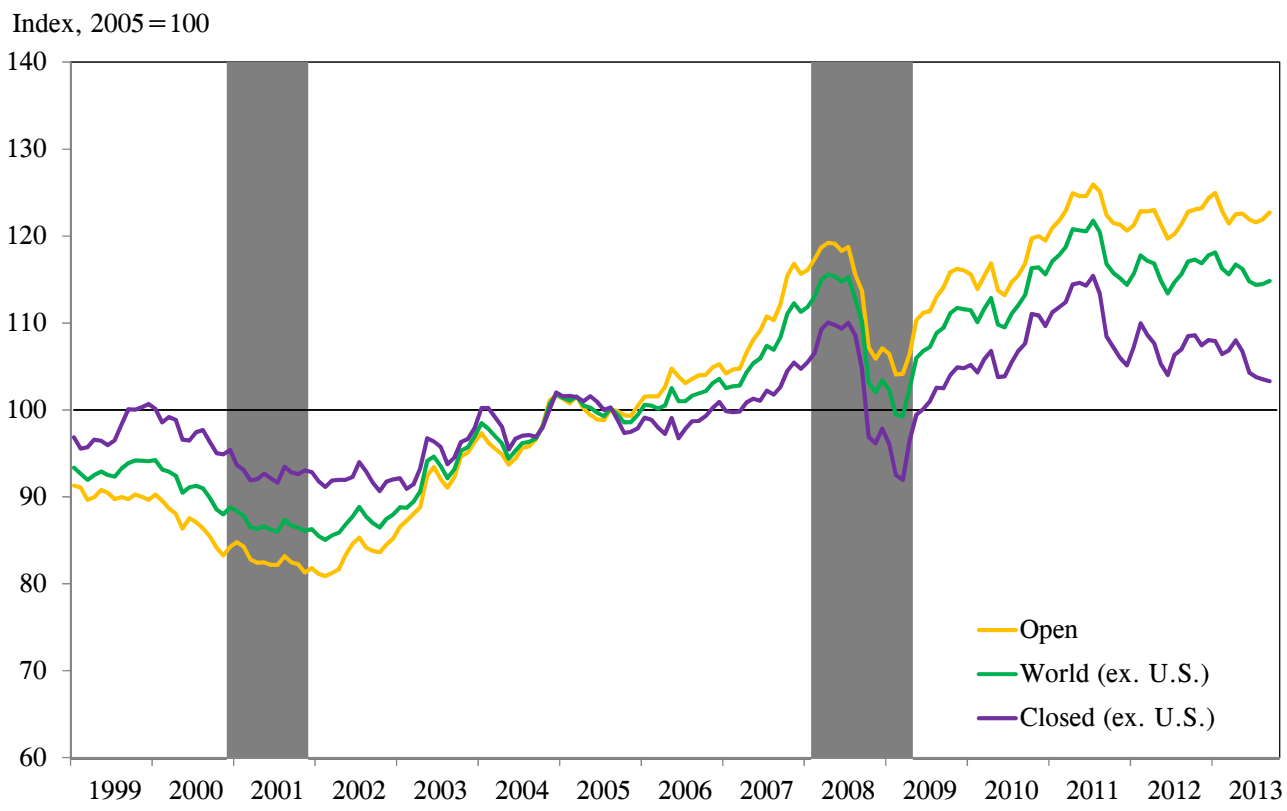

Note: Aggregated using U.S. trade weights. Shaded bars indicate global recessions (Grossman et al. 2014). 


\section{Figure 21. PPI/WPI-based Real Exchange Rate}

\section{G40 Real Exchange Rates}

PPI/WPI-based

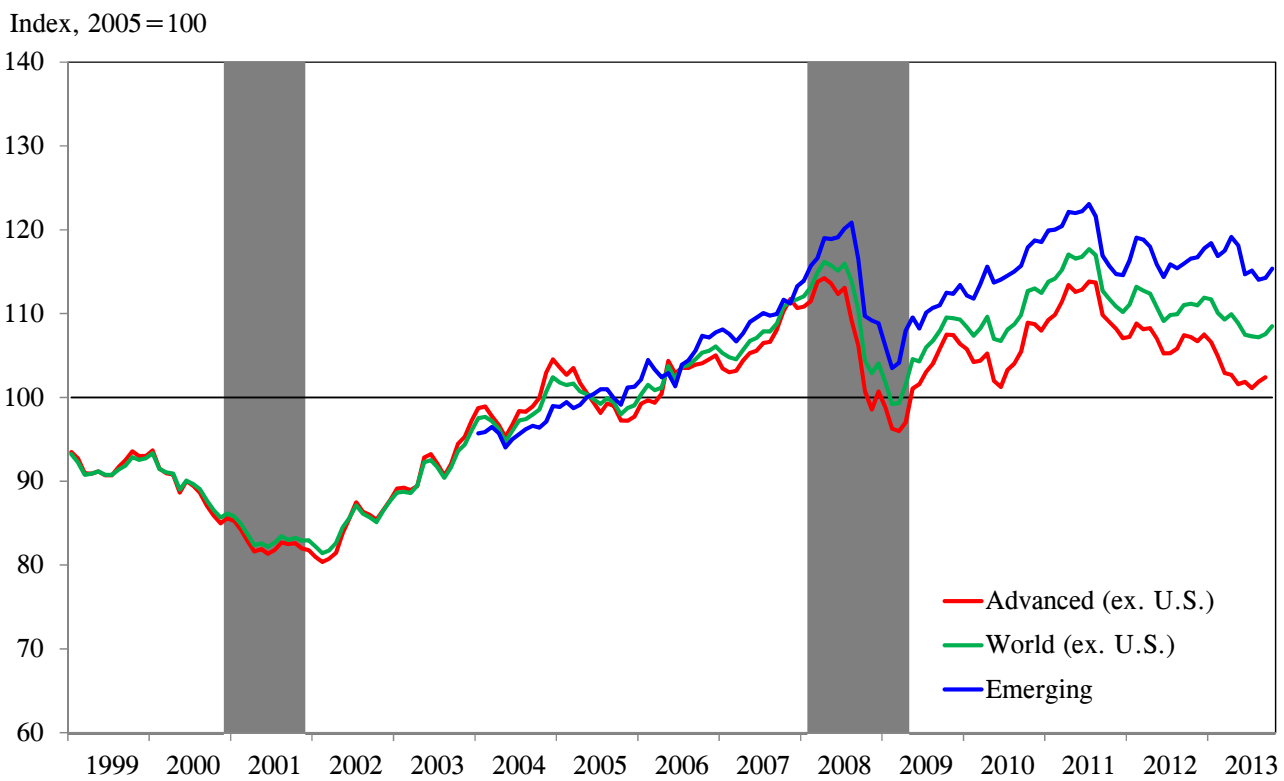

Note: Aggregated using U.S. trade weights. Shaded bars indicate global recessions (Grossman et al. 2014). Nigeria is excluded due to lack of PPI data.

\section{G40 Real Exchange Rates}

PPI/WPI-based

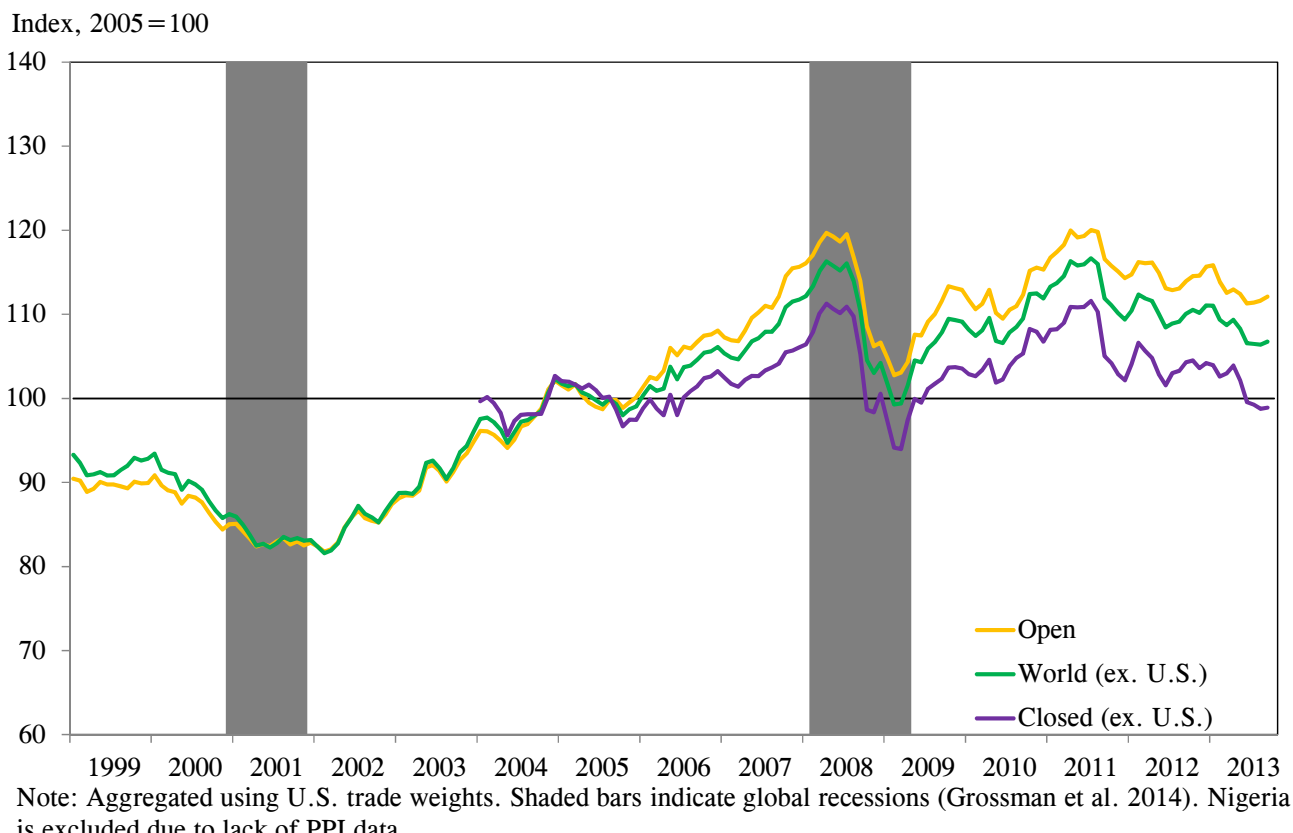

Note: Aggregated using U.S. trade weights. Shaded bars indicate global recessions (Grossman et al. 2014). Nigeria is excluded due to lack of PPI data. 


\subsection{Trade Indicators}

\section{Figure 22. Merchandise Exports}

\section{G40 Export Index}

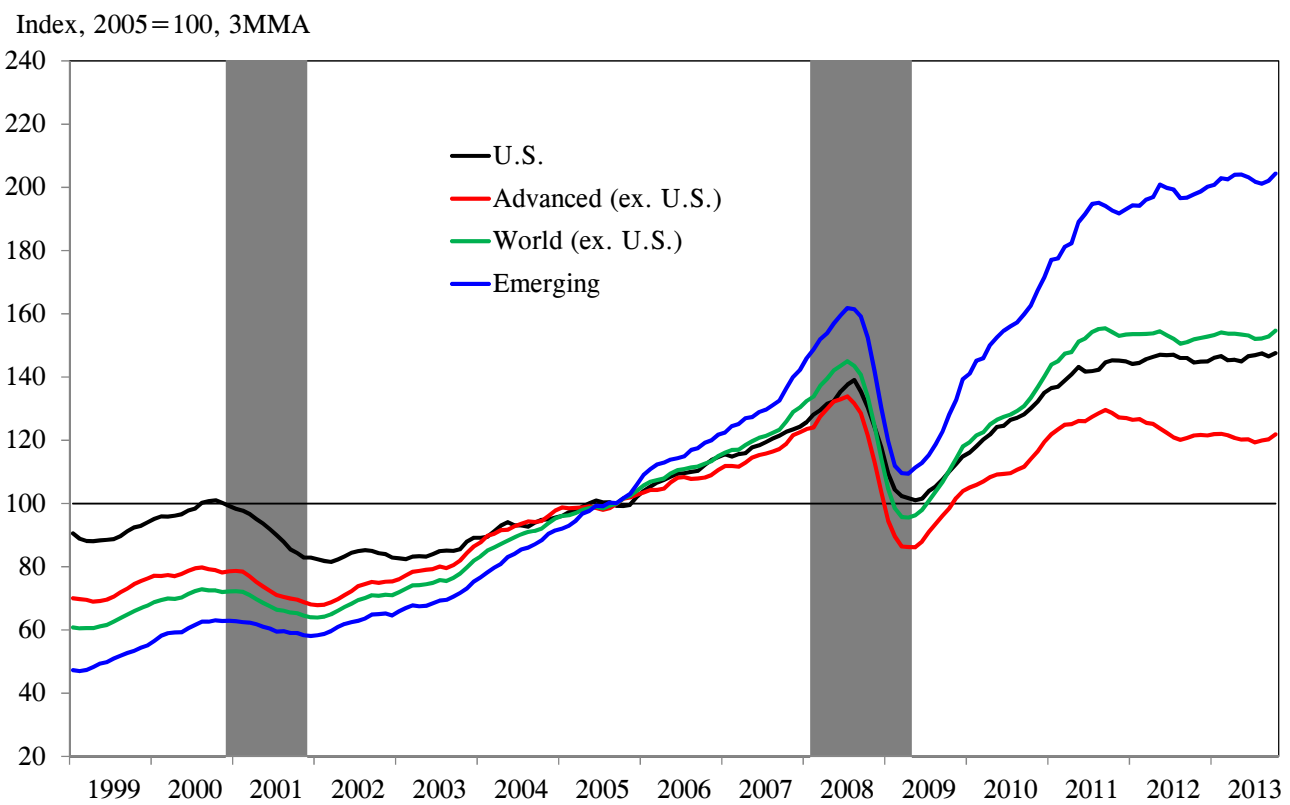

Note: Aggregated using U.S. trade weights. Shaded bars indicate global recessions (Grossman et al. 2014).

\section{G40 Export Index}

Index, 2005 =100, 3MMA

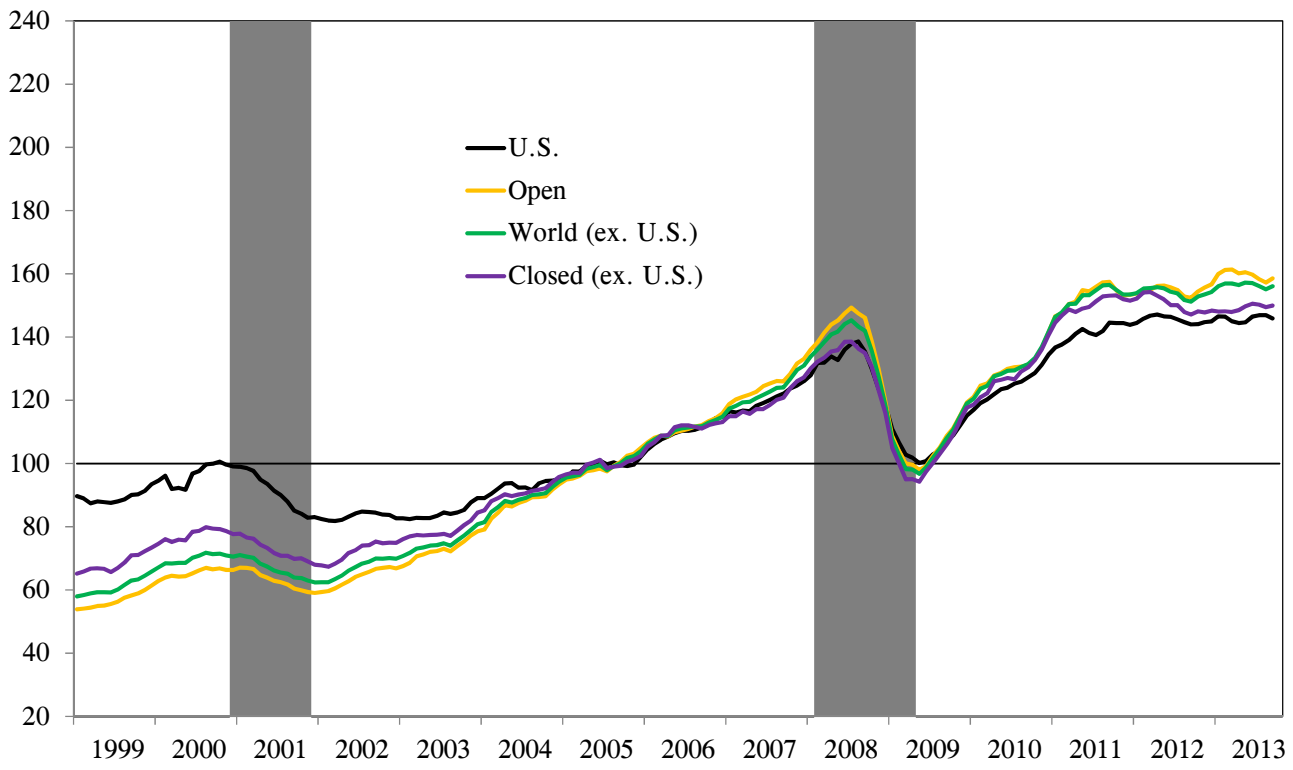

Note: Aggregated using U.S. trade weights. Shaded bars indicate global recessions (Grossman et al. 2014). 


\section{Figure 23. Merchandise Export Growth}

\section{G40 Export Growth}

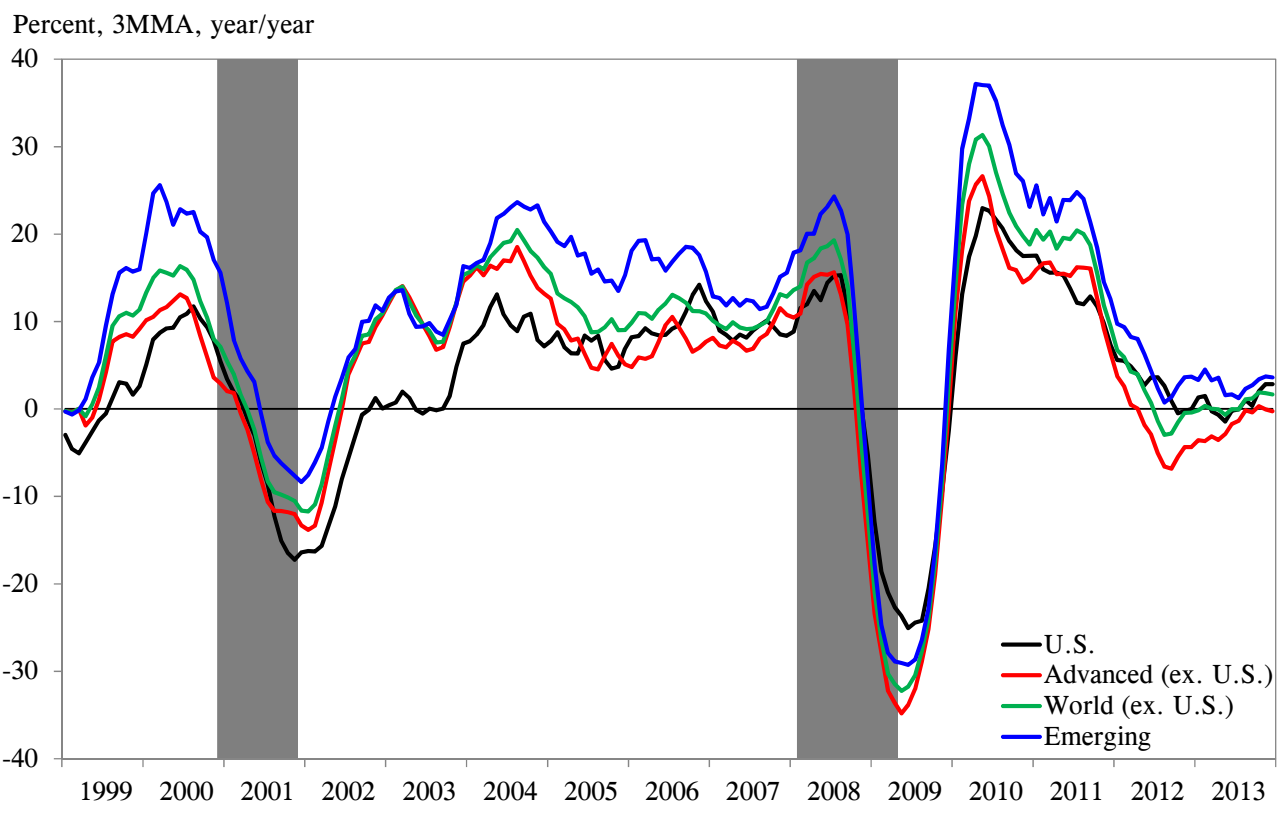

Note: Aggregated using U.S. trade weights. Shaded bars indicate global recessions (Grossman et al. 2014).

G40 Export Growth

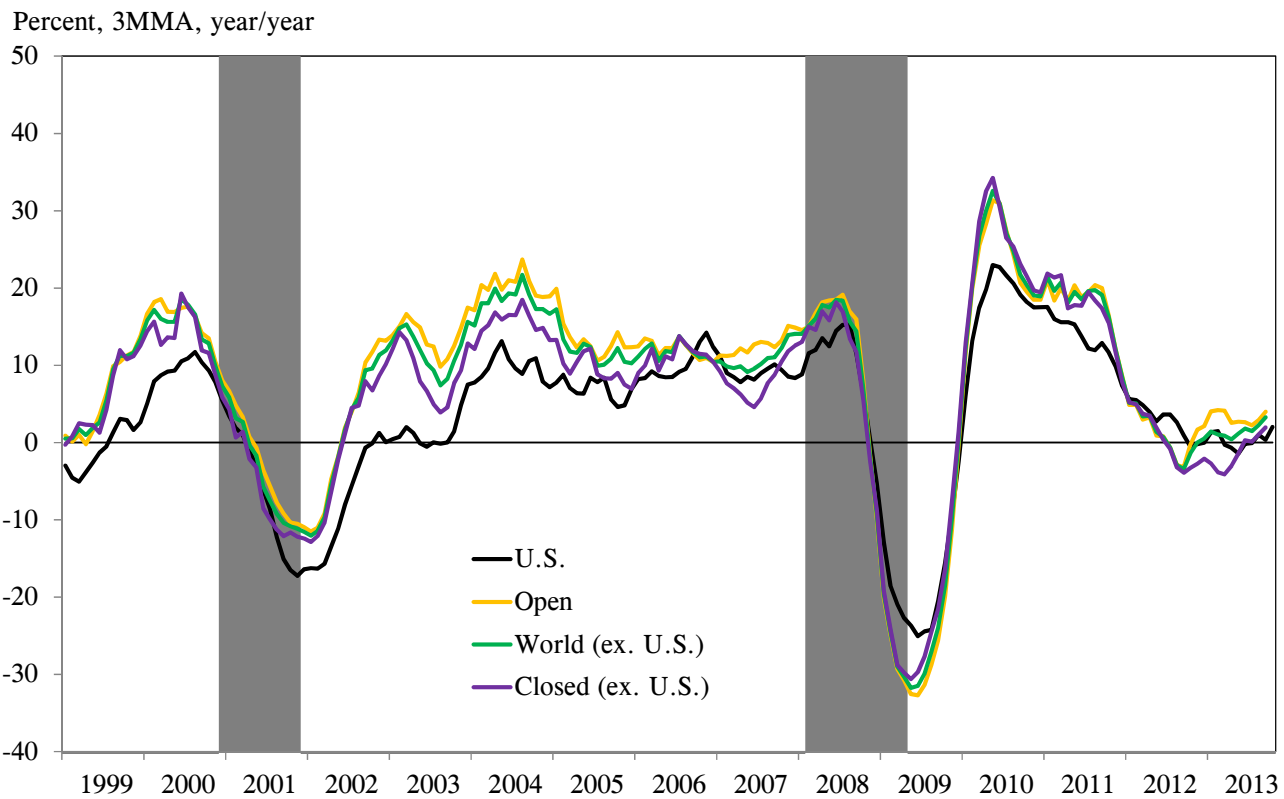

Note: Aggregated using U.S. trade weights. Shaded bars indicate global recessions (Grossman et al. 2014). 


\section{Figure 24. Merchandise Imports}

\section{G40 Import Growth}

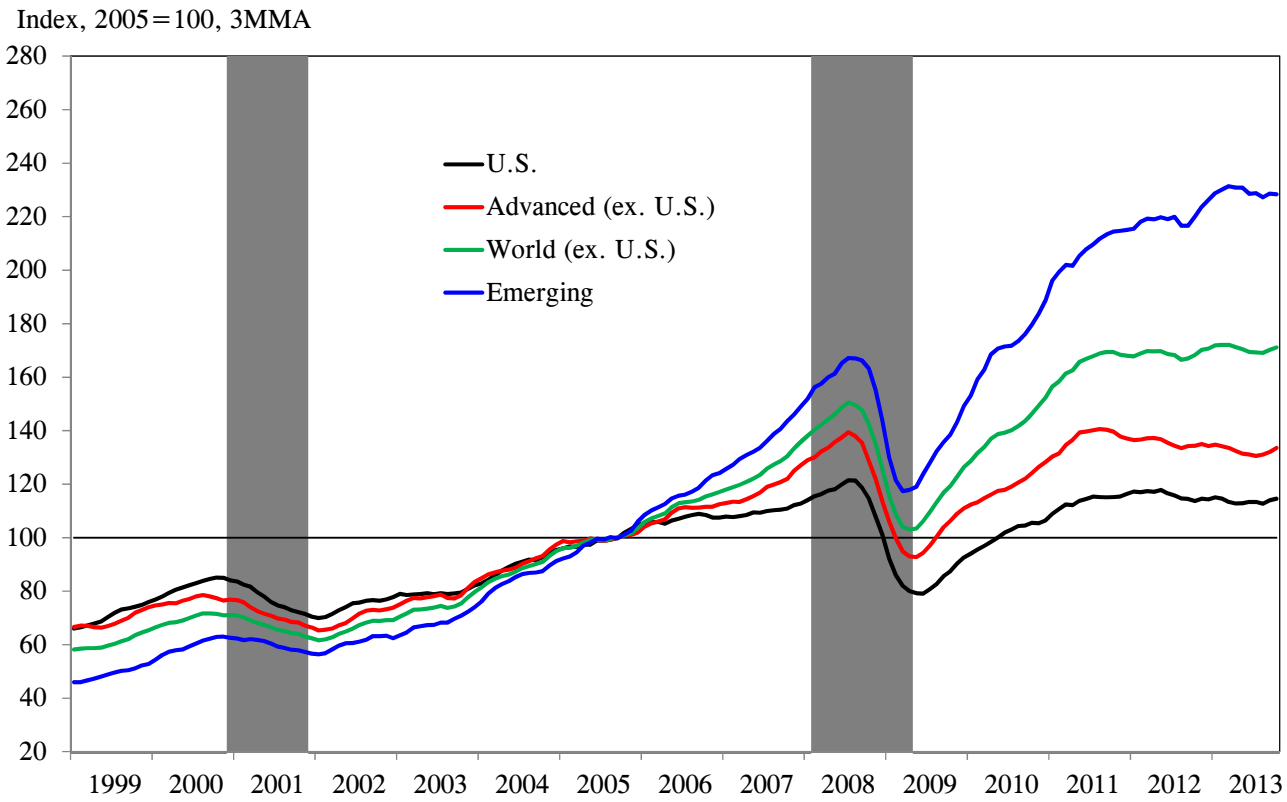

Note: Aggregated using U.S. trade weights. Shaded bars indicate global recessions (Grossman et al. 2014).

G40 Import Growth

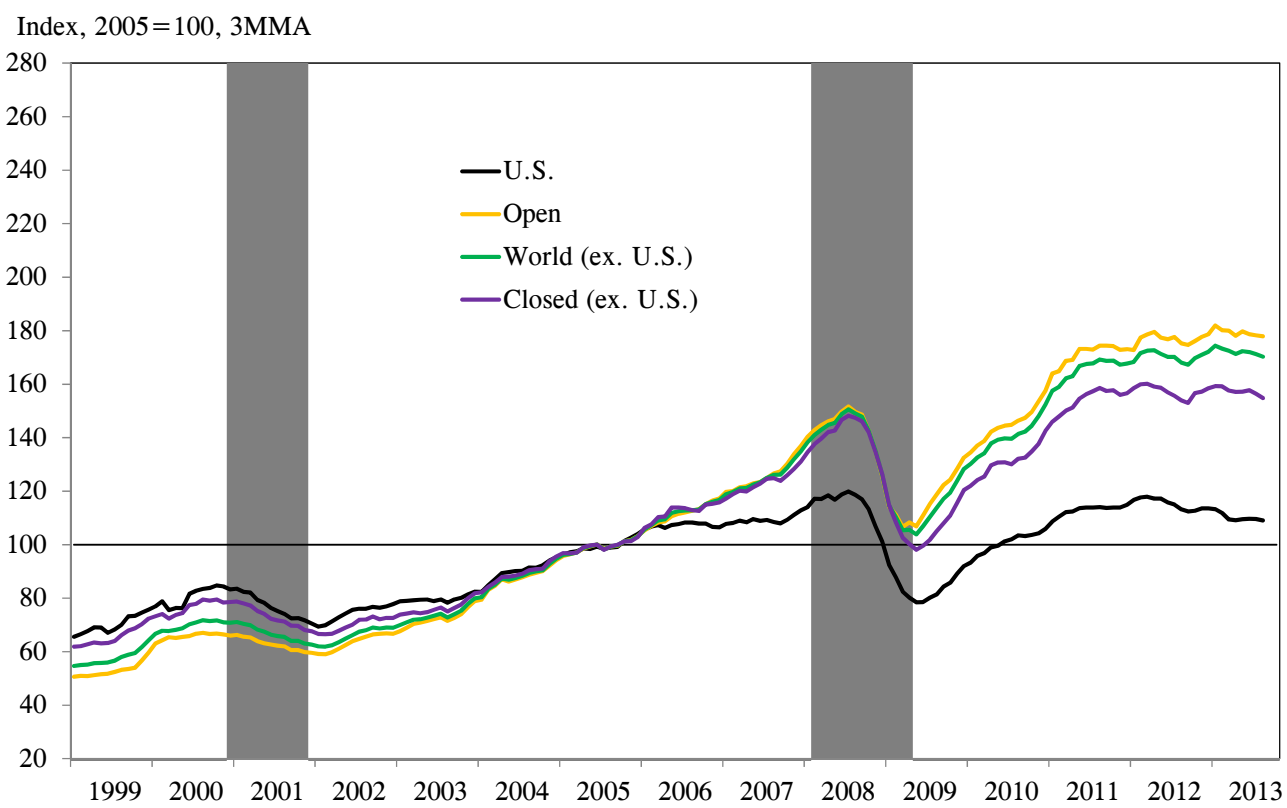

Note: Aggregated using U.S. trade weights. Shaded bars indicate global recessions (Grossman et al. 2014). 


\section{Figure 25. Merchandise Import Growth}

\section{G40 Import Growth}

Percent, 3MMA, year/year

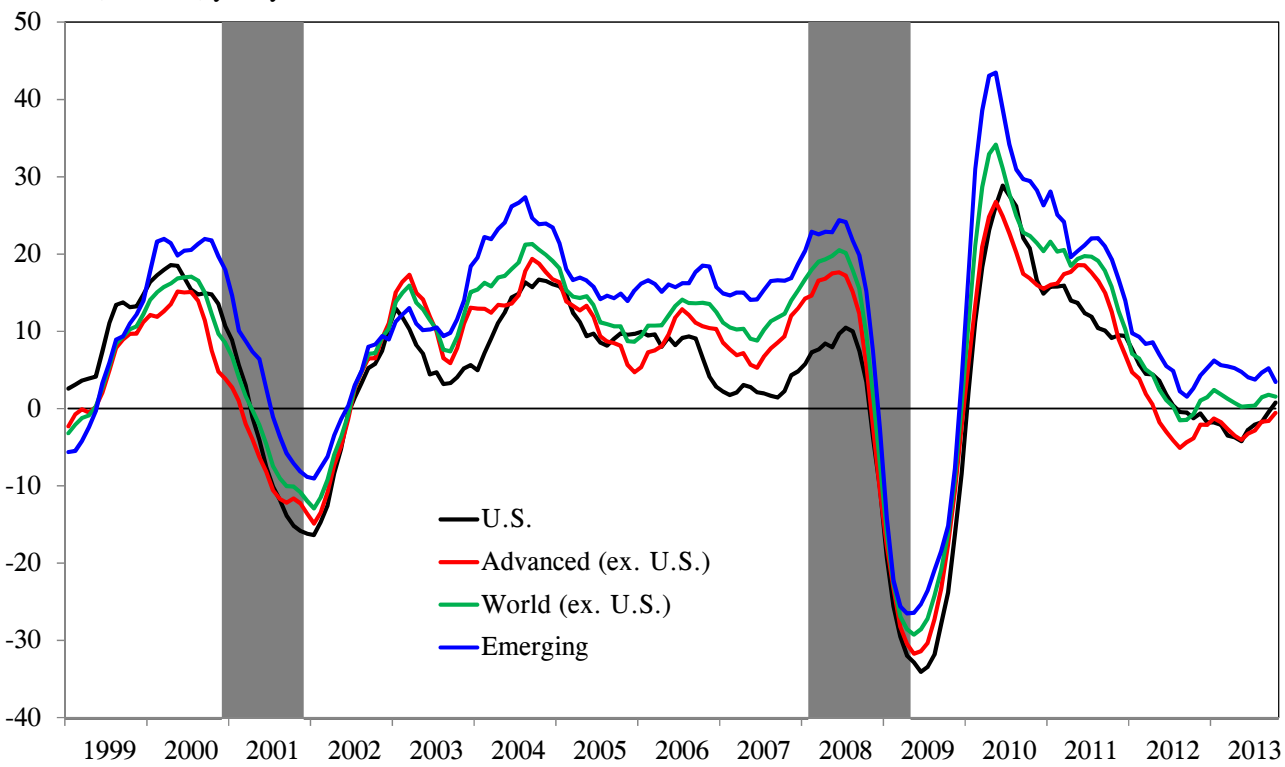

Note: Aggregated using U.S. trade weights. Shaded bars indicate global recessions (Grossman et al. 2014).

G40 Import Growth

Percent, 3MMA, year/year

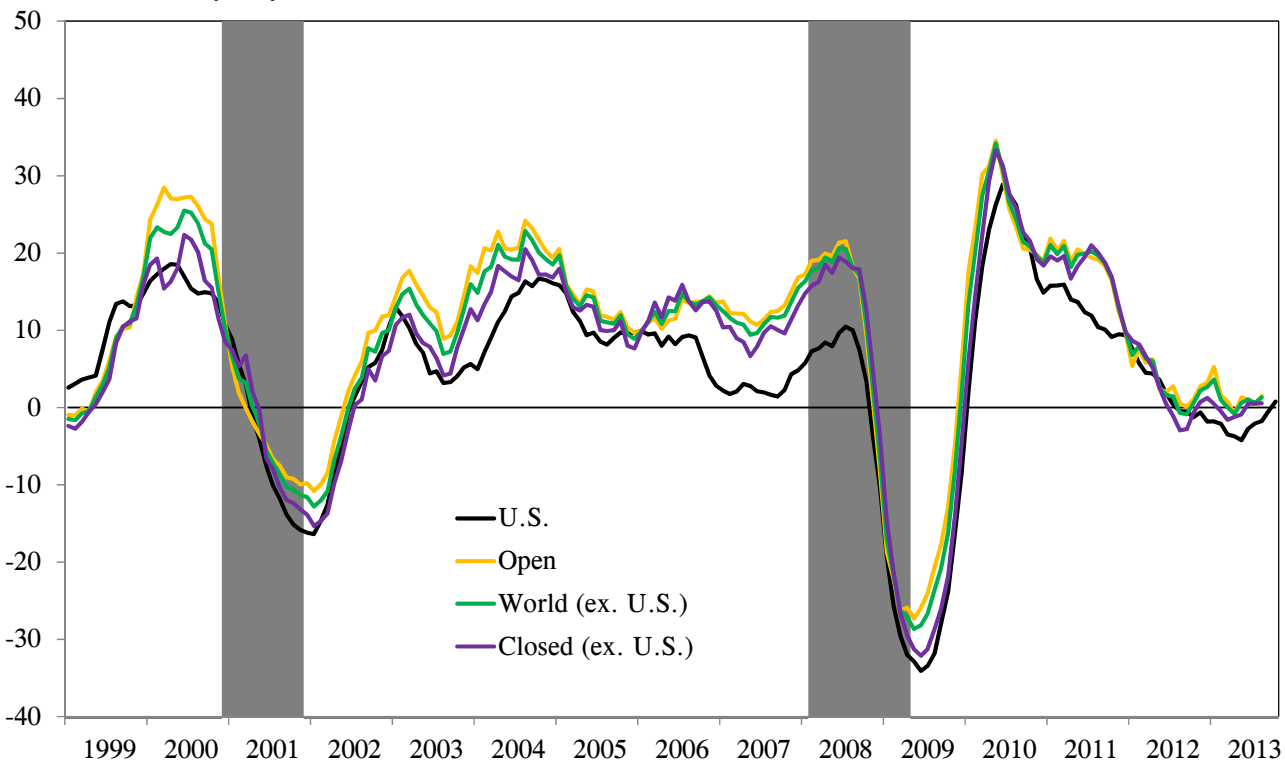

Note: Aggregated using U.S. trade weights. Shaded bars indicate global recessions (Grossman et al. 2014). 


\subsection{Financial Indicators}

Figure 26. Official/Policy Rates

G40 Official/Policy Interest Rate

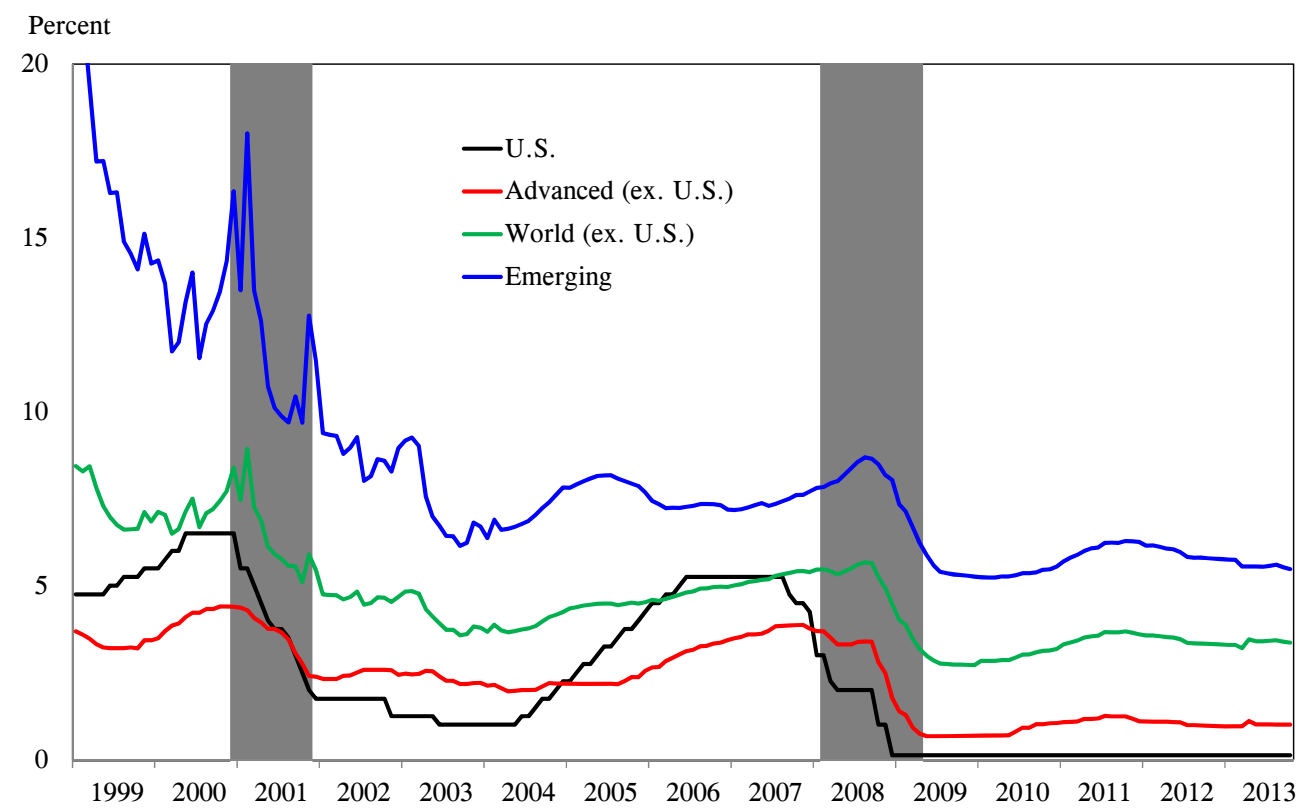

Note: Aggregated using U.S. trade weights. Shaded bars indicate global recessions (Grossman et al. 2014).

G40 Official/Policy Interest Rate

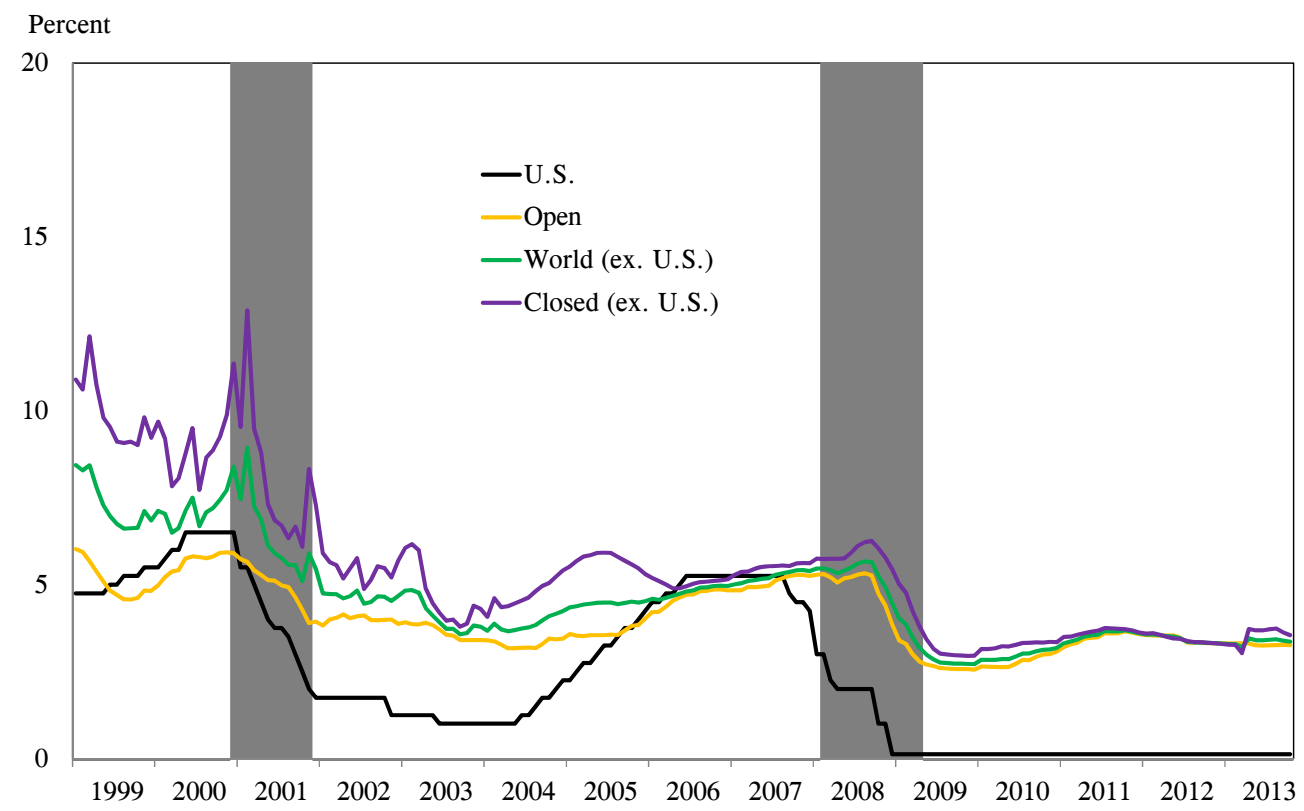

Note: Aggregated using U.S. trade weights. Shaded bars indicate global recessions (Grossman et al. 2014). 


\section{Figure 27. Long-Term Bond Yields}

\section{G40 Long-Term Bond Yields}

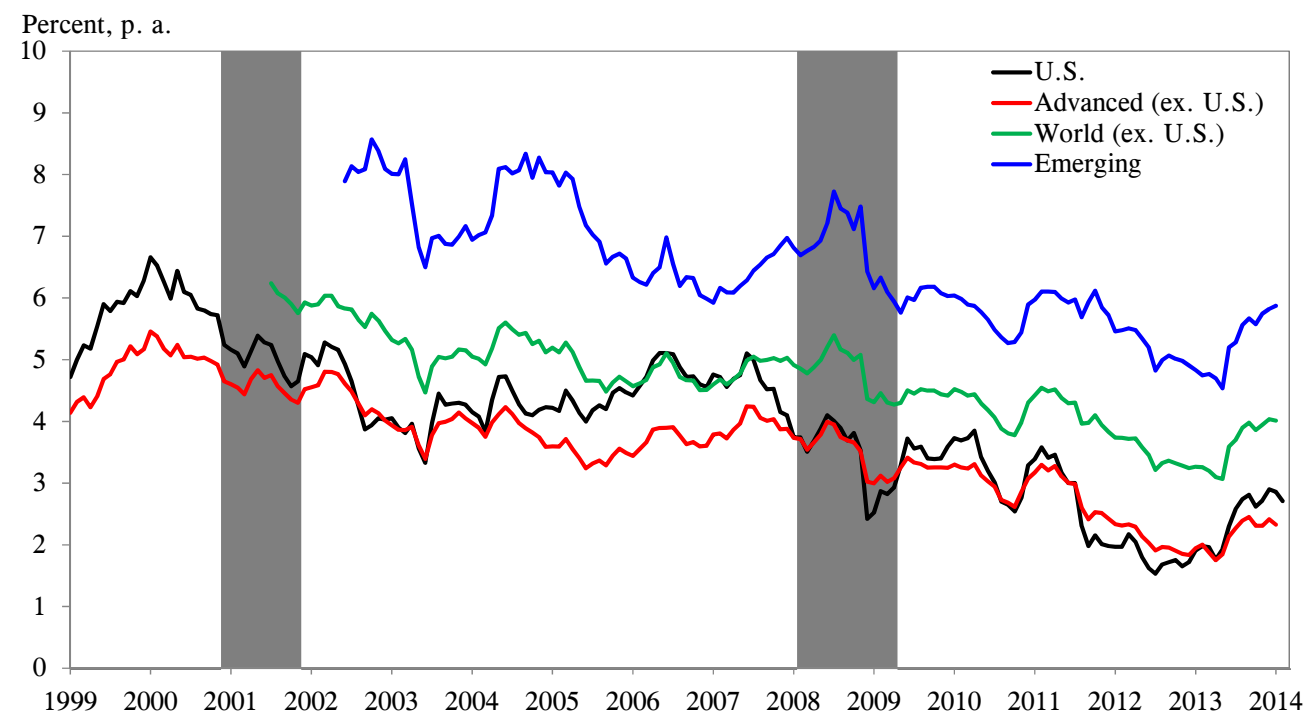

Note: Aggregated using U.S. trade weights. Shaded bars indicate global recessions (Grossman et al. 2014).

Countries with data starting after Jan. 2006 are Brazil (Nov. 2006), Venezuela (June 2006), Nigeria (Jul. 2007),

Peru (Mar. 2006) and Turkey (Oct. 2006). Argentina, Costa Rica and Indonesia are excluded due to lack of data.

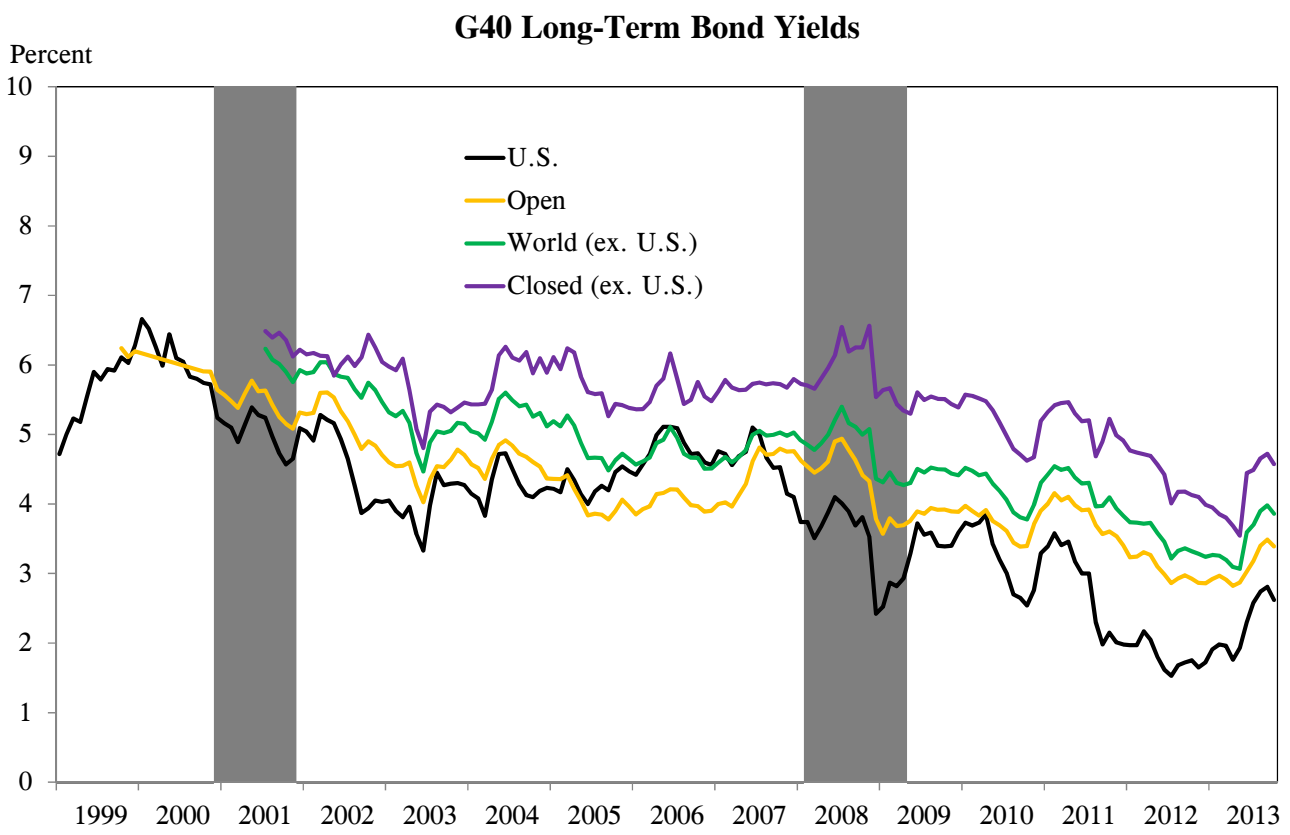

Note: Aggregated using U.S. trade weights. Shaded bars indicate global recessions (Grossman et al. 2014).

Countries with data starting after Jan. 2006 are Brazil (Nov. 2006), Venezuela (June 2006), Nigeria (Jul. 2007),

Peru (Mar. 2006) and Turkey (Oct. 2006). Argentina, Costa Rica and Indonesia are excluded due to lack of data. 


\section{The Database of Global Economic Indicators (DGEI): Country Detail}

For a selected group of countries in DGEI, we provide country-level detail as well.

Country Coverage:

Includes most of the top-20 economies by share of world GDP in 2005 as can be seen from Table 6: Euro area, United Kingdom, Japan, Canada, Australia, the BRICS countries (Brazil, Russia, India, China, South Africa), and the MIST countries (Mexico, Indonesia, South Korea, and Turkey).

Variables per country (Figure 28 through Figure 32):

Real: Q/Q annualized and $4 \mathrm{Q} \%$ change for real GDP, unemployment rate.

Nominal: year-over-year headline CPI, year-over-year core CPI (excluding food and energy), target range for monetary policy.

Table 6. U.S. and Top-20 Foreign Economies by Size in 2005

\begin{tabular}{|c|c|c|c|}
\hline Country & $\%$ of World PPP-adj. GDP (2005) & \% World Trade (2005) & Classification \\
\hline U.S. & $(22.16)$ & $(12.47)$ & Advanced \\
\hline Euro Area & 16.18 & 29.11 & Advanced \\
\hline China & 9.42 & 6.73 & Emerging \\
\hline Japan & 6.83 & 5.25 & Advanced \\
\hline India & 4.26 & 1.13 & Emerging \\
\hline U.K. & 3.42 & 4.33 & Advanced \\
\hline Russia & 2.98 & 1.59 & Emerging \\
\hline Brazil & 2.78 & 0.94 & Emerging \\
\hline Mexico & 2.28 & 2.17 & Emerging \\
\hline Canada & 2.04 & 3.34 & Advanced \\
\hline S. Korea & 1.93 & 2.58 & Advanced \\
\hline Turkey & 1.31 & 0.90 & Emerging \\
\hline Indonesia & 1.24 & 0.68 & Emerging \\
\hline Australia & 1.21 & 1.12 & Advanced \\
\hline Iran & (1.20) & $(--)$ & Emerging \\
\hline Taiwan & (1.07) & $(--)$ & Advanced \\
\hline Poland & $(0.91)$ & $(0.90)$ & Emerging \\
\hline Saudi Arabia & $(0.90)$ & (1.01) & Emerging \\
\hline Thailand & $(0.78)$ & (1.08) & Emerging \\
\hline Argentina & $(0.74)$ & (0.33) & Emerging \\
\hline South Africa & 0.71 & 0.53 & Emerging \\
\hline $\begin{array}{l}\text { TOTAL (incl. U.S.) } \\
\text { of which }\end{array}$ & 78.75 & 72.85 & \\
\hline Advanced Share & $68.28(58.81)$ & $79.88(70.10)$ & \\
\hline Emerging Share & 31.72 (41.19) & $20.12(29.90)$ & \\
\hline
\end{tabular}

Note: Italics indicate the top-20 foreign economies and the U.S. for which country detail is not provided in DGEI. The totals are computed including only the countries in the current country detail plus the U.S. Trade data comes from the IMF Direction of Trade (DOT) database, while PPP-adjusted GDP shares are from the IMF World Economic Outlook (WEO). 
Figure 28. Country Detail: Euro Area, United Kingdom, and Japan

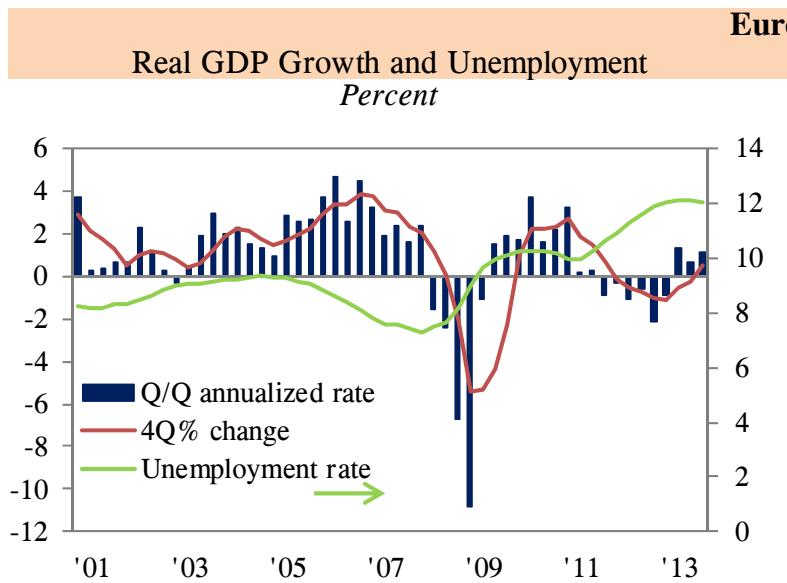

Euro Area

th and Unemployment

14 ,

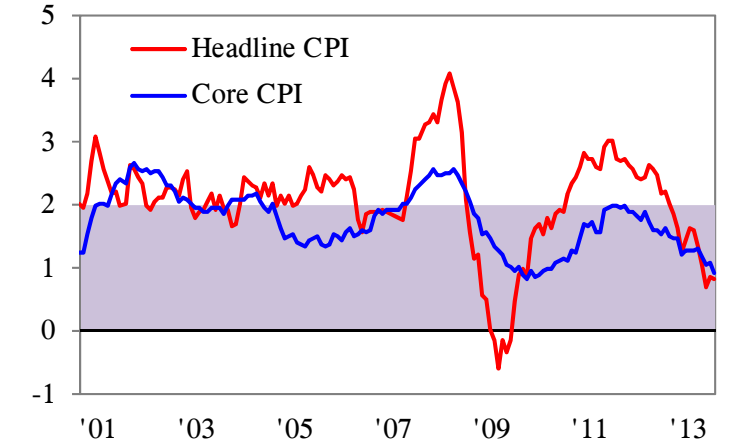

Note: The ECB's inflation target is "close to but below" $2 \%$ over the medium term.
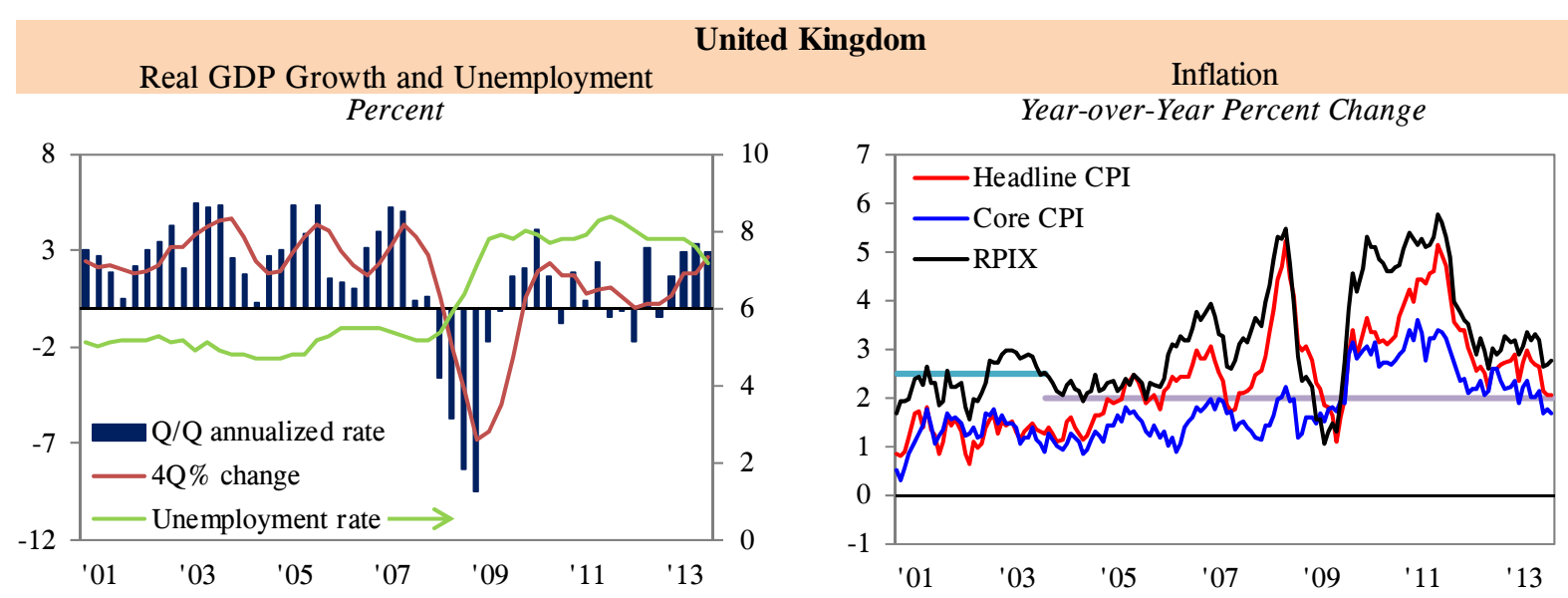

Note: The current inflation target is $2 \%$ for the

Harmonized CPI. Prior to December 2003, the inflation target was $2.5 \%$ for the RPIX.

\section{Japan}

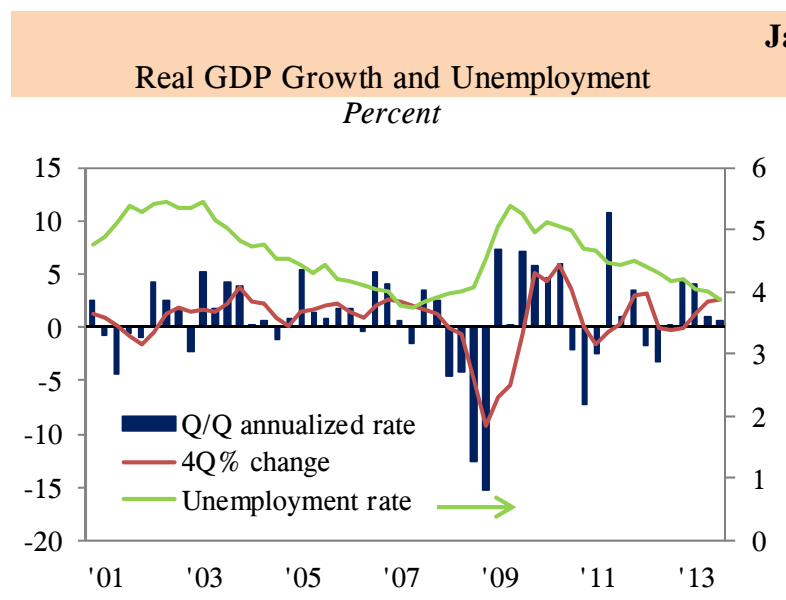

\section{Percent}

Inflation

Year-over-Year Percent Change

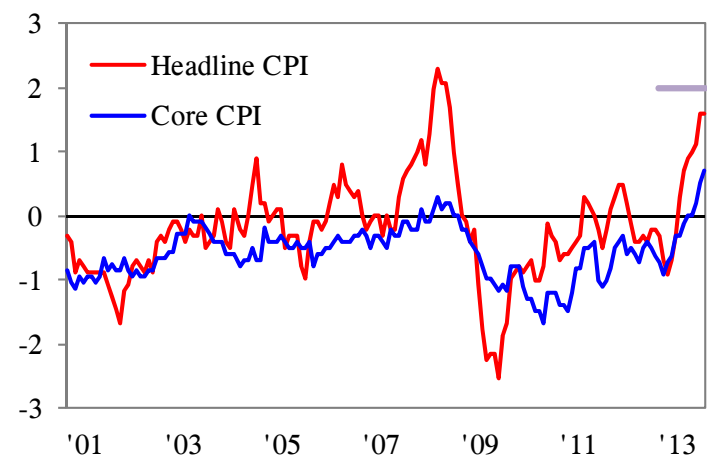

Note: An inflation target of $2 \%$ was implemented January 2013. 
Figure 29. Country Detail: Canada, Australia, and Brazil

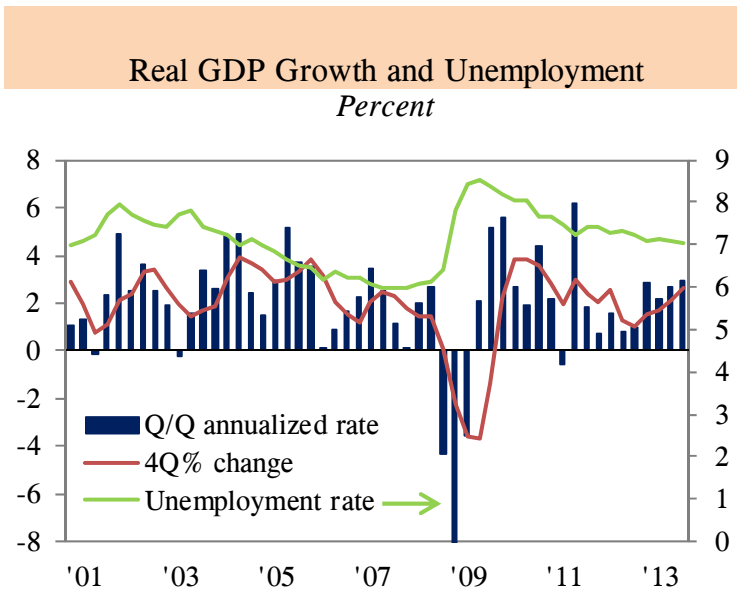

\section{Canada}

Percent

Inflation

Year-over-Year Percent Change

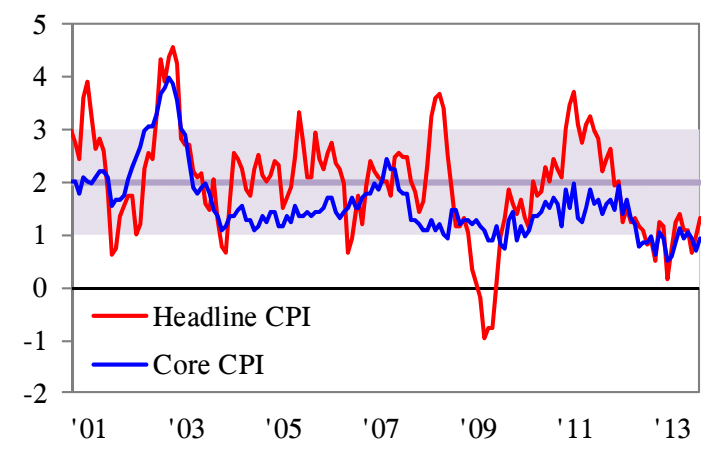

Note: The Bank of Canada's inflation target is $2( \pm 1) \%$.

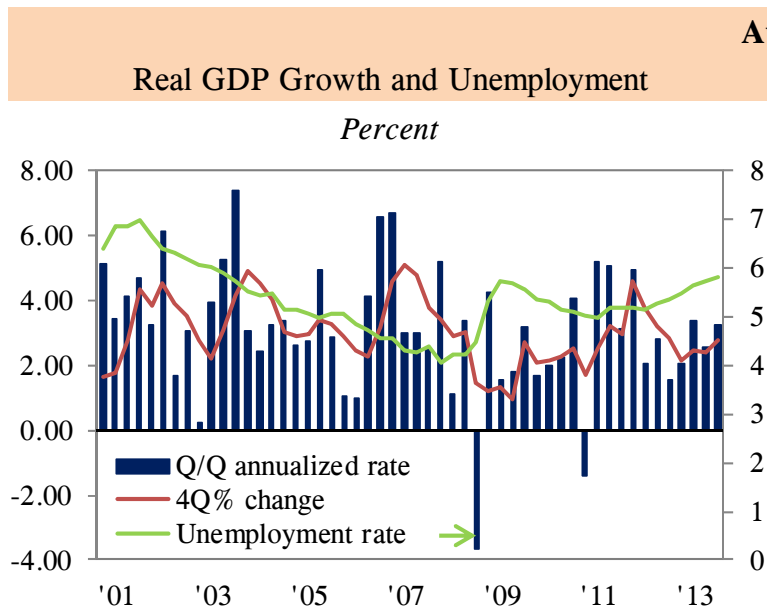

\section{Australia}

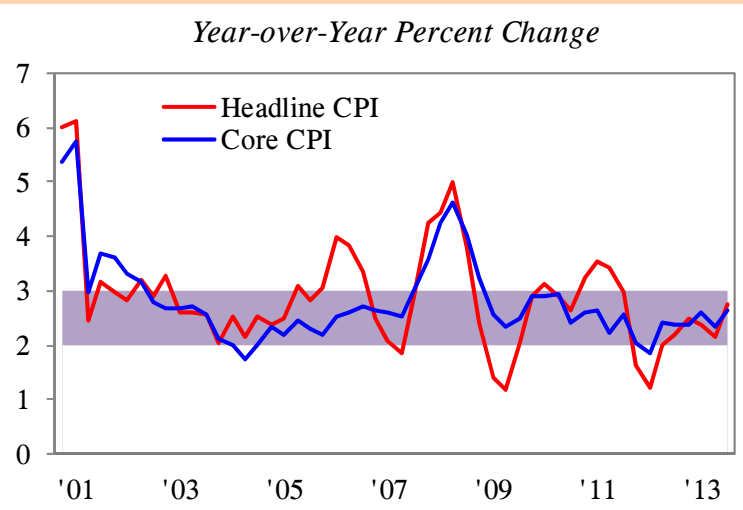

Note: The Reserve Bank of Australia's inflation target is 2$3 \%$.

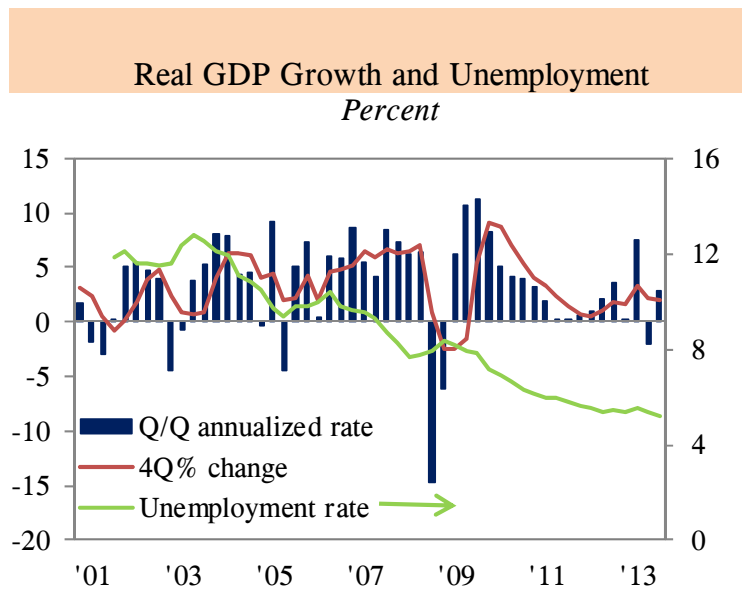

\section{Brazil}

Inflation

Year-over-Year Percent Change

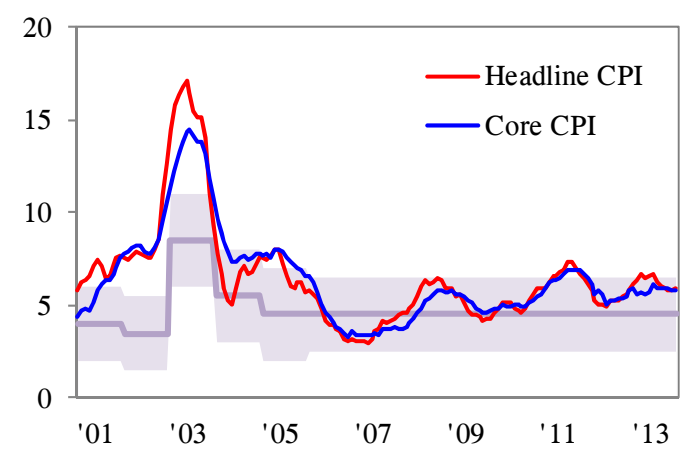

Note: The current inflation target is $4.5( \pm 2) \%$. 
Figure 30. Country Detail: Russia, India, and China
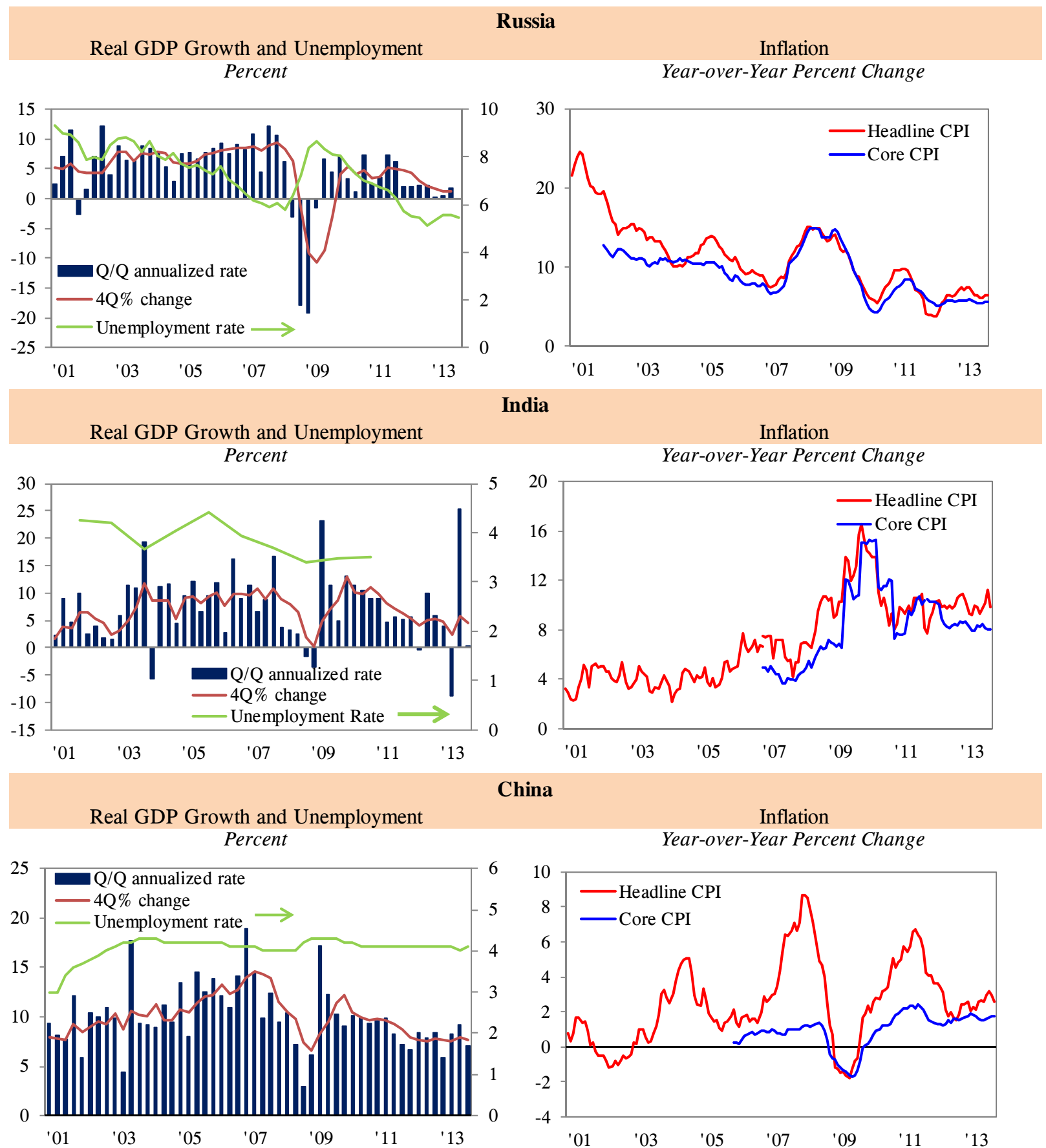

\section{China}

Inflation

Year-over-Year Percent Change

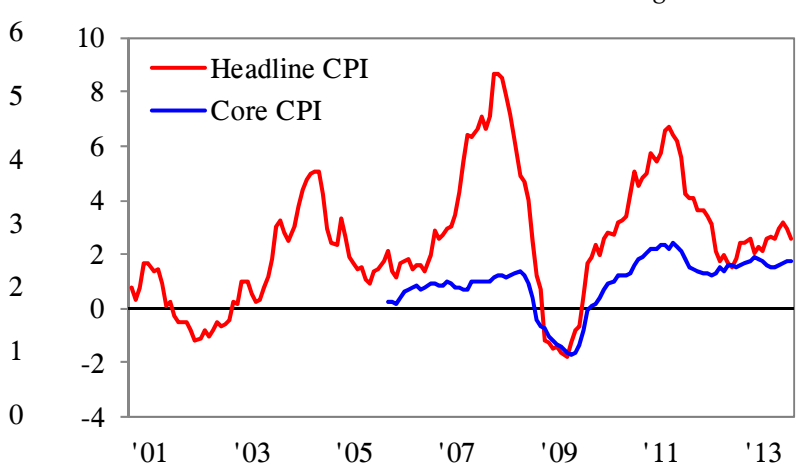


Figure 31. Country Detail: South Africa, Mexico, and Indonesia

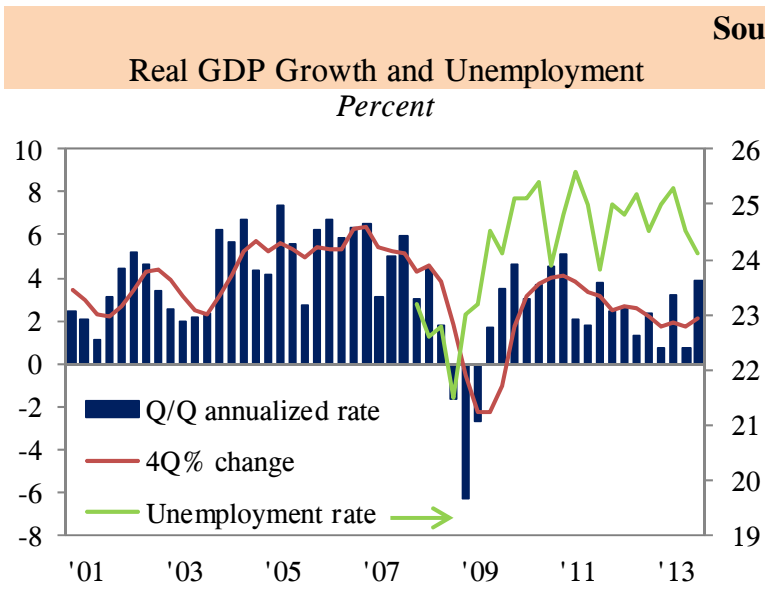

Inflation

Year-over-Year Percent Change

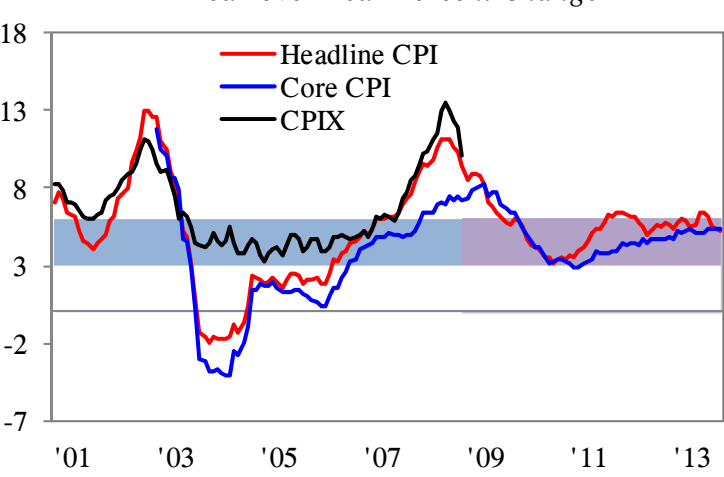

Note: The current inflation target is $3-6 \%$ for headline CPI. Prior to 2009, the CPIX (which excludes mortgage rates) was targeted at the same range.

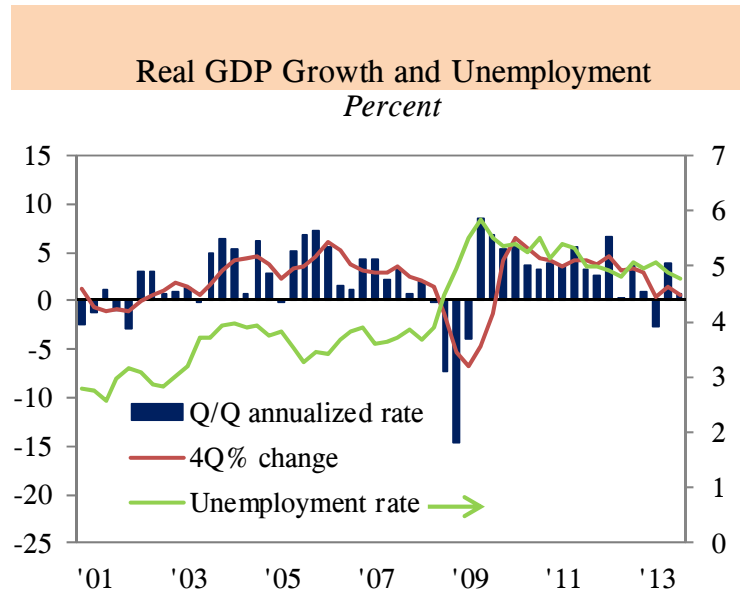

\section{Mexico}

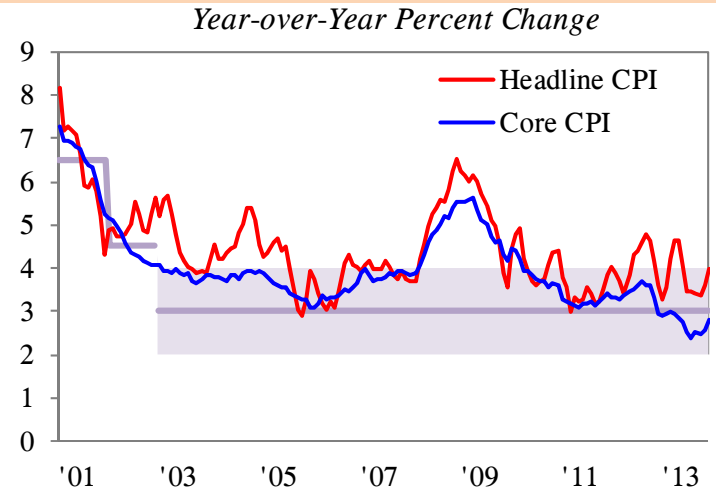

Note: The current inflation target is $3( \pm 1) \%$.

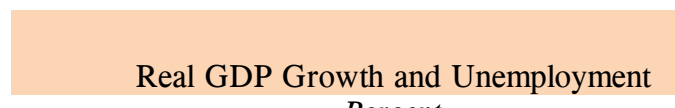
Percent

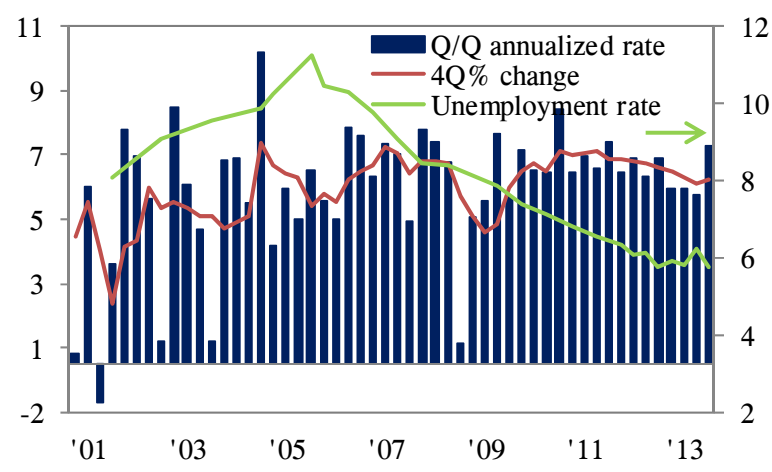

Inflation

Year-over-Year Percent Change

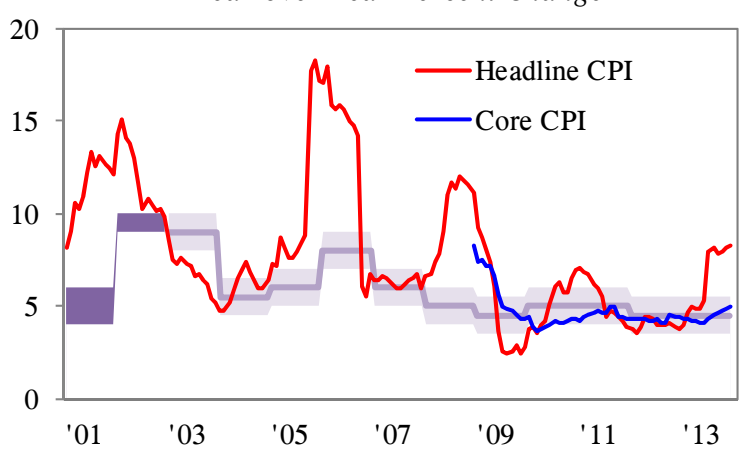

Note: The current inflation target is $4.5( \pm 1) \%$. 
Figure 32. Country Detail: South Korea and Turkey

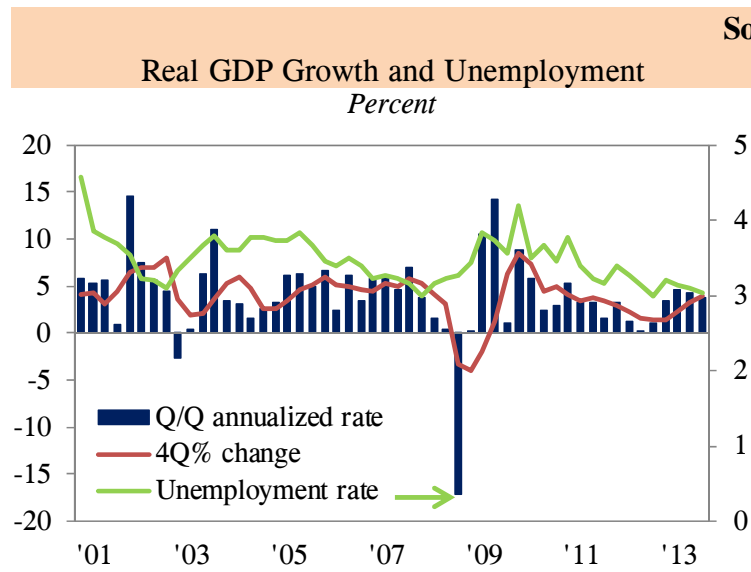

South Korea

hemployment

Inflation

Year-over-Year Percent Change

5

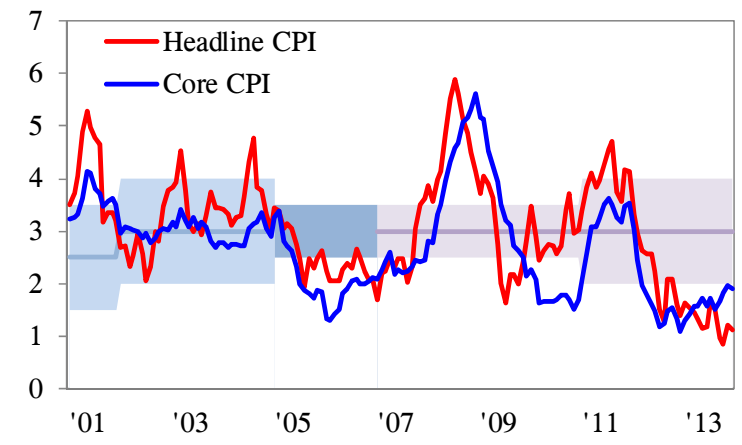

Note: The current inflation target is $2.5-3.5 \%$ for the headline

CPI. Prior to 2007, the core CPI was targeted.

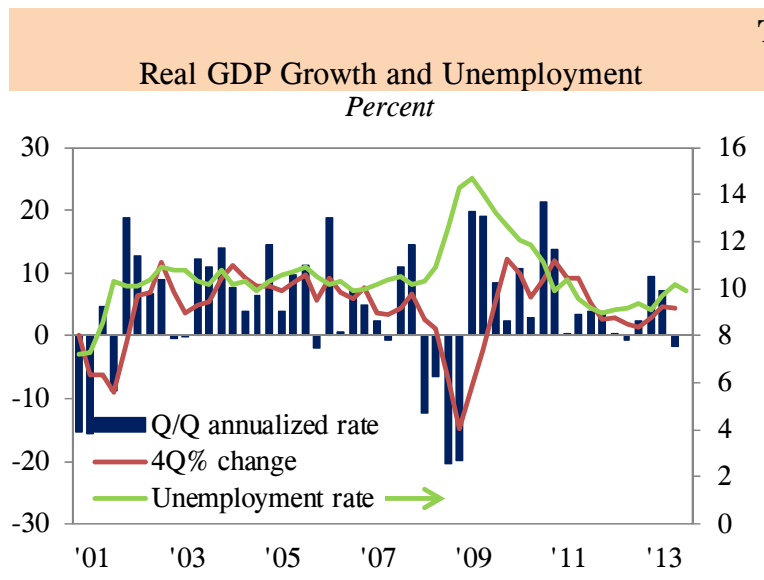

\section{Turkey}

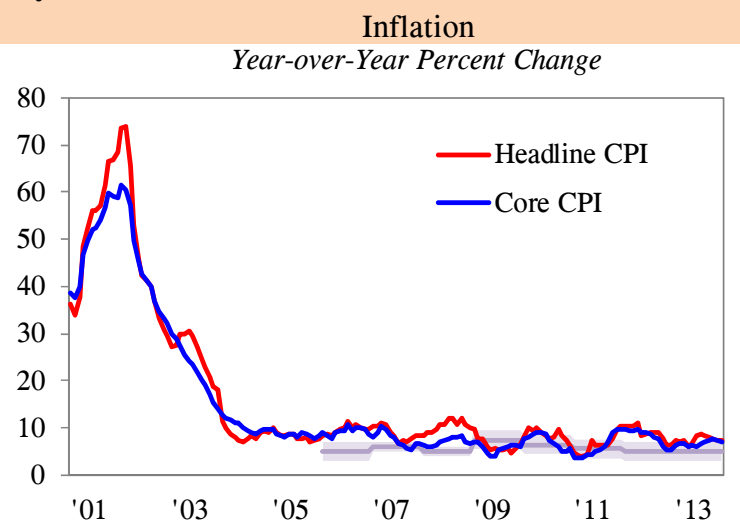

Note: The current inflation target is $5( \pm 2) \%$. 


\section{General Bibliographic References}

Artis, Michael J., Massimiliano Marcellino, and Tommaso Proietti (2004): "Dating Business Cycles: A Methodological Contribution with an Application to the Euro Area.” Oxford Bulletin of Economics and Statistics 66(4):537-565.

Baxter, Michael A. (1998): “Interpolating Annual Data into Monthly or Quarterly Data.” GSS Methodology Series No. 6, Office for National Statistics.

Boot, J.C.G., W. Feibes, and J.H.C. Lisman (1967): "Further Methods of Derivation of Quarterly Figures from Annual Data.” Journal of the Royal Statistical Society, Series C (Applied Statistics) 16(1):65-75.

Bry, G. and C. Boschan. (1971): Cyclical Analysis of Time Series: Selected Procedures and Computer Programs. New York, New York: National Bureau of Economic Research (NBER).

Burns, A.F. and W.C. Mitchell. (1946): Measuring Business Cycles. New York, New York: National Bureau of Economic Research (NBER).

Chamberlin, Graeme (2010): “Methods Explained: Temporal Disaggregation.” Economic and Labor Market Review 4(11):106-121.

Chen, B. and S.H. Andrews (2008): "An Emprirical Review of Methods for Temporal Distribution and Interpolation in the National Accounts.” Survey of Current Business 3137.

Chow, G. C. and A. Lin (1971): "Best Linear Unbiased Interpolation, Distribution and Extrapolation of Time Series by Related Series.” Review of Economics and Statistics 53:372-375.

Crone, T.M. (2006): "What a New Set of Indexes Tells Us About State and National Business Cycles.” Business Review (Q1):11-24.

Darvas, Z. (2012): "Real Effective Exchange Rates for 178 Countries: A New Database." Bruegel Working Paper 2012/06. (http://www.bruegel.org/publications/publicationdetail/publication/716-real-effective-exchange-rates-for-178-countries-a-new-database/).

Denton, F. T. (1971): “Adjustment of Monthly or Quarterly Series to Annual Totals: An Approach Based on Quadratic Minimization.” Journal of the American Statistical Association 66:92-102.

Greville, T.N.E. (1967): "Spline Functions, Interpolation, and Numerical Quadrature.” in Mathematical Methods for Digital Computers. New York: Wiley.

Grossman, Valerie, Adrienne Mack, and Enrique Martínez-García (2014): “A Contribution to the Chronology of Turning Points in Global Economic Activity (1980-2012).” Globalization and Monetary Policy Institute Working Paper Series 169.

Harding, D. and A. Pagan (2002): "Dissecting the Cycle: A Methodological Investigation." Journal of Monetary Economics 49(2):365-381.

IMF. (2004): Produce Price Index Manual. Theory and Practice. International Monetary Fund, publication services. (http://www.imf.org/external/np/sta/tegppi/).

IMF (2010): "Rebalancing Growth." in World Economic Outlook (WEO), April 2010. (http://www.imf.org/external/pubs/ft/weo/2010/01/index.htm)

IMF (2013): “World Economic Outlook Database-WEO Groups and Aggregates Information.” (http://www.imf.org/external/pubs/ft/weo/data/assump.htm). 
Loretan, M. (2005): "Indexes of the Foreign Exchange Value of the Dollar.” Federal Reserve Bulletin (Winter):1-8. (http://www.federalreserve.gov/pubs/bulletin/2005/winter05_index.pdf).

Mack, Adrienne and Enrique Martínez-García (2011 (Revised December 2013)): "A CrossCountry Quarterly Database of Real House Prices: A Methodological Note.” Federal Reserve Bank of Dallas, Globalization and Monetary Policy Institute Working Paper No. 99.

Martínez-García, E. and J Søndergaard (2009): "Investment and Trade Patterns in a Sticky-Price, Open-Economy Model." in The Economics of Imperfect Markets. The Effect of Market Imperfections on Economic Decision-Making, edited by Giorgio Calcagnini and Enrico Saltari. Series: Contributions to Economics ed. Heidelberg: Springer (Physica-Verlag).

Martínez-García, E. and M.A. Wynne (2010): “The Global Slack Hypothesis.” Staff Paper (10).

McGuirk, A.K. (1986): "Measuring Price Competitiveness for Industrial Country Trade in Manufactures.” IMF Working Paper 87/34.

Nielsen, L. (2011): "Classifications of Countries Based on their Level of Development: How it is Done and How it Could be Done.” IMF Working Paper 11/31.

OECD (2011): "Sources and Methods of the OECD Economic Outlook." (http://www.oecd.org/eco/outlook/aggregationmethods.htm; http://www.oecd.org/eco/outlook/growthratesineodb.htm).

Stock, James H. and Mark W. Watson (2010): "Indicators for Dating Business Cycles: CrossHistory Selection and Comparisons." American Economic Review, Papers and Proceedings 100(2):16-19.

UNDP (2013): "Human Development Report 2013. The Rise of the South: Human Progress in a Diverse World.” (http://www.undp.org/content/undp/en/home/librarypage/hdr/humandevelopment-report-2013/; http://hdr.undp.org/en/media/HDR2013_EN_Statistics.pdf).

World Bank (2013): "New Country Classifications \& How we Classify Countries." (http://data.worldbank.org/news/new-country-classifications; http://data.worldbank.org/about/country-classifications). 


\section{Appendix A. Country Definition}

We define countries in DGEI by the boundaries of independent nation-states, but a few overseas territories and multi-country unions may have to be considered due to their economic relevance or because of their separate status in the reported data.

- DGEI treats countries individually - separately from the political, currency, and customs unions to which they belong or have belonged—but the data of these supranational entities may still be used on an occasional basis whenever a time series needs to be extended back in time further than what we find in the available country sources.

- DGEI defines countries by their internationally recognized boundaries, but in some cases the data reported by the countries themselves does not include some of the dependencies and overseas territories with special status. We do not attempt to correct for that.

The following list indicates the most substantive issues arising with the implementation of the independent nation-state definition of a country that we have adopted:

\section{Political, Currency, and Customs Unions}

1. Southern African Customs Union (SACU) is the oldest surviving customs union in the world — started in 1910. It currently includes Botswana, Lesotho, Namibia, South Africa, and Swaziland. Sometimes data may be available for SACU, but not for its member countries. Note: Namibia got its independence from South Africa in 1990 and only after that it joined SACU as a separate country.

2. Belgium and Luxembourg was the most enduring currency union in Europe (since the end of World War II) until these two countries joined an even larger currency union with the adoption of the euro. Most data prior to 1997 is reported for both countries jointly.

3. From the former Socialist Republic of Yugoslavia, Croatia, Macedonia, and Slovenia got their independence in 1991. Bosnia and Herzegovina declared its independence in 1992. Serbia and Montenegro formed the Federal Republic of Yugoslavia in 1992 after the effective dissolution of the Socialist Republic of Yugoslavia during the Yugoslav Wars in 1991-92. The Federal Republic of Yugoslavia was renamed Serbia and Montenegro in 2003. Montenegro became independent in 2006 ending its union with Serbia.

4. The dissolution of the Soviet Union (U.S.S.R.) in 1991 led to the formation of 15 newlyindependent states: The Russian Federation, Ukraine, Belarus, Uzbekistan, Kazakhstan, Georgia, Azerbaijan, Lithuania, Moldavia, Latvia, Kyrgyzstan, Tajikistan, Armenia, Turkmenistan, and Estonia. The Russian Federation promoted the formation of the Commonwealth of Independent States (CIS) in 1993 of which 8 former Soviet Union republics are part: Armenia, Azerbaijan, Belarus, Kazakhstan, Kyrgyzstan, Moldavia, Russia, Tajikistan, and Uzbekistan. 


\section{Overseas Territories and Special Administrative Regions}

1. Macao was a Portuguese overseas territory in China, similar to what Hong Kong was for Great Britain. Great Britain transferred sovereignty over Hong Kong to China in 1997 while Portugal transferred sovereignty over Macao in 1999. Since then both have become Special Administrative Regions. Data for both is reported nowadays separately from mainland China, and generally was excluded from the data reported by Portugal and Great Britain before the transfer of sovereignty.

2. Bermuda is the largest overseas territory of Great Britain. It has its own currency (the Bermudian dollar) separate from the British pound and its statistics are generally not included among those of Great Britain.

3. Aruba has been autonomous since 1986 as part of the extinct Netherlands Antilles (dissolved in 2010), and remains part of the Kingdom of the Netherlands to this day. The Netherlands Antilles included Aruba, Curacao, Saint Maarten, Bonaire, Saba, and Saint Eustatius. Aruba has a separate currency (the Aruban florin), and its statistics are generally not included among those of the Netherlands.

4. Greenland and the Faroe Islands are autonomous territories within the Kingdom of Denmark. Greenland has no separate currency - it uses the Danish krone-and the Faroe Islands use the Faroese krona under a fixed page with the Danish krone. Its statistics may not always be counted among those of Denmark.

5. New Caledonia is an overseas collectivity of France. It has its own currency, the CFP franc-pegged since the 1960s to the French franc and later the euro. French Guiana is the largest overseas department and region of France, and as an integral part of France used the French franc and later the euro as its currency. Often their data is reported separately from that of metropolitan France. 


\section{Appendix B. An Assessment of the Quadratic-Match Method for Interpolation}

Interpolation methods are used for the conversion of low frequency to high frequency data-that is, for temporal disaggregation whenever no additional source of high frequency data is available to facilitate the conversion. ${ }^{11}$ Interpolation can be defined as fitting a curve over measurements made at the sampled periods to infer unsampled quarters with which they must conform. Standard interpolating methods without related data include constant piecewise, linear, polynomial (quadratic, cubic,...), and spline, among others.

There are multiple interpolation methods which can be used for temporal disaggregation, but there is not necessarily one single method that is superior to the others. Different methods tend to emphasize different aspects of the data, so a given interpolation technique may turn out to be best in some applications but not in others depending on the features of the interpolated data that are deemed most important.

Our preferred choice for interpolation is to use the quadratic-match average (or the quadraticmatch sum) method to interpolate the data to a monthly frequency (quarterly frequency for real GDP only). Interpolating with a quadratic function introduces a systematic source of serial correlation in the regressors because data points are related to each other by a quadratic polynomial. This must be taken into account when using time series with interpolated data for the purpose of statistical inference-that is, standard errors should be made robust to autocorrelation in hypothesis testing.

Therefore, it is important to discuss the merits of the implementation of the quadratic-match interpolation method that is used as the default for DGEI. To do so, we contrast explicitly the performance of the quadratic-match method against a conventional alternative based on cubic splines (see, e.g., Greville (1967)) along four key dimensions-local/global behavior of the procedure, smoothness/ruggedness of the series, shape-preservation/monotonicity/natural-shape features of the data, and accuracy-of-fit/parsimony. For a complementary assessment of the quadratic-match method along the same lines, see the discussion in Mack and Martínez-García (2011 (Revised December 2013)).

\footnotetext{
${ }^{11}$ Different econometric disaggregation techniques, such as the Denton (1971) and Chow and Lin (1971) approaches to cite just two of the most popular methods, can also be used for quarterization. These techniques interpolate the low frequency data at quarterly frequency using related indicator variables that are reported themselves at quarterly frequency. We generally do not have access to quarterly indicators that can be used with the available data for temporal disaggregation of the series in the DGEI.
} 


\section{Appendix B.1. Implementation of the Interpolating Methods}

A. Quadratic-match method:

We employ a local quadratic method where the average (or the sum) is matched to the sourced low frequency data. The quadratic-match interpolation fits a local parabola to three

points for each low frequency observation, then uses this polynomial to fill in all observations of the high frequency (quarterly) series associated with the data for the observed period. One point before and one point after the period being interpolated are used to provide the set of three points needed for the quadratic polynomial. For end points, both points must be taken from the side where data is available.

B. Cubic-spline method:

The cubic spline that we use for comparison assigns each observation of the low frequency time series to the last quarter associated with the low frequency period, then locates all intermediate points fitting a natural cubic spline connecting those observations. Each segment of the curve is represented by a cubic polynomial. Adjacent segments of the curve have the same level, first derivative, and second derivative at the point where they meet. We impose the additional condition that the second derivative of the curve at the two global end points is equal to zero (the cubic-spline under this condition is referred to as the "natural" spline).

C. Partial-sum cubic-spline method:

The partial-sum cubic spline method is a variant of the cubic spline method that is implemented on flow data that has been previously accumulated to construct a stock series. In order to recover the interpolated flow data after applying the cubic spline on the partial sum, the unobserved flows are recovered from the difference in the interpolated stock data. 


\section{Appendix B.2. Features of the Interpolation}

We illustrate the performance of the quadratic-match method relative to the natural cubic-spline and the partial-sum natural cubic-spline interpolating methods with the U.S. data from the RealTime Data Set for Macroeconomists from the Federal Reserve Bank of Philadelphia. We then compare the interpolated data against the actual U.S. series on a number of the indicators in DGEI, which in this case are also observable.

Local/global behavior: An important distinction between interpolation methods is that some are global (e.g., the cubic-spline and the partial-sum cubic-spline methods) while others are local (e.g., the quadratic-match method). Global methods take into consideration all low frequency observations so that changes in any one data point (or the addition of new data) to the observed series affect all interpolated data points. Global methods generally-but not always-create smooth surfaces, but can be very sensitive to the presence of outliers or breaks in the data. The influence of outliers on the fitted interpolating function will be felt on the entire surface. Local methods, in turn, only use a fixed number of observations within the neighborhood of the interpolated data point. Local methods usually yield less smooth surfaces, but are not as sensitive to outliers, breaks in the series, and preliminary data (or data subject to significant revisions) because their effects only affect localized regions of the interpolated curve. For those reasons, preference is given to local interpolation methods in DGEI.

Smoothness/ruggedness: Excessive undulations caused by large curvature changes should be avoided-since the fitting curve changes its curvature at inflection points, these should be kept to a minimum as well. To avoid excessive and frequent changes in the curvature of the interpolating function, a $\mathrm{C}^{2}$ continuous curve can be desirable as it also implies continuous secondderivatives. The cubic-spline interpolation functions sometimes exhibit unnatural wiggles and bumps, but the proponents of the method often argue that its $C^{2}$ smoothness is nonetheless a desirable feature. In turn, $\mathrm{C}^{2}$ smoothness does not occur with the partial-sum cubic-spline or the quadratic-match method.

Given that the frequency of the observed data cannot be changed, there are two ways to vary the degree of smoothness of the interpolated data: relaxing $C^{2}$ continuity to $C^{1}$ continuity; and using polynomial interpolating functions of different order. The quadratic interpolating function ensures only $\mathrm{C}^{1}$ continuity, but this appears sufficient to interpolate the data in the applications we encounter in DGEI without smoothing out too much of the variability from quarter to quarter.

However, the interpolating curves are not constrained to be continuous at the boundaries between adjacent observed periods in the case of the quadratic-match method. The approach is better suited to situations where relatively few data points are being interpolated and the source data is fairly smooth. We find that this is the case in most of the applications we have in DGEI, so we expect this method to perform well. In turn, we find that the smoothness imposed by the cubicspline method with continuous second-derivatives may be counterfactual.

Shape-preservation/monotonicity/natural-shape features: A trade-off arises between the degree of smoothness and the property of local monotonicity (or shape-preservation). The piecewise linear interpolating function is at one extreme of the possibilities because it is continuous-with jumps 
in its first derivatives - and there is hardly any smoothness in the interpolation, but piecewise linear interpolation preserves the monotonicity of the data locally. It also preserves the shape of the data better because it avoids overshooting in the approximation, and the interpolated data is increasing, decreasing, or constant on the same intervals as the actual observed data. The infinite-order polynomial interpolating function is at the other extreme of the realm of possibilities. It is infinitely differentiable, but it generally fails to preserve the shape of the observed data. By using the quadratic-match method in DGEI, therefore, we favor the shape preservation property over greater smoothness relative to the standard cubic-spline method. ${ }^{12}$

Accuracy-of-fit/parsimony: Another one of our major goals is to strike a balance between accuracy and parsimony, which depends on the desired properties for the interpolated data (see, e.g., Baxter (1998) and Chamberlin (2010)). A third-degree (cubic) polynomial is a polynomial of the lowest degree that can display an inflection point, so it can be used (at least locally) to fit a curve that has inflection points. ${ }^{13}$ In that case, interpolation imposes the accuracy of a third-order polynomial. Our preferred method-the quadratic-match method-requires, in turn, only the accuracy of a second-order polynomial.

Our analysis of the (partial-sum) cubic-spline and the quadratic-match method in suggests that in general the accuracy gains from adopting a higher-order polynomial are not large enough to justify an additional degree in the interpolating polynomial (from quadratic to cubic). The heat maps reported in Figure 33-Figure 38 have been constructed using data on some of the indicators covered by DGEI at all available vintages for the U.S. from the Real-Time Data Set for Macroeconomists from the Federal Reserve Bank of Philadelphia, using always a constant sample size that includes the last 18 years of each quarterly vintage and the last 12 years of each monthly vintage. ${ }^{14}$ The accuracy of the interpolation methods is evaluated with the relative mean-squared error (RMSE), that is, the ratio of the mean-squared error with the quadraticmatch method relative to that obtained with the (partial-sum) cubic spline. The errors are computed by comparing the actual data for the U.S. for each vintage with the interpolated data derived from the aggregates.

The evidence reported here suggests that the quadratic-match method has become increasingly more accurate in order to match the patterns of the data. It is interesting to observe that the pattern has undergone significant changes over time, but also that the results are robust to revisions within the three main periods that we detect in Figure 33-Figure 38 across different variables (prior to 1973, between 1973 and 1991, and since 1991). Moreover, the accuracy in levels and growth rates reported in the heat maps shows the quadratic-match method performance is not significantly different than that of the cubic spline approximation since the mid-1970s and beats that of the cubic spline since the early 1990s. In this regard, we can say not only that the method is fairly accurate for our purposes but also that the goodness-of-fit attained is largely robust to subsequent data revisions.

\footnotetext{
${ }^{12}$ The quadratic-match and cubic-spline methods do not guarantee that the curve fitted would satisfy non-negativity, though. In other words, while all data points observed are positive, it is possible that some of the interpolated data points may become negative.

${ }^{13}$ We say that an interpolation method has the accuracy of a polynomial function of degree $n$ if the method accurately interpolates the data when it lies on a curve of a polynomial of degree $n$ or smaller.

${ }^{14}$ Given that we apply the same procedure to the series in levels and in quarter-over-quarter growth rates, we do not consider the first four observations of the series in order to ensure that the sample size is the same in all cases.
} 
Figure 33. Accuracy of the Quadratic-match Relative to the Partial-sum Cubic Spline with the U.S. GDP

MSE, levels

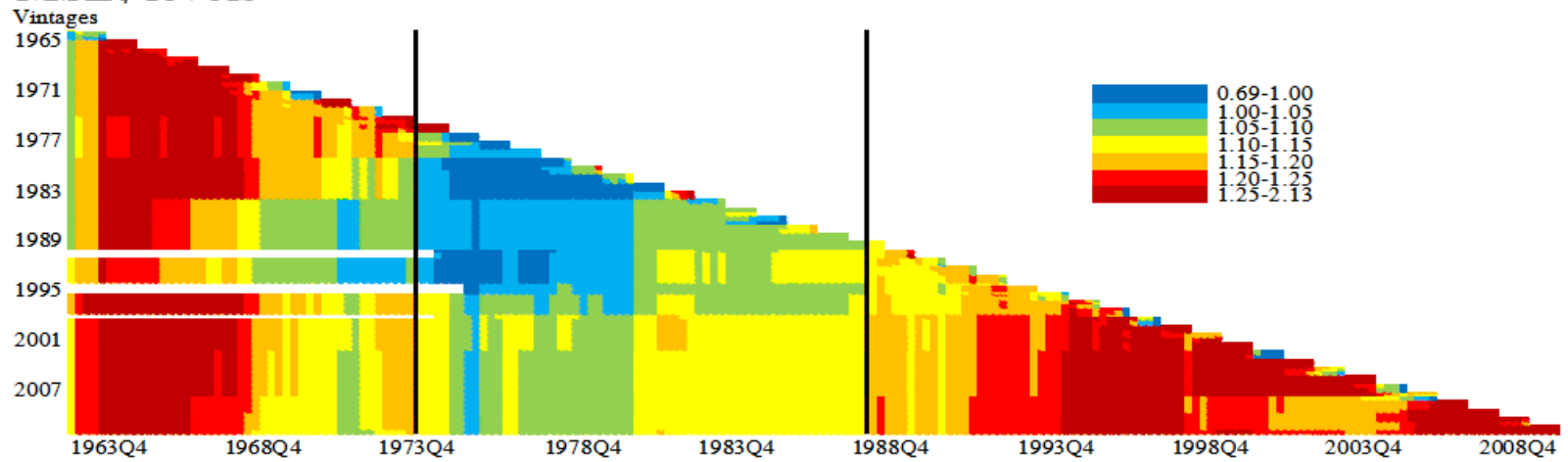

MSE, growth rates

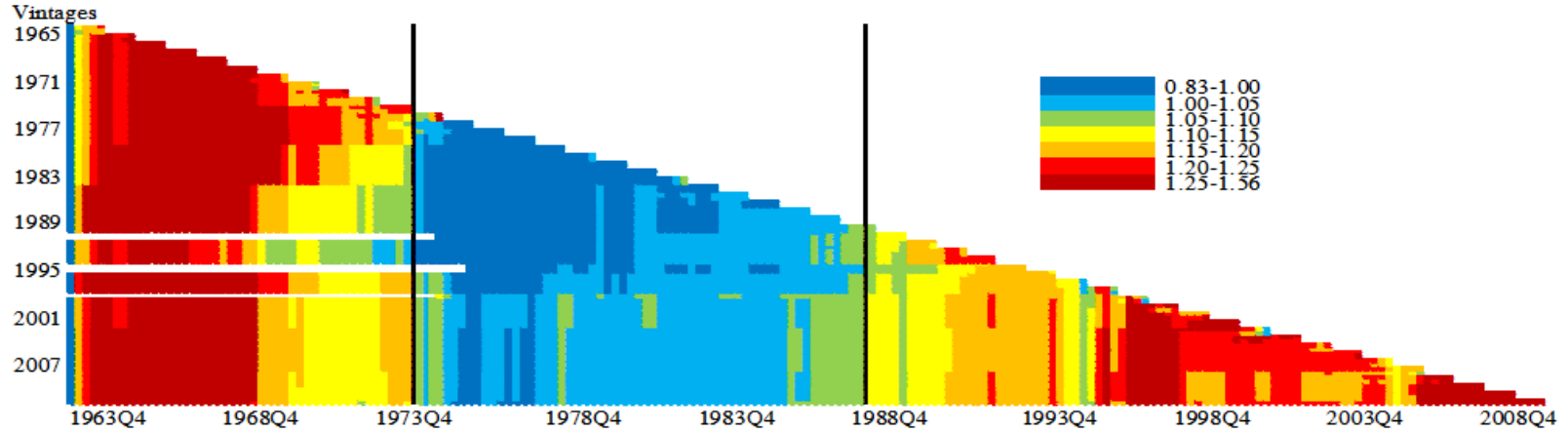

Source: U.S. Bure au of Economic Analysis, National Income and Product Accounts of the United States, Real-Time Database of the Federal Reserve Bank of Philadelphia, and author's calculations. 
Figure 34. Accuracy of the Quadratic-match Relative to the Partial-sum Cubic Spline with the U.S. PCE

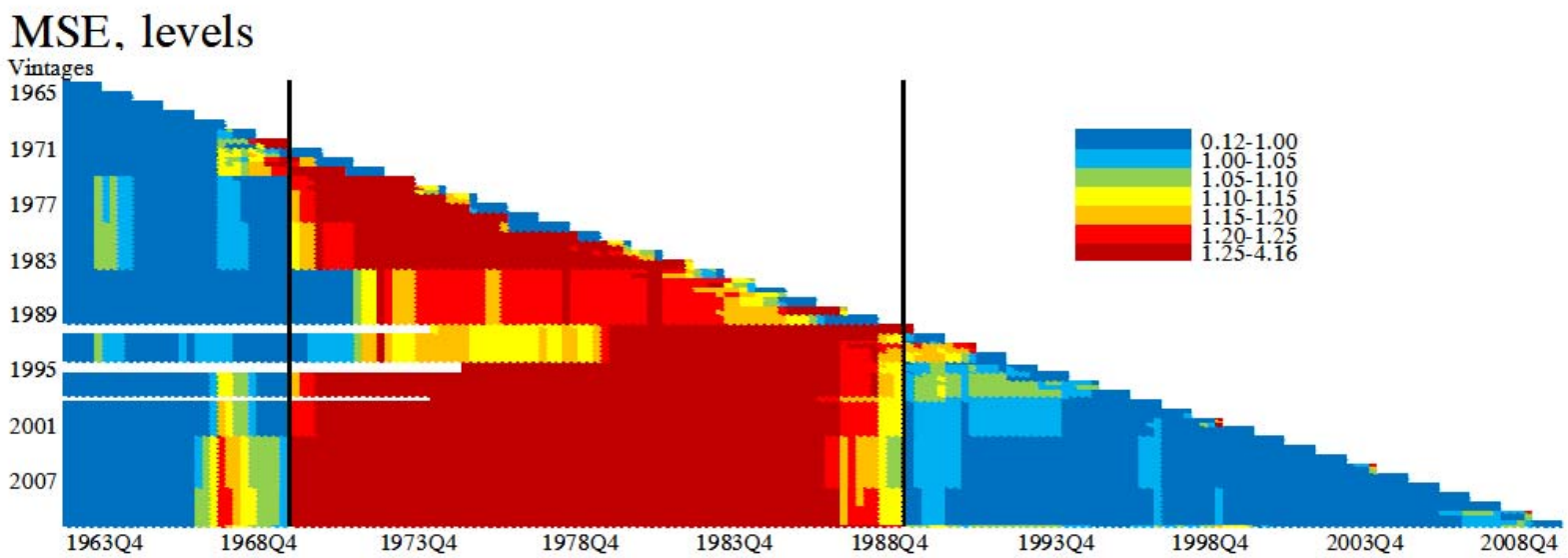

MSE, growth rates

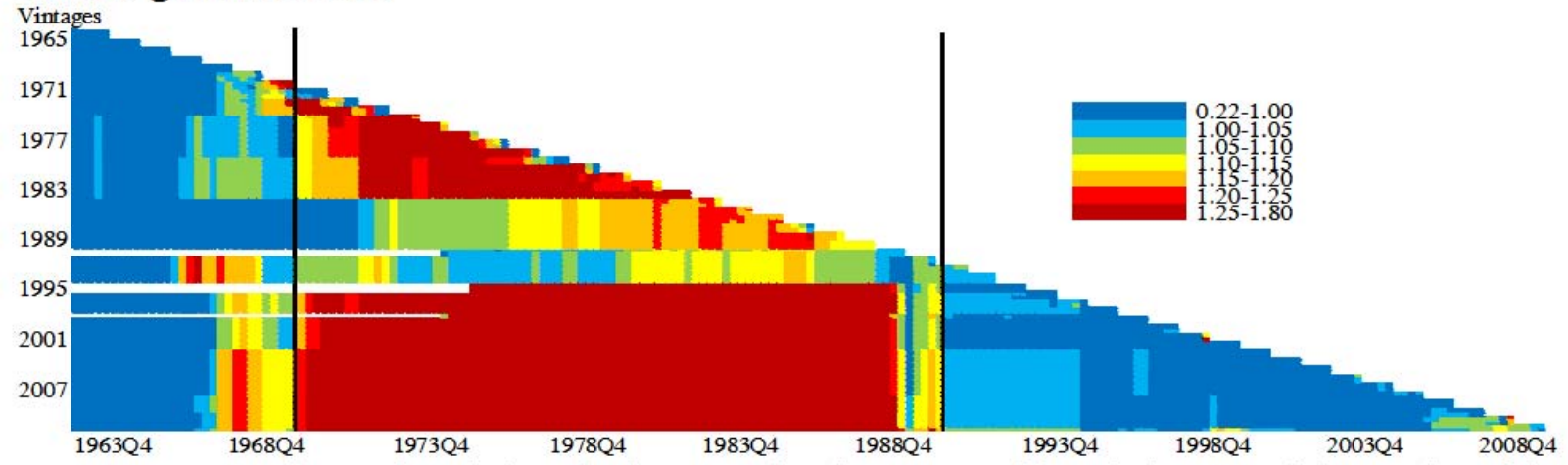

Source: U.S. Bureau of Economic Analysis, National Income and Product Accounts of the United States, Real-Time Database of the Federal Reserve Bank of Philadelphia, and author's calculations. 
Figure 35. Accuracy of the Quadratic-match Relative to the Partial-sum Cubic Spline with the U.S. IP

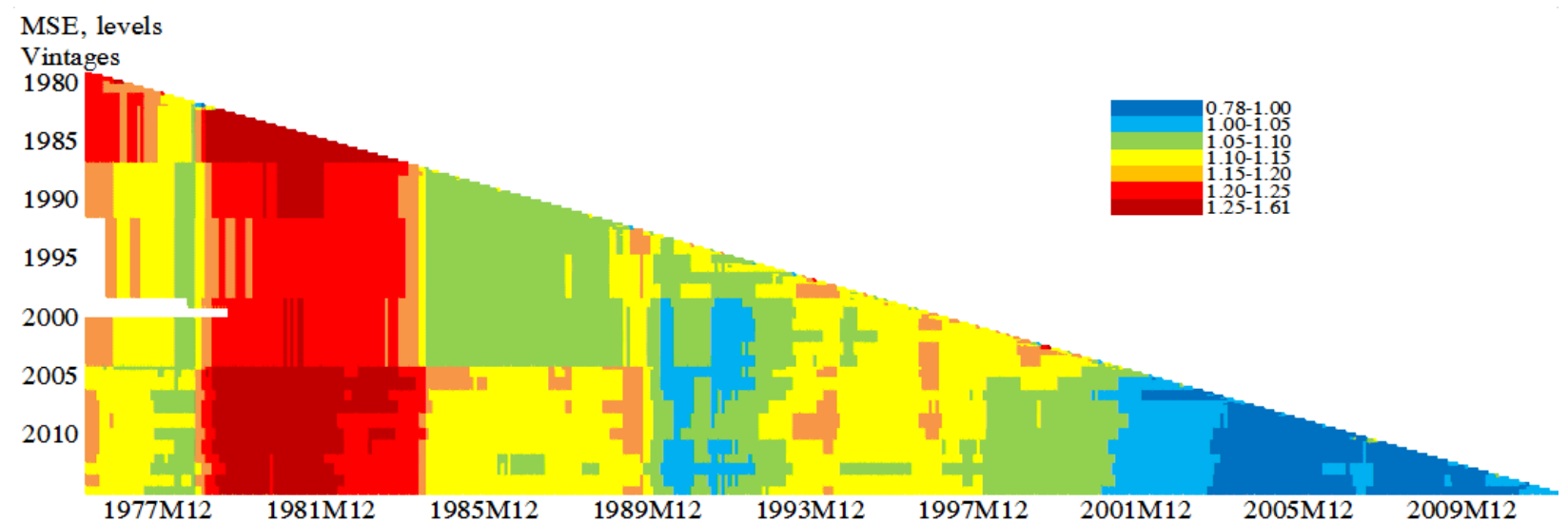

MSE, growth rates

Vintages

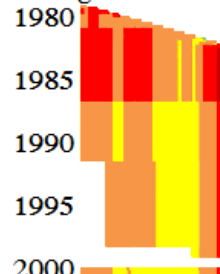

2000

2005

2010
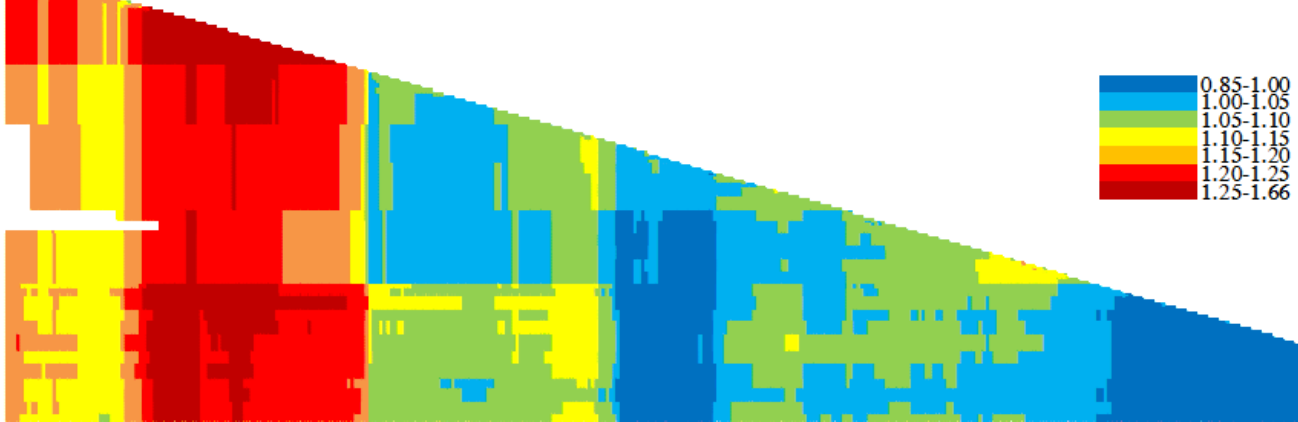

Source: U.S. Bureau of Economic Analysis, National Income and Product Accounts of the United States, Real-Time Database of the Federal Reserve Bank of Philadelphia, and author's calculations. 
Figure 36. Accuracy of the Quadratic-match Relative to the Partial-sum Cubic Spline with the U.S. CPI

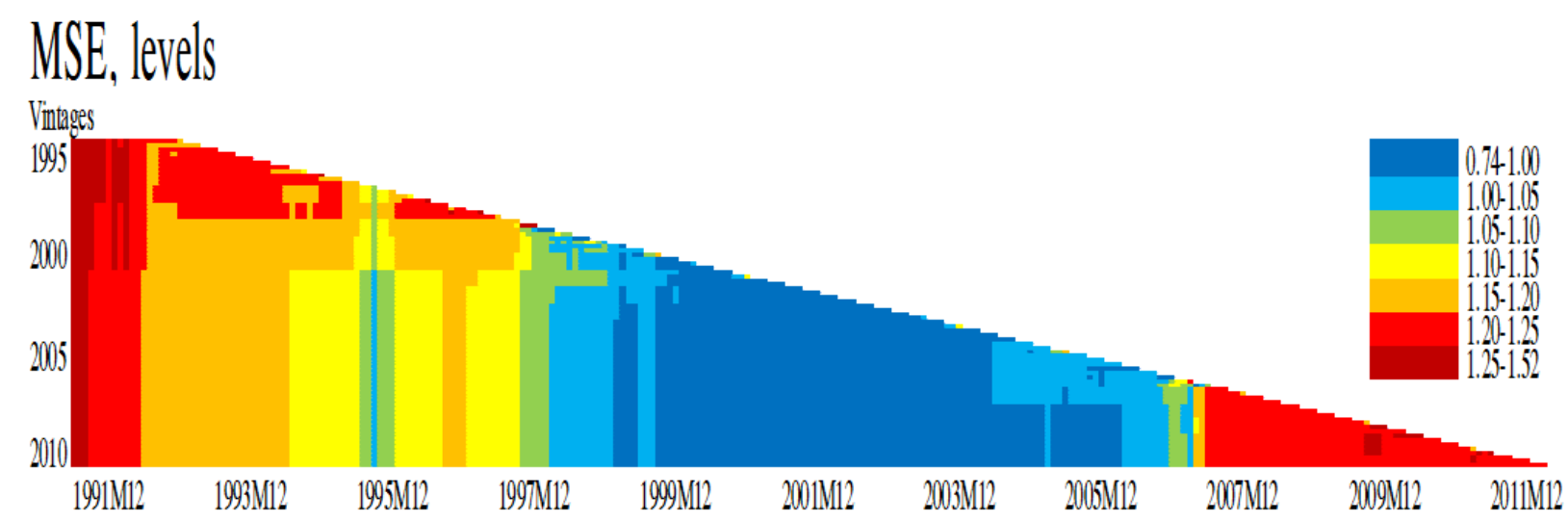

\section{MSE, growth rates}

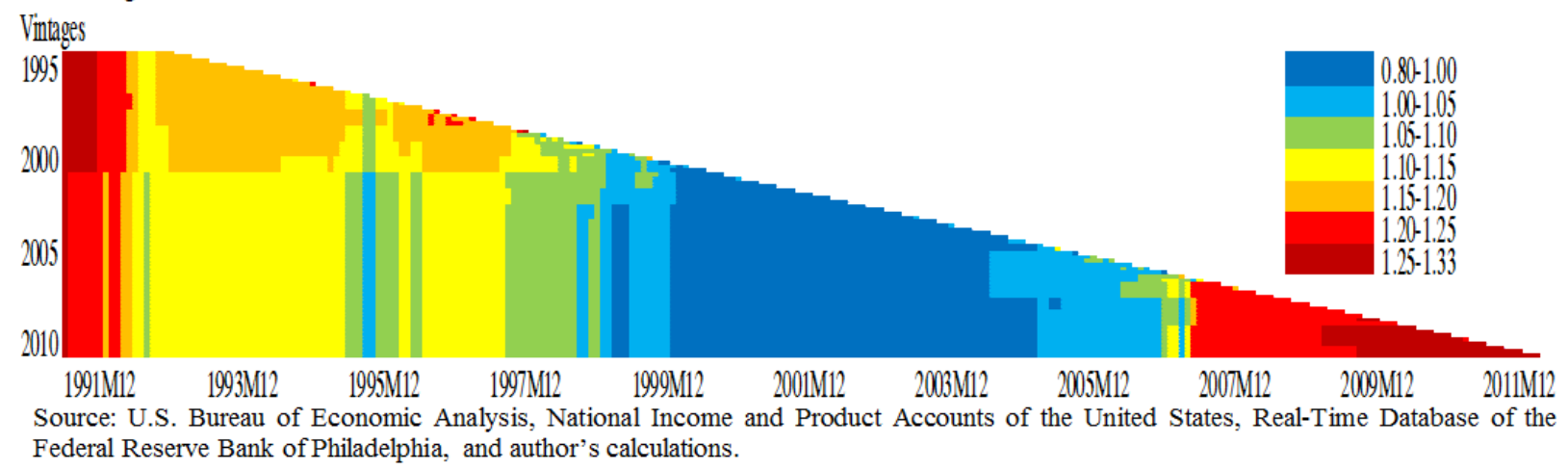


Figure 37. Accuracy of the Quadratic-match Relative to the Partial-sum Cubic Spline with the Core CPI

MSE, levels

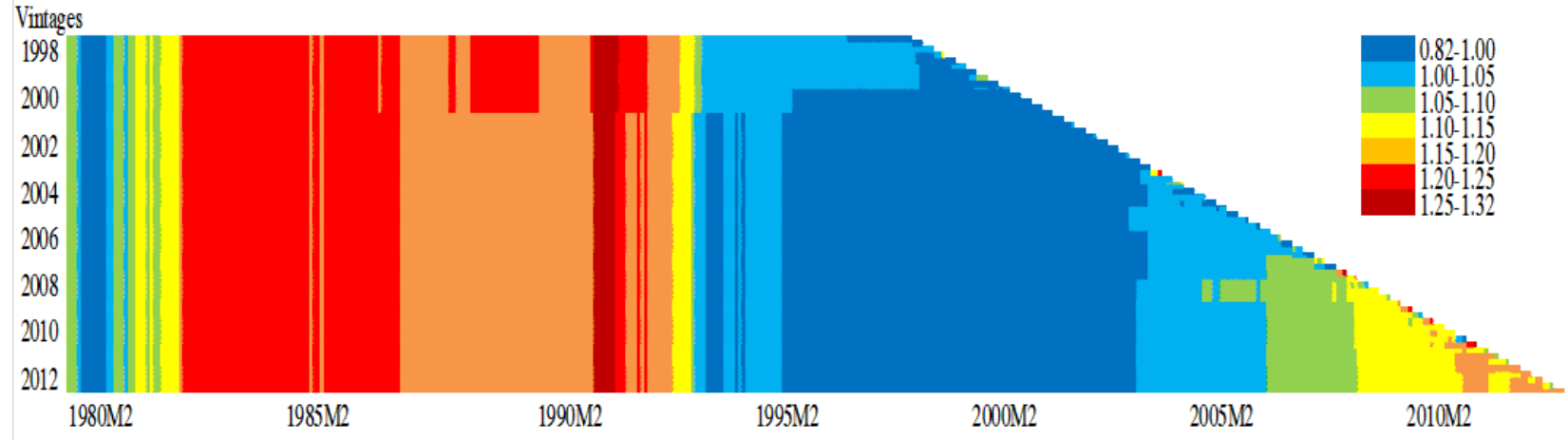

MSE, growth rates

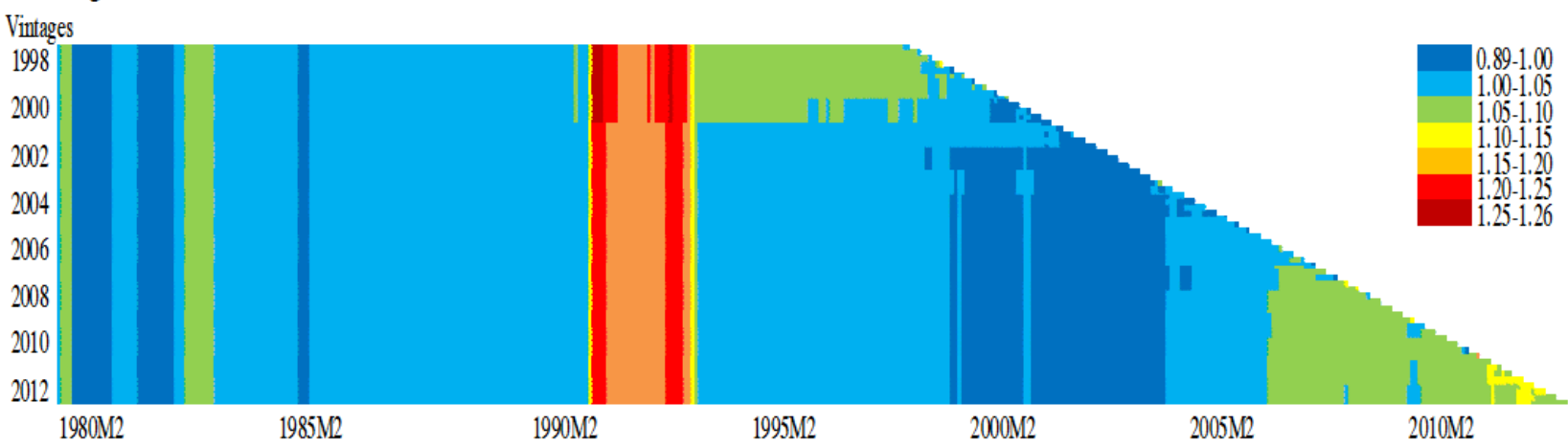

Source: U.S. Bureau of Economic Analysis, National Income and Product Accounts of the United States, Real-Time Database of the Federal Reserve Bank of Philadelphia, and author's calculations. 
Figure 38. Accuracy of the Quadratic-match Relative to the Partial-sum Cubic Spline with the PPI

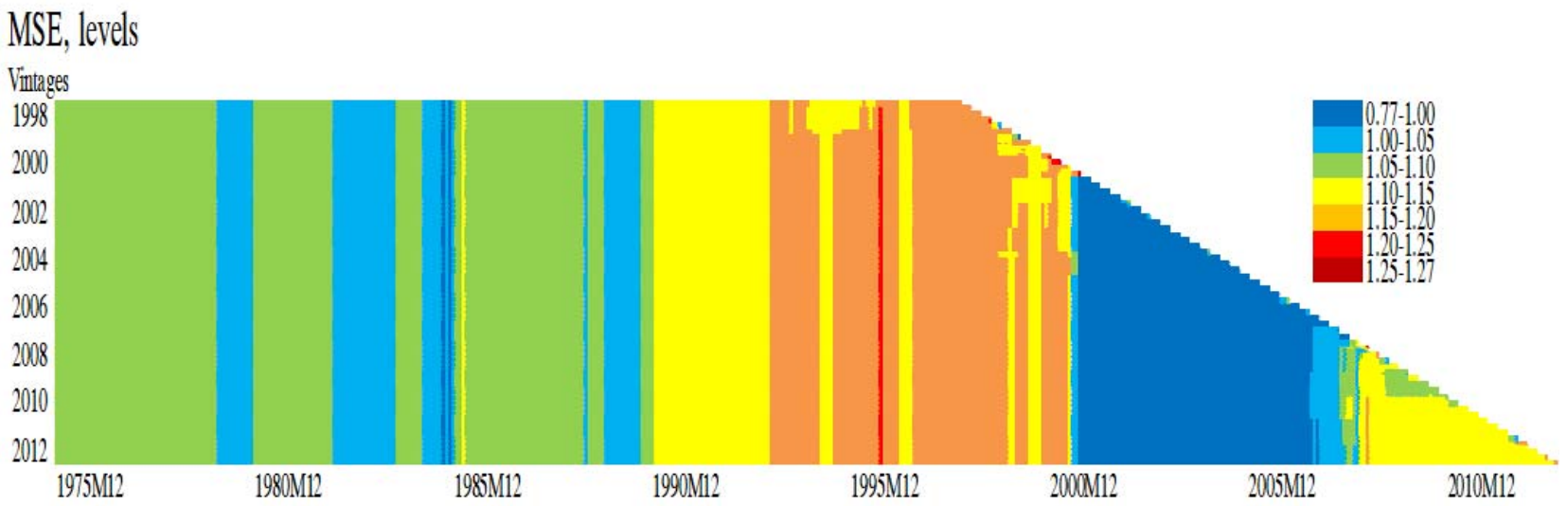

MSE, growth rates
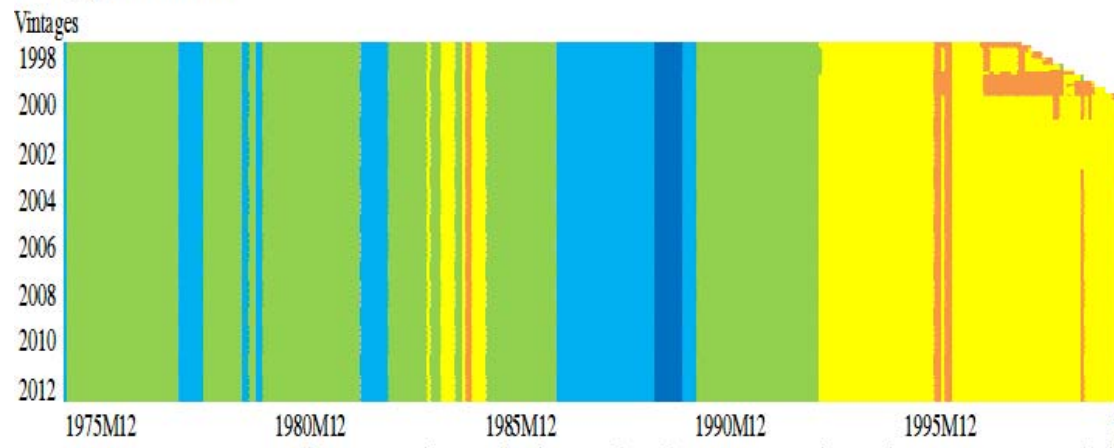

ource: U.S. Bureau of Economic Analysis, National Income

Federal Reserve Bank of Philadelphia, and author's calculations. 


\section{Appendix C. Country Sources}

Table 7. Country Sources on Real Gross Domestic Product

\begin{tabular}{|c|c|c|c|}
\hline Country & Data Description & Source & Start Date \\
\hline United States & GDP in chained 2009 dollars & Bureau of Economic Analysis & Q1-1947 \\
\hline United Kingdom & GDP in chained 2010 pounds & Office for National Statistics & Q1-1955 \\
\hline \multirow[t]{2}{*}{ Austria } & GDP in chained 2005 euros & $\begin{array}{l}\text { Austrian Institute of Economic } \\
\text { Research/Statistik Austria }\end{array}$ & Q1-1988 \\
\hline & GDP in chained 2005 euros & OECD & Q1-1960 \\
\hline \multirow[t]{2}{*}{ Belgium } & GDP in chained 2011 euros & Banque Nationale de Belgique & Q1-1995 \\
\hline & GDP in chained 2009 euros & OECD & Q1-1960 \\
\hline France & GDP in chained 2005 euros & $\begin{array}{l}\text { Institut National de la } \\
\text { Statistique/Economique }\end{array}$ & Q1-1949 \\
\hline Germany & GDP in chained 2005 euros & Deutsche Bundesbank & Q1-1970 \\
\hline \multirow[t]{2}{*}{ Italy } & GDP in chained 2005 euros & Istituto Nazionale di Statistica & Q1-1981 \\
\hline & GDP in chained 2005 euros & OECD & Q1-1960 \\
\hline Netherlands & GDP in chained 2005 euros & Centraal Bureau voor de Statistiek & Q1-1977 \\
\hline \multirow[t]{2}{*}{ Sweden } & GDP in chained 2012 Swedish kronor & Statistiska Centralbyran & Q1-1993 \\
\hline & GDP in chained 2010 Swedish kronor & OECD & Q1-1960 \\
\hline Switzerland & GDP in chained 2005 francs & State Secretariat for Economic Affairs & Q1-1980 \\
\hline \multirow[t]{2}{*}{ Canada } & $\begin{array}{l}\text { GDP in chained } 2007 \text { Canadian } \\
\text { dollars }\end{array}$ & Statistics Canada & Q1-1981 \\
\hline & $\begin{array}{l}\text { GDP in chained } 2002 \text { Canadian } \\
\text { dollars }\end{array}$ & OECD & Q1-1960 \\
\hline Japan & GDP in chained 2005 yen & Cabinet Office of Japan & Q1-1980 \\
\hline Greece & GDP in chained 2005 euros & $\begin{array}{l}\text { Statistical Office of the European } \\
\text { Communities }\end{array}$ & Q1-1995 \\
\hline \multirow[t]{2}{*}{ Portugal } & GDP in chained 2006 euros & Instituto Nacional de Estatística & Q1-1995 \\
\hline & GDP in chained 2006 euros & OECD & Q1-1960 \\
\hline \multirow[t]{2}{*}{ Spain } & GDP in chained 2008 euros & Instituto Nacional de Estadística & Q1-1995 \\
\hline & GDP in chained 2008 euros & OECD & Q1-1960 \\
\hline Turkey & GDP in 1998 Turkish lira & Turkish Statistical Institute & Q1-1987 \\
\hline Australia & $\begin{array}{l}\text { GDP in chained Q3:2011-Q2:2012 } \\
\text { Australian dollars }\end{array}$ & Australian Bureau of Statistics & Q3-1959 \\
\hline South Africa & GDP in 2005 rand & South African Reserve Bank & Q1-1960 \\
\hline Argentina & GDP in 1993 pesos & $\begin{array}{l}\text { Min de Economía y Obras y Servicios } \\
\text { Públicos }\end{array}$ & Q1-1993 \\
\hline Brazil & GDP in chained 1995 reais & $\begin{array}{l}\text { Instituto Brasileiro de Geografia e } \\
\text { Estatística }\end{array}$ & Q1-1990 \\
\hline Chile & GDP in chained 2008 Chilean pesos & Banco Central de Chile & Q1-1986 \\
\hline \multirow[t]{2}{*}{ Colombia } & GDP in chained 2005 pesos & $\begin{array}{l}\text { Departamento Administrativo Nacional } \\
\text { de Estadísticas }\end{array}$ & Q1-2000 \\
\hline & GDP in 2005 pesos* & World Bank & 1960 \\
\hline Costa Rica & GDP in 1991 colones & Banco Central de Costa Rica & Q1-1991 \\
\hline Mexico & GDP in 2008 new pesos & $\begin{array}{l}\text { Instituto Nacional de Estadística } \\
\text { Geografía e Informática }\end{array}$ & Q1-1980 \\
\hline Peru & GDP in 1994 new soles & Banco Central de Reserva del Perú & Q1-1980 \\
\hline
\end{tabular}




\begin{tabular}{llll} 
Country & Data Description & Source & Start Date \\
\hline Venezuela & GDP in 1997 bolivares & Banco Central de Venezuela & Q1-1997 \\
Taiwan & GDP in 2006 new Taiwan dollars & $\begin{array}{l}\text { Directorate-General of Budget } \\
\text { Accounting \& Stats }\end{array}$ & Q1-1981 \\
India & GDP in FY 2004 rupees & Central Statistical Organization, India & Q2-1996 \\
Indonesia & GDP in 2000 rupiahs & Biro Pusat Statistik & Q1-1983 \\
South Korea & GDP in chained 2005 won & Bank of Korea & Q1-1970 \\
Malaysia & GDP in 2005 ringgit & Department of Statistics, Malaysia & Q1-1991 \\
Philippines & GDP in 2000 pesos & National Statistical Coordination Board & Q1-1981 \\
Thailand & GDP in 1988 baht & National Economic and Social & Q1-1993 \\
Nigeria & GDP in 1990 naira & Development Board & \\
& GDP at purchaser's prices in 1990 & National Bureau of Statistics, Nigeria & Q1-2007 \\
Bulgaria & naira* & Statistics/CBN & 1981 \\
Russia & GDP in chained 2005 leva & National Statistical Institute & Q1-1997 \\
China & GDP in chained 2008 rubles & Federal State Statistics Service & Q1-1995 \\
& GDP in 2000 yuan & China National Bureau of Statistics & Q1-1992 \\
Czech Republic & GDP in 1990 yuan* & China National Bureau of Statistics & 1978 \\
Hungary & GDP in chained 2005 Czech koruna & Czech Statistical Office & Q1-1996 \\
Poland & GDP in chained 2005 zloty & Central Statistical Office & Q1-1995
\end{tabular}

Note: * Annual data interpolated using quadratic-match average 
Table 8. Country Sources on Industrial Production

\begin{tabular}{|c|c|c|c|}
\hline Country & Data Description & Source & Start Date \\
\hline United States & IP & Federal Reserve Board & Jan-1921 \\
\hline United Kingdom & IP excluding construction & Office for National Statistics & Jan-1968 \\
\hline Austria & IP: Industry excluding construction & Statistik Austria & Jan-1960 \\
\hline \multirow[t]{2}{*}{ Belgium } & IP: Industry excluding construction & $\begin{array}{l}\text { Statistical Office of the European } \\
\text { Communities }\end{array}$ & Jan-2000 \\
\hline & IP excluding construction & OECD & Jan-1960 \\
\hline France & IP excluding construction & $\begin{array}{l}\text { Institut National de la } \\
\text { Statistique/Economique }\end{array}$ & Jan-1970 \\
\hline Germany & $\begin{array}{l}\text { IP: Total industry excluding } \\
\text { construction }\end{array}$ & Deutsche Bundesbank & Jan-1952 \\
\hline Italy & $\begin{array}{l}\text { IP: Total industry excluding } \\
\text { construction }\end{array}$ & Istituto Nazionale di Statistica & Jan-1980 \\
\hline Netherlands & IP excluding construction & OECD & Jan-1960 \\
\hline Sweden & IP & OECD & Jan-1960 \\
\hline Switzerland & $\begin{array}{l}\text { IP excluding construction, mining, } \\
\text { and quarrying* }\end{array}$ & OECD & Q1-1960 \\
\hline \multirow[t]{2}{*}{ Canada } & $\begin{array}{l}\text { IP: Manufacturing, mining, and } \\
\text { utilities }\end{array}$ & Statistics Canada & Jan-1981 \\
\hline & IP & IMF & Jan-1957 \\
\hline Japan & IP: Mining and manufacturing & Ministry of Economy, Trade \& Industry & Jan-1953 \\
\hline \multirow[t]{2}{*}{ Greece } & IP excluding construction & Hellenic Statistical Authority (ELSTAT) & Jan-1995 \\
\hline & $\begin{array}{l}\text { IP: Total industry excluding } \\
\text { construction }\end{array}$ & OECD & Jan-1962 \\
\hline Portugal & IP excluding construction & OECD & Jan-1960 \\
\hline Spain & IP excluding construction & OECD & Jan-1965 \\
\hline Turkey & IP: Total industry & Turkish Statistical Institute & Jan-1985 \\
\hline Australia & IP excluding construction* & Australian Bureau of Statistics & Q3-1974 \\
\hline South Africa & IP: Manufacturing & Statistics South Africa & Jan-1963 \\
\hline Argentina & IP & $\begin{array}{l}\text { Fundación de Investigaciones } \\
\text { Económicas Latinoamericanas }\end{array}$ & Jan-1993 \\
\hline Brazil & IP: Manufacturing & OECD & Jan-1975 \\
\hline \multirow[t]{2}{*}{ Chile } & IP & Instituto Nacional de Estadísticas & Jan-2009 \\
\hline & IP: Manufacturing & IMF & Jan-1958 \\
\hline \multirow[t]{2}{*}{ Colombia } & IP: Manufacturing & $\begin{array}{l}\text { Departamento Administrativo Nacional } \\
\text { de Estadísticas }\end{array}$ & Jan-1990 \\
\hline & IP: Manufacturing & IMF & Jan-1980 \\
\hline Costa Rica & Economic Activity: Manufacturing & Banco Central de Costa Rica & Jan-1991 \\
\hline Mexico & IP: Manufacturing & $\begin{array}{l}\text { Instituto Nacional de Estadística } \\
\text { Geografía e Informática }\end{array}$ & Jan-1980 \\
\hline \multirow[t]{2}{*}{ Peru } & IP: Manufacturing & Ministerio de la Producción & Jan-1990 \\
\hline & IP: Manufacturing & IMF & Jan-1979 \\
\hline \multirow[t]{2}{*}{ Venezuela } & IP: Manufacturing & Banco Central de Venezuela & Jan-1997 \\
\hline & IP: Crude petroleum & IMF & Jan-1957 \\
\hline Taiwan & IP: Manufacturing & Ministry of Economic Affairs & Jan-1960 \\
\hline India & IP & Central Statistical Organization, India & Jan-1971 \\
\hline
\end{tabular}




\begin{tabular}{|c|c|c|c|}
\hline Country & Data Description & Source & Start Date \\
\hline \multirow[t]{2}{*}{ Indonesia } & $\begin{array}{l}\text { IP: Manufacturing: Large and } \\
\text { medium enterprises }\end{array}$ & Biro Pusat Statistik & Jan-1993 \\
\hline & IP: Manufacturing & OECD & Jan-1986 \\
\hline South Korea & $\begin{array}{l}\text { IP: Total industry excluding } \\
\text { construction }\end{array}$ & National Statistics Office & Jan-1970 \\
\hline Malaysia & $\begin{array}{l}\text { IP: All divisions excluding } \\
\text { construction }\end{array}$ & Department of Statistics, Malaysia & Jan-1971 \\
\hline \multirow[t]{2}{*}{ Philippines } & IP: Manufacturing & National Statistics Office & Jan-1998 \\
\hline & IP: Manufacturing & IMF & Jan-1981 \\
\hline \multirow[t]{3}{*}{ Thailand } & IP: Manufacturing & Office of Industrial Economics & Jan-2000 \\
\hline & IP: Manufacturing & Central Bank of Thailand & Jan-1995 \\
\hline & IP: Manufacturing & Central Bank of Thailand & Jan-1987 \\
\hline \multirow[t]{2}{*}{ Nigeria } & IP* & Central Bank of Nigeria & Q1-2006 \\
\hline & IP* & IMF & Q1-1970 \\
\hline Bulgaria & IP & National Statistical Institute & Jan-2000 \\
\hline Russia & IP & OECD & Jan-1993 \\
\hline \multirow[t]{2}{*}{ China } & $\begin{array}{l}\text { Index of gross value added in } 1990 \\
\text { prices }\end{array}$ & China National Bureau of Statistics & Jan-1997 \\
\hline & $\begin{array}{l}\text { Real gross value added (year/year \% } \\
\text { change) }\end{array}$ & China National Bureau of Statistics & Jan-1992 \\
\hline \multirow[t]{2}{*}{ Czech Republic } & IP & Czech Statistical Office & Jan-2000 \\
\hline & IP including small enterprises & OECD & Jan-1990 \\
\hline \multirow[t]{2}{*}{ Hungary } & IP & Central Statistical Office & Jan-1993 \\
\hline & IP excluding construction & OECD & Jan-1980 \\
\hline Poland & IP excluding construction & OECD & Jan-1985 \\
\hline
\end{tabular}

Note: * Quarterly data interpolated using quadratic-match average 


\section{Table 9. Country Sources on Purchasing Managers' Index}

\begin{tabular}{|c|c|c|c|}
\hline Country & Data Description & Source & Start Date \\
\hline United States & Manufacturing PMI & Institute for Supply Management & Jan-1948 \\
\hline United Kingdom & Manufacturing PMI & CIPS/Markit & Jan-1992 \\
\hline Austria & Manufacturing PMI & Creditanstalt & Oct-1998 \\
\hline \multicolumn{4}{|l|}{ Belgium } \\
\hline France & Manufacturing PMI & Markit/Comp des Dirigeants et Acheteurs France & Apr-1998 \\
\hline Germany & Manufacturing PMI & Markit & Apr-1996 \\
\hline Italy & Manufacturing PMI & Markit/Associazione Ital Acquisti e Supply Mgmt & Jun-1997 \\
\hline Netherlands & Manufacturing PMI & NEVI & Mar-2000 \\
\hline Sweden & Manufacturing PMI & Swedbank & Nov-1994 \\
\hline Switzerland & Manufacturing PMI & SVME/Credit Suisse/Markit & Jan-1995 \\
\hline Canada & Total Economy PMI & Richard Ivey School of Business/Univ W Ontario & Jan-2001 \\
\hline Japan & Manufacturing PMI & Markit/Japan Materials Management Association & Oct-2001 \\
\hline Greece & Manufacturing PMI & Markit & May-1999 \\
\hline \multicolumn{4}{|l|}{ Portugal } \\
\hline Spain & Manufacturing PMI & Markit & Feb-1998 \\
\hline Turkey & Manufacturing PMI & HSBC/Markit & Jun-2005 \\
\hline Australia & Manufacturing PMI* & Australian Industry Group-PricewaterhouseCoopers & Sep-1992 \\
\hline South Africa & Manufacturing PMI & Investec/IPSA/Markit & Sep-1999 \\
\hline \multicolumn{4}{|l|}{ Argentina } \\
\hline Brazil & Manufacturing PMI & HSBC/Markit & Feb-2006 \\
\hline \multicolumn{4}{|l|}{ Chile } \\
\hline \multicolumn{4}{|l|}{ Colombia } \\
\hline \multicolumn{4}{|l|}{ Costa Rica } \\
\hline Mexico & Manufacturing PMI & Instituto Nacional de Estadística Geografía e Informática & Jan-2004 \\
\hline \multicolumn{4}{|l|}{ Peru } \\
\hline \multicolumn{4}{|l|}{ Venezuela } \\
\hline Taiwan & Manufacturing PMI & HSBC/Markit & Apr-2004 \\
\hline India & Manufacturing PMI & HSBC/Markit & Mar-2005 \\
\hline \multicolumn{4}{|l|}{ Indonesia } \\
\hline South Korea & Manufacturing PMI & HSBC/Markit & Apr-2004 \\
\hline \multicolumn{4}{|l|}{ Malaysia } \\
\hline \multicolumn{4}{|l|}{ Philippines } \\
\hline \multicolumn{4}{|l|}{ Thailand } \\
\hline \multicolumn{4}{|l|}{ Nigeria } \\
\hline \multicolumn{4}{|l|}{ Bulgaria } \\
\hline Russia & Manufacturing PMI & HSBC/Markit & Sep-1997 \\
\hline China & Manufacturing PMI & HSBC/Markit & Apr-2004 \\
\hline Czech Republic & Manufacturing PMI & HSBC/Markit & Jun-2001 \\
\hline Hungary & Manufacturing PMI & Hungary Assoc Logistics, Purchasing, Inventory & Sep-1995 \\
\hline Poland & Manufacturing PMI & HSBC/Markit & Jun-1998 \\
\hline
\end{tabular}

Note: * Quarterly data interpolated using quadratic-match average from 1992 to 2001 
Table 10. Country Sources on Headline Consumer Price Index

\begin{tabular}{|c|c|c|c|}
\hline Country & Data Description & Source & Start Date \\
\hline United States & CPI & Bureau of Labor Statistics & Jan-1947 \\
\hline \multirow[t]{2}{*}{ United Kingdom } & CPI & Office for National Statistics & Jan-1988 \\
\hline & CPI & OECD & Jan-1955 \\
\hline Austria & CPI & Statistik Austria & Jan-1967 \\
\hline Belgium & CPI & $\begin{array}{l}\text { Banque Nationale de Belgique/Ministry of Economic } \\
\text { Affairs }\end{array}$ & Jan-1947 \\
\hline France & CPI & Institut Nat de la Statistique et des Etudes Economiques & Jan-1951 \\
\hline Germany & CPI & Deutsche Bundesbank & Jun-1948 \\
\hline Italy & CPI & Istituto Nazionale di Statistica & Jan-1957 \\
\hline Netherlands & CPI & Centraal Bureau voor de Statistiek & Jan-1957 \\
\hline Sweden & CPI & Statistiska Centralbyran & Jan-1955 \\
\hline Switzerland & CPI & Swiss Federal Statistical Office & Jan-1921 \\
\hline Canada & CPI & Statistics Canada & Jan-1921 \\
\hline Japan & CPI & Ministry of Internal Affairs and Communications & Jan-1970 \\
\hline Greece & CPI & Hellenic Statistical Authority (ELSTAT) & Jan-1959 \\
\hline Portugal & CPI & Instituto Nacional de Estatística & Jan-1957 \\
\hline Spain & CPI & Instituto Nacional de Estadística & Jan-1961 \\
\hline Turkey & CPI & Turkish Statistical Institute & Jan-1969 \\
\hline Australia & CPI* & Australian Bureau of Statistics & Q3-1948 \\
\hline South Africa & Urban Areas: CPI & Statistics South Africa & Jan-1960 \\
\hline Argentina & CPI & Instituto Nacional de Estadística y Censos & Jun-1984 \\
\hline Brazil & CPI & Instituto Brasileiro de Geografia e Estatística & Jan-1995 \\
\hline Chile & CPI & Instituto Nacional de Estadísticas & Jan-1958 \\
\hline Colombia & CPI & Departamento Administrativo Nacional de Estadísticas & Jan-1954 \\
\hline Costa Rica & CPI & Instituto Nacional de Estadística y Censos & Jan-1976 \\
\hline Mexico & $\mathrm{CPI}$ & $\begin{array}{l}\text { Instituto Nacional de Estadística Geografía e } \\
\text { Informática }\end{array}$ & Jan-1969 \\
\hline Peru & CPI & Instituto Nacional de Estadística e Informática & Jan-1991 \\
\hline Venezuela & CPI & Banco Central de Venezuela & Jan-1950 \\
\hline Taiwan & CPI & Directorate-General of Budget Accounting \& Stats & Jan-1959 \\
\hline \multirow[t]{2}{*}{ India } & CPI & Ministry of Statistics and Programme Implementation & Jan-2006 \\
\hline & CPI & OECD & Jan-1957 \\
\hline Indonesia & CPI & Biro Pusat Statistik & Jan-1968 \\
\hline South Korea & CPI & National Statistics Office & Jan-1955 \\
\hline Malaysia & CPI & Department of Statistics, Malaysia & Jan-1957 \\
\hline Philippines & CPI & National Statistics Office & Jan-1957 \\
\hline Thailand & CPI & Dept of Internal Trade, Ministry of Commerce & Jan-1965 \\
\hline Nigeria & CPI & National Bureau of Statistics, Nigeria & Apr-1962 \\
\hline Bulgaria & CPI & National Statistical Institute & May-1990 \\
\hline Russia & CPI & Federal State Statistics Service & Jan-1991 \\
\hline China & CPI & China National Bureau of Statistics & Jan-1984 \\
\hline
\end{tabular}




\begin{tabular}{llll} 
Country & Data Description & Source & Start Date \\
\hline Czech Republic & CPI & Czech Statistical Office & Jan-1991 \\
Hungary & CPI & Central Statistical Office & Jan-1976 \\
Poland & CPI & Central Statistical Office, Poland & Jan-1988
\end{tabular}

Note: * Quarterly data interpolated using quadratic-match average 


\section{Table 11. Country Sources on Core Consumer Price Index}

\begin{tabular}{|c|c|c|c|}
\hline Country & Data Description & Source & Start Date \\
\hline United States & CPI: All items less food and energy & Bureau of Labor Statistics & Jan-1957 \\
\hline \multirow[t]{2}{*}{ United Kingdom } & $\begin{array}{l}\text { HICP: Total excluding energy and } \\
\text { unprocessed food }\end{array}$ & $\begin{array}{l}\text { Statistical Office of the European } \\
\text { Communities }\end{array}$ & Jan-1996 \\
\hline & CPI: All items excluding food and energy & OECD & Jan-1970 \\
\hline \multirow[t]{2}{*}{ Austria } & $\begin{array}{l}\text { HICP: Total excluding energy and } \\
\text { unprocessed food }\end{array}$ & $\begin{array}{l}\text { Statistical Office of the European } \\
\text { Communities }\end{array}$ & Jan-1990 \\
\hline & CPI: All items excluding food and energy & OECD & Jan-1966 \\
\hline \multirow[t]{2}{*}{ Belgium } & $\begin{array}{l}\text { HICP: Total excluding energy and } \\
\text { unprocessed food }\end{array}$ & $\begin{array}{l}\text { Statistical Office of the European } \\
\text { Communities }\end{array}$ & Jan-1991 \\
\hline & CPI: All items excluding food and energy & OECD & Jun-1976 \\
\hline \multirow[t]{2}{*}{ France } & $\begin{array}{l}\text { HICP: Total excluding energy and } \\
\text { unprocessed food }\end{array}$ & $\begin{array}{l}\text { Statistical Office of the European } \\
\text { Communities }\end{array}$ & Jan-1990 \\
\hline & CPI: All items excluding food and energy & OECD & Jan-1960 \\
\hline \multirow[t]{2}{*}{ Germany } & $\begin{array}{l}\text { HICP: Total excluding energy and } \\
\text { unprocessed food }\end{array}$ & $\begin{array}{l}\text { Statistical Office of the European } \\
\text { Communities }\end{array}$ & Jan-1995 \\
\hline & CPI: All items excluding food and energy & OECD & Jan-1962 \\
\hline \multirow[t]{2}{*}{ Italy } & $\begin{array}{l}\text { HICP: Total excluding energy and } \\
\text { unprocessed food }\end{array}$ & $\begin{array}{l}\text { Statistical Office of the European } \\
\text { Communities }\end{array}$ & Jan-1990 \\
\hline & CPI less food and energy & OECD & Jan-1960 \\
\hline \multirow[t]{2}{*}{ Netherlands } & $\begin{array}{l}\text { HICP: Total excluding energy and } \\
\text { unprocessed food }\end{array}$ & $\begin{array}{l}\text { Statistical Office of the European } \\
\text { Communities }\end{array}$ & Jan-1990 \\
\hline & CPI: All items excluding food and energy & OECD & Apr-1960 \\
\hline \multirow[t]{2}{*}{ Sweden } & $\begin{array}{l}\text { HICP: Total excluding energy and } \\
\text { unprocessed food }\end{array}$ & $\begin{array}{l}\text { Statistical Office of the European } \\
\text { Communities }\end{array}$ & Jan-1990 \\
\hline & CPI: All items excluding food and energy & OECD & Jan-1970 \\
\hline \multirow[t]{2}{*}{ Switzerland } & $\begin{array}{l}\text { CPI excluding food, bev, tobacco, } \\
\text { seasonal prods, and energy }\end{array}$ & Swiss Federal Statistical Office & May-1993 \\
\hline & CPI: All items excluding food and energy & OECD & Jan-1955 \\
\hline \multirow[t]{2}{*}{ Canada } & CPI: All items less food and energy & Statistics Canada & Jan-1992 \\
\hline & CPI: All items excluding food and energy & OECD & Jan-1961 \\
\hline Japan & CPI: All items excluding food and energy & $\begin{array}{l}\text { Ministry of Internal Affairs and } \\
\text { Communications }\end{array}$ & Jan-1970 \\
\hline \multirow[t]{2}{*}{ Greece } & $\begin{array}{l}\text { HICP: Total excluding energy and } \\
\text { unprocessed food }\end{array}$ & $\begin{array}{l}\text { Statistical Office of the European } \\
\text { Communities }\end{array}$ & Jan-1996 \\
\hline & CPI: All items less food and energy & OECD & Jan-1989 \\
\hline Portugal & $\begin{array}{l}\text { HICP: Total excluding energy and } \\
\text { unprocessed food }\end{array}$ & $\begin{array}{l}\text { Statistical Office of the European } \\
\text { Communities }\end{array}$ & Jan-1990 \\
\hline \multirow[t]{2}{*}{ Spain } & $\begin{array}{l}\text { CPI excluding nonprocessed foods and } \\
\text { energy products }\end{array}$ & Instituto Nacional de Estadística & Aug-1985 \\
\hline & CPI: All items excluding food and energy & OECD & Jan-1976 \\
\hline Turkey & CPI: All items less food less energy & OECD & Jan-1994 \\
\hline \multirow[t]{2}{*}{ Australia } & CPI: All groups excluding volatile items* & Australian Bureau of Statistics & Q3-1948 \\
\hline & $\begin{array}{l}\text { CPI: All items excluding food and } \\
\text { energy* }\end{array}$ & OECD & Q3-1976 \\
\hline South Africa & $\begin{array}{l}\text { Urban Areas: CPI excluding food, NAB, } \\
\text { petrol, and energy }\end{array}$ & Statistics South Africa & Jan-2002 \\
\hline
\end{tabular}




\begin{tabular}{|c|c|c|c|}
\hline Country & Data Description & Source & Start Date \\
\hline \multirow[t]{2}{*}{ Argentina } & $\begin{array}{l}\text { CPI: Nonseasonal/not price controlled } \\
\text { goods and services }\end{array}$ & $\begin{array}{l}\text { Instituto Nacional de Estadística y } \\
\text { Censos }\end{array}$ & Dec-2002 \\
\hline & CPI excluding food and energy^ & BIS & Q1-1993 \\
\hline Brazil & Brazil: National core CPI & $\begin{array}{l}\text { Instituto Brasileiro de Geografia e } \\
\text { Estatística }\end{array}$ & Dec-1995 \\
\hline Chile & Chile: CPI less food and energy & Instituto Nacional de Estadísticas & Jan-1979 \\
\hline Colombia & CPI less perishables, fuel, and utilities & Banco de la República & Dec-1998 \\
\hline Costa Rica & CPI: Core & $\begin{array}{l}\text { Instituto Nacional de Estadística y } \\
\text { Censos }\end{array}$ & Jan-1995 \\
\hline Mexico & CPI: Core & $\begin{array}{l}\text { Instituto Nacional de Estadística } \\
\text { Geografía e Informática }\end{array}$ & Jan-1982 \\
\hline Peru & CPI: Core & $\begin{array}{l}\text { Instituto Nacional de Estadística e } \\
\text { Informática }\end{array}$ & Dec-1990 \\
\hline Venezuela & CPI: Core (metro) & Banco Central de Venezuela & Jan-1999 \\
\hline Taiwan & $\begin{array}{l}\text { CPI: General index excluding food and } \\
\text { energy }\end{array}$ & $\begin{array}{l}\text { Directorate-General of Budget } \\
\text { Accounting \& Stats }\end{array}$ & Jan-1981 \\
\hline \multirow[t]{2}{*}{ India } & CPI excluding food and energy & $\begin{array}{l}\text { Ministry of Statistics and Programme } \\
\text { Implementation }\end{array}$ & Jan-2011 \\
\hline & CPI excluding food and energy & Labour Bureau of India & Jan-2006 \\
\hline Indonesia & CPI: Excluding food products & Biro Pusat Statistik & Dec-2007 \\
\hline South Korea & $\begin{array}{l}\text { CPI: All items excluding agricultural } \\
\text { products and oil }\end{array}$ & National Statistics Office & Jan-1975 \\
\hline Malaysia & CPI excluding food and energy & Department of Statistics, Malaysia & Jan-2005 \\
\hline Philippines & Core CPI excluding food and energy & National Statistics Office & Jun-2003 \\
\hline Thailand & CPI excluding food and energy & $\begin{array}{l}\text { Dept of Internal Trade, Ministry of } \\
\text { Commerce }\end{array}$ & Jan-1990 \\
\hline Nigeria & $\begin{array}{l}\text { CPI: All items less farm produce and } \\
\text { energy }\end{array}$ & National Bureau of Statistics, Nigeria & Jan-2003 \\
\hline Bulgaria & $\begin{array}{l}\text { HICP: Total excluding energy and } \\
\text { unprocessed food }\end{array}$ & $\begin{array}{l}\text { Statistical Office of the European } \\
\text { Communities }\end{array}$ & Dec-1996 \\
\hline Russia & CPI: All items less food & OECD & Jan-1992 \\
\hline China & CPI excluding food and energy & China National Bureau of Statistics & Jan-2005 \\
\hline Czech Republic & Core CPI & Czech Statistical Office & Jan-1998 \\
\hline Hungary & Core CPI & Central Statistical Office & Jan-1995 \\
\hline Poland & $\begin{array}{l}\text { HICP: Total excluding energy and } \\
\text { unprocessed food }\end{array}$ & $\begin{array}{l}\text { Statistical Office of the European } \\
\text { Communities }\end{array}$ & Jan-1996 \\
\hline
\end{tabular}

Notes: * Quarterly data interpolated using quadratic-match average. ^ Quarterly data interpolated using log linear interpolation. 
Table 12. Country Sources on Producer Price Index/Wholesale Price Index

\begin{tabular}{|c|c|c|c|}
\hline Country & Data Description & Source & Start Date \\
\hline United States & PPI: Finished goods & Bureau of Labor Statistics & Apr-1947 \\
\hline $\begin{array}{l}\text { United } \\
\text { Kingdom }\end{array}$ & PPI: Manufactured products & Office for National Statistics & Jan-1974 \\
\hline Austria & $\begin{array}{l}\text { PPI: Industry excluding } \\
\text { construction }\end{array}$ & Statistical Office of the European Communities & Jan-1996 \\
\hline Belgium & PPI: Output prices & $\begin{array}{l}\text { Banque Nationale de Belgique/Ministry of } \\
\text { Economic Affairs }\end{array}$ & Jan-1980 \\
\hline \multirow[t]{2}{*}{ France } & $\begin{array}{l}\text { PPI: Industry excluding } \\
\text { construction }\end{array}$ & $\begin{array}{l}\text { Institut Nat de la Statistique et des Etudes } \\
\text { Economiques }\end{array}$ & Jan-1999 \\
\hline & $\begin{array}{l}\text { PPI: Industry excluding } \\
\text { construction }\end{array}$ & Statistical Office of the European Communities & Jan-1995 \\
\hline Germany & $\begin{array}{l}\text { PPI: Total industry excluding } \\
\text { construction }\end{array}$ & Deutsche Bundesbank & Jan-1949 \\
\hline Italy & PPI & Istituto Nazionale di Statistica & Jan-1981 \\
\hline Netherlands & PPI: Manufacturing & Centraal Bureau voor de Statistiek & Jan-1981 \\
\hline Sweden & PPI & Statistiska Centralbyran & Jan-1975 \\
\hline Switzerland & PPI & Swiss Federal Statistical Office & Jan-1926 \\
\hline Canada & PPI: All commodities & Statistics Canada & Jan-1956 \\
\hline Japan & PPI: Manufacturing & Bank of Japan & Jan-1975 \\
\hline Greece & PPI: Total industry & Hellenic Statistical Authority (ELSTAT) & Jan-1995 \\
\hline Portugal & $\begin{array}{l}\text { PPI: Industry excluding } \\
\text { construction }\end{array}$ & Statistical Office of the European Communities & Jan-1990 \\
\hline Spain & PPI: Total industry & Instituto Nacional de Estadística & Jan-1975 \\
\hline Turkey & PPI: General & Turkish Statistical Institute & Jan-1986 \\
\hline Australia & PPI by stage of processing: Final* & Australian Bureau of Statistics & Q3-1998 \\
\hline \multirow[t]{2}{*}{ South Africa } & PPI: Manufacturing & Statistics South Africa & Jan-2012 \\
\hline & PPI: Industry output & Statistics South Africa & Jan-1970 \\
\hline Argentina & PPI & Instituto Nacional de Estadística y Censos & Jan-1993 \\
\hline Brazil & WPI: Domestic Supply & Fundaçâo Getúlio Vargas & Aug-1991 \\
\hline Chile & PPI & Instituto Nacional de Estadísticas & Apr-2003 \\
\hline Colombia & PPI & $\begin{array}{l}\text { Departamento Administrativo Nacional de } \\
\text { Estadísticas }\end{array}$ & Jan-1970 \\
\hline Costa Rica & PPI & Banco Central de Costa Rica & Jan-1991 \\
\hline Mexico & $\begin{array}{l}\text { PPI: Total production excluding } \\
\text { oil }\end{array}$ & $\begin{array}{l}\text { Instituto Nacional de Estadística Geografía e } \\
\text { Informática }\end{array}$ & Dec-2003 \\
\hline Peru & WPI & Instituto Nacional de Estadística e Informática & Jan-1986 \\
\hline Venezuela & PPI: Private manufacturing & Banco Central de Venezuela & Jan-1998 \\
\hline Taiwan & WPI & $\begin{array}{l}\text { Directorate-General of Budget Accounting \& } \\
\text { Stats }\end{array}$ & Jan-1952 \\
\hline India & WPI: All Items & Ministry of Commerce and Industry & Jan-1957 \\
\hline Indonesia & WPI & Biro Pusat Statistik & Jan-1971 \\
\hline South Korea & PPI: All items & National Statistics Office & Jan-1965 \\
\hline Malaysia & PPI: Domestic economy & Department of Statistics, Malaysia & Feb-1986 \\
\hline \multirow[t]{2}{*}{ Philippines } & PPI: Total manufacturing & National Statistics Office & Jan-2000 \\
\hline & WPI: All items & National Statistics Office & Jan-1983 \\
\hline
\end{tabular}




\begin{tabular}{llll} 
Country & Data Description & Source & Start Date \\
\hline $\begin{array}{l}\text { Thailand } \\
\text { Nigeria }\end{array}$ & PPI & Dept of Internal Trade, Ministry of Commerce & Jan-1995 \\
Bulgaria & PPI & National Statistical Institute & \\
Russia & PPI: Total & Federal State Statistics Service & Jan-2004 \\
China & PPI: All industry products & China National Bureau of Statistics & Feb-1992 \\
Czech & PPI: Manufacturing & Czech Statistical Office & Jan-1996 \\
Republic & & & Feb-1991 \\
Hungary & PPI: Total industry & Central Statistical Office & Jan-1986 \\
Poland & PPI & Central Statistical Office, Poland & Jun-1985
\end{tabular}

Note: * Quarterly data interpolated using quadratic-match average 
Table 13. Country Sources on Merchandise Imports

\begin{tabular}{|c|c|c|c|}
\hline Country & Data Description & Source & Start Date \\
\hline United States & Imports of goods (customs value) in U.S.\$ & Bureau of the Census & Jan-1948 \\
\hline United Kingdom & Imports of goods in U.S.\$ & $\begin{array}{l}\text { Office for National } \\
\text { Statistics }\end{array}$ & Jan-1980 \\
\hline Austria & Merchandise imports in U.S.\$ & Statistik Austria & Jan-1970 \\
\hline \multirow[t]{2}{*}{ Belgium } & Imports in U.S.\$ & $\begin{array}{l}\text { Banque Nationale de } \\
\text { Belgique }\end{array}$ & Jan-1993 \\
\hline & $\begin{array}{l}\text { Imports calculated using share of Bel-Lux } \\
\text { imports }\end{array}$ & IMF & Jan-1980 \\
\hline \multirow[t]{2}{*}{ France } & Imports of goods in U.S.\$ & $\begin{array}{l}\text { Dir Génl des Douanes et des } \\
\text { Droits Indirects }\end{array}$ & Jan-1988 \\
\hline & Merchandise imports (cif) from world in U.S.\$ & IMF & Jan-1980 \\
\hline Germany & Imports of goods in U.S.\$ & Deutsche Bundesbank & Jan-1951 \\
\hline \multirow[t]{2}{*}{ Italy } & Imports of goods in U.S.\$ & $\begin{array}{l}\text { Istituto Nazionale di } \\
\text { Statistica }\end{array}$ & Jan-1993 \\
\hline & Merchandise imports (cif) from world in U.S.\$ & IMF & Jan-1980 \\
\hline \multirow[t]{2}{*}{ Netherlands } & Imports of goods in U.S.\$ & $\begin{array}{l}\text { Centraal Bureau voor de } \\
\text { Statistiek }\end{array}$ & Jan-1996 \\
\hline & Merchandise imports (cif) from world in U.S.\$ & IMF & Jan-1980 \\
\hline Sweden & Imports of goods in U.S.\$ & Statistiska Centralbyran & Jan-1975 \\
\hline Switzerland & $\begin{array}{l}\text { Imports of goods excluding precious metals in } \\
\text { U.S.\$ } \\
\text { Merchandise imports (cif) from world in U.S.\$ }\end{array}$ & $\begin{array}{l}\text { Directorate General of } \\
\text { Customs } \\
\text { IMF }\end{array}$ & $\begin{array}{l}\text { Jan-1988 } \\
\text { Jan-1980 }\end{array}$ \\
\hline \multirow[t]{2}{*}{ Canada } & Imports of goods in U.S.\$ & Statistics Canada & Jan-1988 \\
\hline & Merchandise imports (cif) from world in U.S.\$ & IMF & Jan-1980 \\
\hline Japan & Imports of goods in U.S.\$ & $\begin{array}{l}\text { Ministry of Finance/Japan } \\
\text { Tariff Association }\end{array}$ & Jan-1969 \\
\hline Greece & $\begin{array}{l}\text { Imports of goods including oil products SUSP } \\
\text { in U.S.\$ } \\
\text { Merchandise imports (cif) from world in U.S.\$ }\end{array}$ & $\begin{array}{l}\text { Hellenic Statistical } \\
\text { Authority (ELSTAT) } \\
\text { IMF }\end{array}$ & $\begin{array}{l}\text { Jun-2001 } \\
\text { Jan-1980 }\end{array}$ \\
\hline \multirow[t]{2}{*}{ Portugal } & Imports of goods in U.S.\$ & $\begin{array}{l}\text { Instituto Nacional de } \\
\text { Estatística }\end{array}$ & Jan-1993 \\
\hline & Merchandise imports (cif) from world in U.S.\$ & IMF & Jan-1980 \\
\hline Spain & Imports of goods in U.S.\$ & Banco de España & Jan-1970 \\
\hline \multirow[t]{2}{*}{ Turkey } & Total merchandise imports (cif) in U.S.\$ & Turkish Statistical Institute & Jan-1997 \\
\hline & Merchandise imports (cif) from world in U.S.\$ & IMF & Jan-1980 \\
\hline \multirow[t]{2}{*}{ Australia } & Imports in U.S.\$ & $\begin{array}{l}\text { Australian Bureau of } \\
\text { Statistics }\end{array}$ & Jan-1988 \\
\hline & Merchandise imports (cif) from world in U.S.\$ & IMF & Jan-1980 \\
\hline \multirow[t]{3}{*}{ South Africa } & Goods imports in U.S.\$ & $\begin{array}{l}\text { South African Revenue } \\
\text { Service }\end{array}$ & Jan-2010 \\
\hline & Merchandise imports (cif) from world in U.S.\$ & IMF & Jan-1998 \\
\hline & $\begin{array}{l}\text { Imports pre-1998 calculated using share of } \\
\text { SACU imports }\end{array}$ & IMF & Jan-1980 \\
\hline \multirow[t]{2}{*}{ Argentina } & Goods imports in U.S.\$ & $\begin{array}{l}\text { Instituto Nacional de } \\
\text { Estadística y Censos }\end{array}$ & Jan-1990 \\
\hline & Merchandise imports (cif) from world in U.S.\$ & IMF & Jan-1980 \\
\hline Brazil & Merchandise imports in U.S.\$ & Banco Central do Brasil & Jan-1959 \\
\hline
\end{tabular}




\begin{tabular}{|c|c|c|c|}
\hline Country & Data Description & Source & Start Date \\
\hline \multirow[t]{2}{*}{ Chile } & Merchandise imports (cif) in U.S.\$ & Banco Central de Chile & Jan-2003 \\
\hline & Merchandise imports (cif) from world in U.S.\$ & IMF & Jan-1980 \\
\hline Colombia & Imports of goods (cif) in U.S.\$ & $\begin{array}{l}\text { Departamento } \\
\text { Administrativo Nacional de } \\
\text { Estadísticas }\end{array}$ & Jan-1957 \\
\hline \multirow[t]{2}{*}{ Costa Rica } & Imports (cif) in U.S.\$ & $\begin{array}{l}\text { Banco Central de Costa } \\
\text { Rica }\end{array}$ & Jan-1994 \\
\hline & Merchandise imports (cif) from world in U.S.\$ & IMF & Jan-1980 \\
\hline Mexico & Imports (fob) in U.S.\$ & $\begin{array}{l}\text { Instituto Nacional de } \\
\text { Estadística y Geografía }\end{array}$ & Jan-1980 \\
\hline Peru & Merchandise imports (fob) in U.S.\$ & $\begin{array}{l}\text { Banco Central de Reserva } \\
\text { del Perú }\end{array}$ & Jan-1980 \\
\hline \multirow[t]{2}{*}{ Venezuela } & Merchandise imports in U.S.\$ & $\begin{array}{l}\text { Instituto Nacional de } \\
\text { Estadística Venezuela }\end{array}$ & Jan-1992 \\
\hline & $\begin{array}{l}\text { Merchandise imports (cif) from world in } \\
\text { U.S.\$* }\end{array}$ & IMF & Jan-1980 \\
\hline Taiwan & Merchandise imports in U.S.\$ & Ministry of Finance, R.O.C. & Jan-1978 \\
\hline India & Merchandise imports in U.S.\$ & $\begin{array}{l}\text { Ministry of Commerce and } \\
\text { Industry }\end{array}$ & Jan-1968 \\
\hline \multirow[t]{2}{*}{ Indonesia } & Merchandise imports in U.S.\$ & Biro Pusat Statistik & Aug-1980 \\
\hline & Merchandise imports (cif) from world in U.S.\$ & IMF & Jan-1980 \\
\hline South Korea & Merchandise imports in U.S.\$ & Korea Customs Service & Jan-1967 \\
\hline Malaysia & Merchandise imports (fob) in U.S.\$ & $\begin{array}{l}\text { Department of Statistics, } \\
\text { Malaysia }\end{array}$ & Jul-1972 \\
\hline \multirow[t]{2}{*}{ Philippines } & Merchandise imports (fob) in U.S.\$ & National Statistics Office & Apr-1983 \\
\hline & Merchandise imports (cif) from world in U.S.\$ & IMF & Jan-1980 \\
\hline \multirow[t]{2}{*}{ Thailand } & Merchandise imports (cif) in U.S.\$ & Ministry of Commerce & Jan-1991 \\
\hline & Merchandise imports (cif) from world in U.S.\$ & IMF & Jan-1980 \\
\hline \multirow[t]{2}{*}{ Nigeria } & Imports (cif) in U.S.\$ & $\begin{array}{l}\text { National Bureau of } \\
\text { Statistics, Nigeria }\end{array}$ & Jan-2008 \\
\hline & $\begin{array}{l}\text { Merchandise imports (cif) from world in } \\
\text { U.S.\$* }\end{array}$ & IMF & Jan-1980 \\
\hline \multirow[t]{2}{*}{ Bulgaria } & Merchandise imports (fob) in U.S.\$ & National Statistical Institute & Jan-1995 \\
\hline & Merchandise imports (cif) from world in U.S.\$ & IMF & Jan-1981 \\
\hline \multirow[t]{2}{*}{ Russia } & Imports of goods (fob) in U.S.\$ & $\begin{array}{l}\text { Central Bank of the Russian } \\
\text { Federation }\end{array}$ & Jan-1994 \\
\hline & Merchandise imports (cif) from world in U.S.\$ & IMF & Jan-1992 \\
\hline \multirow[t]{2}{*}{ China } & Merchandise imports (cif) in U.S.\$ & China Customs & Oct-1983 \\
\hline & Merchandise imports (cif) from world in U.S.\$ & IMF & Jan-1981 \\
\hline Czech Republic & Merchandise imports (fob) in U.S.\$ & Czech Statistical Office & Mar-1992 \\
\hline \multirow[t]{2}{*}{ Hungary } & Merchandise imports (cif) in U.S.\$ & Central Statistical Office & Jan-1990 \\
\hline & $\begin{array}{l}\text { Merchandise imports (cif) from world in } \\
\text { U.S.\$* }\end{array}$ & IMF & Jan-1980 \\
\hline \multirow[t]{2}{*}{ Poland } & Total imports (cif) in U.S.\$ & $\begin{array}{l}\text { Central Statistical Office, } \\
\text { Poland }\end{array}$ & Jan-1986 \\
\hline & Merchandise imports (cif) from world in U.S.\$ & IMF & Jan-1981 \\
\hline
\end{tabular}


Table 14. Country Sources on Merchandise Exports

\begin{tabular}{|c|c|c|c|}
\hline Country & Data Description & Source & Start Date \\
\hline United States & Exports of goods (f.a.s.) in U.S.\$ & Bureau of the Census & Jan-1948 \\
\hline \multirow[t]{2}{*}{ United Kingdom } & Exports of goods in U.S.\$ & $\begin{array}{l}\text { Office for National } \\
\text { Statistics }\end{array}$ & Jan-1998 \\
\hline & Merchandise exports to world in U.S.\$ & IMF & Jan-1980 \\
\hline Austria & Merchandise exports in U.S.\$ & Statistik Austria & Jan-1970 \\
\hline \multirow[t]{2}{*}{ Belgium } & Exports in U.S.\$ & $\begin{array}{l}\text { Banque Nationale de } \\
\text { Belgique }\end{array}$ & Jan-1993 \\
\hline & $\begin{array}{l}\text { Exports calculated using share of Bel-Lux } \\
\text { exports }\end{array}$ & IMF & Jan-1980 \\
\hline \multirow[t]{2}{*}{ France } & Exports of goods in U.S.\$ & $\begin{array}{l}\text { Dir Génl des Douanes et des } \\
\text { Droits Indirects }\end{array}$ & Jan-1988 \\
\hline & Merchandise exports to world in U.S.\$ & IMF & Jan-1980 \\
\hline Germany & Exports of goods in U.S.\$ & Deutsche Bundesbank & Jan-1951 \\
\hline \multirow[t]{2}{*}{ Italy } & Exports of goods in U.S.\$ & $\begin{array}{l}\text { Istituto Nazionale di } \\
\text { Statistica }\end{array}$ & Jan-1993 \\
\hline & Merchandise exports to world in U.S.\$ & IMF & Jan-1980 \\
\hline \multirow[t]{2}{*}{ Netherlands } & Exports of goods in U.S.\$ & $\begin{array}{l}\text { Centraal Bureau voor de } \\
\text { Statistiek }\end{array}$ & Jan-1996 \\
\hline & Merchandise exports to world in U.S.\$ & IMF & Jan-1980 \\
\hline Sweden & Exports of goods in U.S.\$ & Statistiska Centralbyran & Jan-1975 \\
\hline Switzerland & $\begin{array}{l}\text { Exports of goods excluding precious metals in } \\
\text { U.S.\$ } \\
\text { Merchandise exports to world in U.S.\$ }\end{array}$ & $\begin{array}{l}\text { Directorate General of } \\
\text { Customs } \\
\text { IMF }\end{array}$ & $\begin{array}{l}\text { Jan-1988 } \\
\text { Jan-1980 }\end{array}$ \\
\hline \multirow[t]{2}{*}{ Canada } & Exports of goods in U.S.\$ & Statistics Canada & Jan-1988 \\
\hline & Merchandise exports to world in U.S.\$ & IMF & Jan-1980 \\
\hline Japan & Exports of goods in U.S.\$ & $\begin{array}{l}\text { Ministry of Finance/Japan } \\
\text { Tariff Association }\end{array}$ & Jan-1957 \\
\hline Greece & $\begin{array}{l}\text { Exports of goods including oil products SUSP } \\
\text { in U.S.\$ } \\
\text { Merchandise exports to world in U.S.\$ }\end{array}$ & $\begin{array}{l}\text { Hellenic Statistical } \\
\text { Authority (ELSTAT) } \\
\text { IMF }\end{array}$ & $\begin{array}{l}\text { Jun-2001 } \\
\text { Jan-1980 }\end{array}$ \\
\hline \multirow[t]{2}{*}{ Portugal } & Exports of goods in U.S.\$ & $\begin{array}{l}\text { Instituto Nacional de } \\
\text { Estatística }\end{array}$ & Jan-1993 \\
\hline & Merchandise exports to world in U.S.\$ & IMF & Jan-1980 \\
\hline Spain & Exports of goods in U.S.\$ & Banco de España & Jan-1970 \\
\hline \multirow[t]{2}{*}{ Turkey } & Total merchandise exports (fob) in U.S.\$ & Turkish Statistical Institute & Jan-1997 \\
\hline & Merchandise exports to world in U.S.\$ & IMF & Jan-1980 \\
\hline \multirow[t]{2}{*}{ Australia } & Exports in U.S.\$ & $\begin{array}{l}\text { Australian Bureau of } \\
\text { Statistics }\end{array}$ & Jan-1988 \\
\hline & Merchandise exports to world in U.S.\$ & IMF & Jan-1980 \\
\hline \multirow[t]{3}{*}{ South Africa } & Goods exports in U.S.\$ & $\begin{array}{l}\text { South African Revenue } \\
\text { Service }\end{array}$ & Jan-2010 \\
\hline & Merchandise exports to world in U.S.\$ & IMF & Jan-1998 \\
\hline & $\begin{array}{l}\text { Exports pre-1998 calculated using share of } \\
\text { SACU exports }\end{array}$ & IMF & Jan-1980 \\
\hline \multirow[t]{2}{*}{ Argentina } & Goods exports in U.S.\$ & $\begin{array}{l}\text { Instituto Nacional de } \\
\text { Estadística y Censos }\end{array}$ & Jan-1990 \\
\hline & Merchandise exports to world in U.S.\$ & IMF & Jan-1980 \\
\hline
\end{tabular}




\begin{tabular}{|c|c|c|c|}
\hline Country & Data Description & Source & Start Date \\
\hline Brazil & Merchandise exports in U.S.\$ & Banco Central do Brasil & Jan-1954 \\
\hline \multirow[t]{2}{*}{ Chile } & Merchandise exports (fob) in U.S.\$ & Banco Central de Chile & Jan-1987 \\
\hline & Merchandise exports to world in U.S.\$ & IMF & Jan-1980 \\
\hline Colombia & Exports of goods (fob) in U.S.\$ & $\begin{array}{l}\text { Departamento } \\
\text { Administrativo Nacional de } \\
\text { Estadísticas }\end{array}$ & Jan-1958 \\
\hline \multirow[t]{2}{*}{ Costa Rica } & Exports (fob) in U.S.\$ & $\begin{array}{l}\text { Banco Central de Costa } \\
\text { Rica }\end{array}$ & Jan-1994 \\
\hline & Merchandise exports to world in U.S.\$ & IMF & Jan-1980 \\
\hline Mexico & Exports (fob) in U.S.\$ & $\begin{array}{l}\text { Instituto Nacional de } \\
\text { Estadística y Geografía }\end{array}$ & Jan-1980 \\
\hline Peru & Merchandise exports (fob) in U.S.\$ & $\begin{array}{l}\text { Banco Central de Reserva } \\
\text { del Perú }\end{array}$ & Jan-1980 \\
\hline \multirow[t]{2}{*}{ Venezuela } & Merchandise exports in U.S.\$ & $\begin{array}{l}\text { Instituto Nacional de } \\
\text { Estadística Venezuela }\end{array}$ & Jan-1992 \\
\hline & Merchandise exports to world in U.S.\$* & IMF & Jan-1980 \\
\hline Taiwan & Merchandise exports in U.S.\$ & Ministry of Finance, R.O.C. & Jan-1978 \\
\hline India & Merchandise exports in U.S.\$ & $\begin{array}{l}\text { Ministry of Commerce and } \\
\text { Industry }\end{array}$ & Jan-1968 \\
\hline Indonesia & Merchandise exports in U.S.\$ & Biro Pusat Statistik & Jul-1979 \\
\hline South Korea & Merchandise exports in U.S.\$ & Korea Customs Service & Jan-1967 \\
\hline Malaysia & Merchandise exports (fob) in U.S.\$ & $\begin{array}{l}\text { Department of Statistics, } \\
\text { Malaysia }\end{array}$ & Jul-1972 \\
\hline \multirow[t]{2}{*}{ Philippines } & Merchandise exports (fob) in U.S.\$ & National Statistics Office & Apr-1983 \\
\hline & Merchandise exports to world in U.S.\$ & IMF & Jan-1980 \\
\hline \multirow[t]{2}{*}{ Thailand } & Merchandise exports (fob) in U.S.\$ & Ministry of Commerce & Jan-1991 \\
\hline & Merchandise exports to world in U.S.\$ & IMF & Jan-1980 \\
\hline \multirow[t]{2}{*}{ Nigeria } & Exports (fob) in U.S.\$ & $\begin{array}{l}\text { National Bureau of } \\
\text { Statistics, Nigeria }\end{array}$ & Jan-2008 \\
\hline & Merchandise exports to world in U.S.\$* & IMF & Jan-1980 \\
\hline \multirow[t]{2}{*}{ Bulgaria } & Merchandise exports (fob) in U.S.\$ & National Statistical Institute & Jan-1995 \\
\hline & Merchandise exports to world in U.S.\$ & IMF & Jan-1981 \\
\hline \multirow[t]{2}{*}{ Russia } & Exports of goods (fob) in U.S.\$ & $\begin{array}{l}\text { Central Bank of the Russian } \\
\text { Federation }\end{array}$ & Jan-1994 \\
\hline & Merchandise exports to world in U.S.\$ & IMF & Jan-1992 \\
\hline \multirow[t]{2}{*}{ China } & Merchandise exports (fob) in U.S.\$ & China Customs & Oct-1983 \\
\hline & Merchandise exports to world in U.S.\$ & IMF & Jan-1981 \\
\hline Czech Republic & Merchandise exports (fob) in U.S.\$ & Czech Statistical Office & Mar-1992 \\
\hline \multirow[t]{2}{*}{ Hungary } & Merchandise exports (fob) in U.S.\$ & Central Statistical Office & Jan-1990 \\
\hline & Merchandise exports to world in U.S.\$ & IMF & Jan-1980 \\
\hline \multirow[t]{2}{*}{ Poland } & Total exports (fob) in U.S.\$ & $\begin{array}{l}\text { Central Statistical Office, } \\
\text { Poland }\end{array}$ & Jan-1986 \\
\hline & Merchandise exports to world in U.S.\$ & IMF & Jan-1981 \\
\hline
\end{tabular}


Table 15. Country Sources on Nominal Exchange Rates

\begin{tabular}{|c|c|c|c|}
\hline Country & Data Description & Source & Start Date \\
\hline \multicolumn{4}{|l|}{ United States } \\
\hline United Kingdom & US\$/pound (average) & Federal Reserve Board & Jan-1947 \\
\hline \multirow[t]{2}{*}{ Austria } & US\$/euro (average) & Federal Reserve Board & Jan-1999 \\
\hline & US\$/schilling (average) & Federal Reserve Board & Jan-1957 \\
\hline \multirow[t]{2}{*}{ Belgium } & US\$/euro (average) & Federal Reserve Board & Jan-1999 \\
\hline & US\$/franc (average) & Federal Reserve Board & Jan-1947 \\
\hline \multirow[t]{2}{*}{ France } & US\$/euro (average) & Federal Reserve Board & Jan-1999 \\
\hline & US\$/franc (average) & Federal Reserve Board & Jan-1957 \\
\hline \multirow[t]{2}{*}{ Germany } & US\$/euro (average) & Federal Reserve Board & Jan-1999 \\
\hline & US\$/Deutsche Mark (average) & Federal Reserve Board & Jan-1957 \\
\hline \multirow[t]{2}{*}{ Italy } & US\$/euro (average) & Federal Reserve Board & Jan-1999 \\
\hline & US\$/lira (average) & Federal Reserve Board & Jan-1957 \\
\hline \multirow[t]{2}{*}{ Netherlands } & US\$/euro (average) & Federal Reserve Board & Jan-1999 \\
\hline & US\$/guilder (average) & Federal Reserve Board & Jan-1957 \\
\hline Sweden & US\$/krona (average) & Wall Street Journal & Jan-1957 \\
\hline Switzerland & US\$/franc (average) & Wall Street Journal & Jan-1957 \\
\hline Canada & US\$/Canadian\$ (average) & Wall Street Journal & Jan-1957 \\
\hline Japan & US\$/yen (average) & Wall Street Journal & Jan-1957 \\
\hline \multirow[t]{2}{*}{ Greece } & US\$/euro (average)* & Federal Reserve Board & Jan-1999 \\
\hline & US\$/drachma (average) & Federal Reserve Board & Jan-1957 \\
\hline \multirow[t]{2}{*}{ Portugal } & US\$/euro (average) & Federal Reserve Board & Jan-1999 \\
\hline & US\$/escudo (average) & Federal Reserve Board & Jan-1957 \\
\hline \multirow[t]{2}{*}{ Spain } & US\$/euro (average) & Federal Reserve Board & Jan-1999 \\
\hline & US\$/peseta (average) & Federal Reserve Board & Jan-1957 \\
\hline Turkey & US\$/lira (average) & Wall Street Journal & Dec-1994 \\
\hline Australia & US\$/Australian\$ (average) & Wall Street Journal & Jan-1957 \\
\hline South Africa & US\$/rand (average) & Wall Street Journal & Jan-1957 \\
\hline Argentina & US\$/peso (average) & Banco Central de la República Argentina & Apr-1991 \\
\hline \multirow[t]{2}{*}{ Brazil } & US\$/real (average) & Federal Reserve Board & Jan-1995 \\
\hline & US\$/real (average) & IMF & Jan-1990 \\
\hline Chile & US\$/peso (average) & Wall Street Journal & Apr-1957 \\
\hline Colombia & US\$/peso (average) & Wall Street Journal & Jan-1957 \\
\hline Costa Rica & US\$/colon (average) & IMF & Jan-1957 \\
\hline Mexico & US\$/new peso (average) & Wall Street Journal & Jan-1957 \\
\hline \multirow[t]{2}{*}{ Peru } & US\$/new sol (average) & Banco Central de Reserva del Perú & Jan-1992 \\
\hline & US\$/new sol (average) & IMF & Jan-1990 \\
\hline Venezuela & US\$/bolívar (average) & Wall Street Journal & Jan-1957 \\
\hline Taiwan & US\$/new Taiwan\$ (average) & Central Bank of China & Jan-1979 \\
\hline India & US\$/rupee (average) & Wall Street Journal & Jan-1957 \\
\hline Indonesia & US\$/rupiah (average) & Wall Street Journal & Jan-1967 \\
\hline
\end{tabular}




\begin{tabular}{llll} 
Country & Data Description & Source & Start Date \\
\hline South Korea & US\$/won (average) & Wall Street Journal & Jan-1957 \\
Malaysia & US\$/ringgit (average) & Wall Street Journal & Jan-1957 \\
Philippines & US\$/peso (average) & Wall Street Journal & Jan-1957 \\
Thailand & US\$/baht (average) & Wall Street Journal & Jan-1970 \\
Nigeria & US\$/naira (average) & Financial Times & Jan-1970 \\
Bulgaria & US\$/lev (average) & Bulgarian National Bank & Jan-1991 \\
Russia & US\$/ruble (average) & Wall Street Journal & Jun-1992 \\
China & US\$/yuan (average) & Wall Street Journal & Jan-1957 \\
Czech Republic & US\$/koruna (average) & Czech National Bank & Jan-1991 \\
Hungary & US\$/forint (average) & National Bank of Hungary & Jan-1968 \\
Poland & US\$/zloty (average) & National Bank of Poland & Jan-1957
\end{tabular}

Note: * Begin using euro data when Greece joined euro area in 2001 
Table 16. Country Sources on Official/Policy Rates

\begin{tabular}{|c|c|c|c|}
\hline Country & Data Description & Source & Start Date \\
\hline \multirow[t]{2}{*}{ United States } & Fed funds target rate (EOP, \%) & Federal Reserve Board & Sep-1982 \\
\hline & Federal funds effective rate (avg., \%) & Federal Reserve Board & Jul-1954 \\
\hline United Kingdom & Bank of England official bank rate (EOP, \%) & Bank of England & Jan-1921 \\
\hline \multirow[t]{2}{*}{ Austria } & ECB main refinancing rate (EOP, \%) & European Central Bank & Jan-1999 \\
\hline & National bank discount rate (EOP, \%) & IMF & Jan-1957 \\
\hline \multirow[t]{2}{*}{ Belgium } & ECB main refinancing rate (EOP, \%) & European Central Bank & Jan-1999 \\
\hline & Discount rate (EOP, \%) & IMF & Jan-1957 \\
\hline \multirow[t]{2}{*}{ France } & ECB main refinancing rate (EOP, \%) & European Central Bank & Jan-1999 \\
\hline & $\begin{array}{l}\text { Time, savings deposit, or short-term cash note rate } \\
\text { (avg, \%) }\end{array}$ & IMF & Jan-1966 \\
\hline \multirow[t]{2}{*}{ Germany } & ECB main refinancing rate (EOP, \%) & European Central Bank & Jan-1999 \\
\hline & Discount rate (EOP, \%) & IMF & Jan-1957 \\
\hline \multirow[t]{2}{*}{ Italy } & ECB main refinancing rate (EOP, \%) & European Central Bank & Jan-1999 \\
\hline & Bank of Italy discount rate (EOP, \%) & IMF & Jan-1964 \\
\hline \multirow[t]{3}{*}{ Netherlands } & ECB main refinancing rate (EOP, \%) & European Central Bank & Jan-1999 \\
\hline & Money market rate on bankers' call loans (avg, \%)* & IMF & Jan-1960 \\
\hline & Discount rate (EOP, \%) & IMF & Jan-1964 \\
\hline Sweden & Riksbank repo rate (EOP, \%) & Sveriges Riksbank & Apr-1987 \\
\hline \multirow[t]{2}{*}{ Switzerland } & SNB target range: upper limit (EOP, \%) & Swiss National Bank & Jan-2000 \\
\hline & Discount rate (EOP, \%) & IMF & Jan-1964 \\
\hline \multirow[t]{2}{*}{ Canada } & $\begin{array}{l}\text { Target overnight money market financing rate (EOP, } \\
\% \text { ) }\end{array}$ & Bank of Canada & Dec-1992 \\
\hline & Money market overnight financing rate (EOP, \%) & IMF & Jan-1975 \\
\hline Japan & Target overnight call rate: Uncollateralized (EOP, \%) & Bank of Japan & Sep-1998 \\
\hline \multirow[t]{2}{*}{ Greece } & ECB main refinancing rate (EOP, \%) & European Central Bank & Jan-1999 \\
\hline & Bank of Greece bank rate (EOP, \%) & IMF & Jan-1957 \\
\hline \multirow[t]{2}{*}{ Portugal } & ECB main refinancing rate (EOP, \%) & European Central Bank & Jan-1999 \\
\hline & Discount rate (EOP, \%) & IMF & Jan-1957 \\
\hline \multirow[t]{2}{*}{ Spain } & ECB main refinancing rate (EOP, \%) & European Central Bank & Jan-1999 \\
\hline & Bank of Spain rate (EOP, \%) & IMF & Jan-1964 \\
\hline \multirow[t]{2}{*}{ Turkey } & 1-week repo rate (EOP, \%) & $\begin{array}{l}\text { Central Bank of the } \\
\text { Republic of Turkey }\end{array}$ & May-2010 \\
\hline & $\begin{array}{l}\text { Average overnight interest rate (average, \% per } \\
\text { annum) }\end{array}$ & $\begin{array}{l}\text { Central Bank of the } \\
\text { Republic of Turkey }\end{array}$ & Jan-1990 \\
\hline Australia & Official cash rate (EOP, \%) & Reserve Bank of Australia & Jun-1959 \\
\hline \multirow[t]{2}{*}{ South Africa } & Repurchase rate (EOP, \%) & $\begin{array}{l}\text { South African Reserve } \\
\text { Bank }\end{array}$ & Nov-1999 \\
\hline & Discount rate (EOP, \%) & IMF & Jan-1957 \\
\hline \multirow[t]{2}{*}{ Argentina } & Reverse repo rate: 7 day (avg., \%) & $\begin{array}{l}\text { Banco Central de la } \\
\text { República Argentina }\end{array}$ & Jun-2004 \\
\hline & $\begin{array}{l}\text { Baibor: 1-day interbank offered rate in pesos (EOP, } \\
\% \text { per annum) }\end{array}$ & $\begin{array}{l}\text { Banco Central de la } \\
\text { República Argentina }\end{array}$ & Apr-1997 \\
\hline \multirow[t]{2}{*}{ Brazil } & Selic - target rate (EOP, \%) & Banco Central do Brasil & Jan-1998 \\
\hline & Selic overnight rate (avg., \% per annum) & IMF & Jan-1964 \\
\hline
\end{tabular}




\begin{tabular}{|c|c|c|c|}
\hline Country & Data Description & Source & Start Date \\
\hline Chile & Monetary policy rate (EOP, \%) & Banco Central de Chile & Jan-1986 \\
\hline \multirow[t]{2}{*}{ Colombia } & BDLR minimum liquidity expansion rate (EOP, \%) & Banco de la República & Jan-2000 \\
\hline & Intervention rate (EOP, \%) & Banco de la República & Apr-1995 \\
\hline \multirow[t]{2}{*}{ Costa Rica } & Monetary policy rate (EOP, \%) & $\begin{array}{l}\text { Banco Central de Costa } \\
\text { Rica }\end{array}$ & Mar-2006 \\
\hline & Basic borrowing rate (EOP, \%) & $\begin{array}{l}\text { Banco Central de Costa } \\
\text { Rica }\end{array}$ & Jan-1982 \\
\hline \multirow[t]{2}{*}{ Mexico } & Target rate (EOP, \%) & Banco de México & Jan-2008 \\
\hline & Bank paper funding rate (weighted avg.) (EOP, \%) & Banco de México & Nov-1998 \\
\hline \multirow[t]{2}{*}{ Peru } & Reference rate (EOP, \%) & $\begin{array}{l}\text { Banco Central de Reserva } \\
\text { del Perú }\end{array}$ & Sep-2003 \\
\hline & Discount rate (EOP, \%) & IMF & Jan-1957 \\
\hline \multirow[t]{2}{*}{ Venezuela } & Commercial bank 30-day deposit rate (avg., \%) & $\begin{array}{l}\text { Banco Central de } \\
\text { Venezuela }\end{array}$ & Aug-1996 \\
\hline & Discount rate (EOP, \%) & IMF & Jan-1964 \\
\hline Taiwan & $\begin{array}{l}\text { Central Bank of China rediscount rate (EOP, \% per } \\
\text { annum) }\end{array}$ & Central Bank of China & Jul-1961 \\
\hline \multirow[t]{2}{*}{ India } & Repo rate (EOP, \% per annum) & Reserve Bank of India & Mar-2000 \\
\hline & Bank rate (EOP, \%) & IMF & Jan-1968 \\
\hline Indonesia & Bank Indonesia rate (EOP, \%) & Bank Indonesia & Jan-1990 \\
\hline \multirow[t]{2}{*}{ South Korea } & Bank of Korea base rate (EOP, \% per annum) & Bank of Korea & May-1999 \\
\hline & $\begin{array}{l}\text { Direct interbank transactions call rate (avg., \% per } \\
\text { annum) }\end{array}$ & Bank of Korea & Jan-1991 \\
\hline \multirow[t]{2}{*}{ Malaysia } & Overnight policy rate (\%, EOP) & Bank Negara Malaysia & Apr-2004 \\
\hline & Overnight interbank rate (EOP, \% per annum) & Bank Negara Malaysia & Jan-1997 \\
\hline \multirow[t]{3}{*}{ Philippines } & Overnight reverse repo rate (EOP, \% per annum) & $\begin{array}{l}\text { Central Bank of the } \\
\text { Philippines }\end{array}$ & Jan-2005 \\
\hline & Overnight reverse repo rate (avg., \% per annum) & $\begin{array}{l}\text { Central Bank of the } \\
\text { Philippines }\end{array}$ & Jan-2000 \\
\hline & Central bank rediscount rate (avg., \% per annum) & $\begin{array}{l}\text { Central Bank of the } \\
\text { Philippines }\end{array}$ & Jan-1964 \\
\hline \multirow[t]{2}{*}{ Thailand } & Policy target rate (EOP, \%) & Bank of Thailand & May-2000 \\
\hline & Bank rate (EOP, \% pa) & Bank of Thailand & Jan-1978 \\
\hline \multirow[t]{2}{*}{ Nigeria } & Monetary policy rate (EOP, \% per annum) & Central Bank of Nigeria & Dec-2005 \\
\hline & Discount rate (EOP, \%) & IMF & Jan-1964 \\
\hline Bulgaria & BNB base rate (EOP, \% per annum) & Bulgarian National Bank & Feb-1991 \\
\hline Russia & Refinancing rate (EOP, \%) & $\begin{array}{l}\text { Central Bank of the Russian } \\
\text { Federation }\end{array}$ & Jan-1991 \\
\hline China & Prime lending rate (EOP, \% per annum) & $\begin{array}{l}\text { China Statistical } \\
\text { Information Center }\end{array}$ & Sep-1972 \\
\hline Czech Republic & Discount rate (EOP, \%) & Czech National Bank & Jan-1993 \\
\hline \multirow[t]{2}{*}{ Hungary } & Base rate (EOP, \%) & National Bank of Hungary & Oct-1990 \\
\hline & National Bank of Hungary discount rate (EOP, \%) & IMF & Jan-1985 \\
\hline Poland & Reference rate (EOP, \% per annum) & National Bank of Poland & Feb-1998 \\
\hline
\end{tabular}




\section{Table 17. Country Sources on Long-Term Bond Yields}

\begin{tabular}{|c|c|c|c|}
\hline Country & Data Description & Source & Start Date \\
\hline United States & $\begin{array}{l}\text { 10-year Treasury bond yield at constant } \\
\text { maturity (avg, \%) }\end{array}$ & U.S. Treasury & Apr-1953 \\
\hline United Kingdom & $\begin{array}{l}\text { Government bonds, } 10 \text {-year nominal par } \\
\text { yield (avg, \%) }\end{array}$ & Bank of England & Jan-1957 \\
\hline Austria & 10-year government bond yield (avg, \%) & Oesterreichische Nationalbank & Jan-1985 \\
\hline Belgium & 10-year government bond yield (avg, \%) & Financial Times & Jan-1980 \\
\hline France & $\begin{array}{l}\text { 10-year benchmark government bond yield } \\
\text { (avg, \%) }\end{array}$ & Banque de France & Jan-1957 \\
\hline Germany & $\begin{array}{l}\text { Fed govt securities w/ residual maturities of } \\
\text { b/w 9-10 yrs (avg, \%) }\end{array}$ & Deutsche Bundesbank & Jan-1957 \\
\hline Italy & Government bond yield: 10-year (avg, \%) & Banca d'Italia & Jan-1958 \\
\hline Netherlands & 10-year government bond yield (avg, \%) & De Nederlandsche Bank & May-1986 \\
\hline Sweden & 10-year government bond yield (avg, \%) & Sveriges Riksbank & Jan-1987 \\
\hline Switzerland & 10-year government bond yield (avg, \%) & Swiss National Bank & Jan-1998 \\
\hline Canada & 10-year benchmark bond yield (avg, \%) & Bank of Canada & Jan-1989 \\
\hline Japan & $\begin{array}{l}\text { 10-year benchmark government bond yield } \\
\text { (avg, \%) }\end{array}$ & Ministry of Finance Japan & Jul-1986 \\
\hline Greece & 10-year government bond yield (avg, \%) & Bank of Greece & Sep-1992 \\
\hline Portugal & 10-year government bond yield (avg, \%) & Financial Times & Oct-2001 \\
\hline Spain & 10-year government bond yield (avg, \%) & Banco de España & Jan-1980 \\
\hline \multirow[t]{2}{*}{ Turkey } & 10-year government bond yield (avg, \%) & Reuters & Jan-2010 \\
\hline & 5-year government bond yield (avg, \%) & Reuters & Dec-2006 \\
\hline Australia & 10-year Treasury bond yield (avg, \%) & Reserve Bank of Australia & Jul-1969 \\
\hline South Africa & $\begin{array}{l}\text { Government bond yields: } 3 \text { to } 5 \text { years (avg, } \\
\% \text { ) }\end{array}$ & South African Reserve Bank & Jan-1985 \\
\hline \multicolumn{4}{|l|}{ Argentina } \\
\hline Brazil & 10-year government bond yield (avg,\%) & Reuters & Nov-2006 \\
\hline \multirow[t]{2}{*}{ Chile } & 10-year BCP government bond (avg, \%) & $\begin{array}{l}\text { Asociación de Bancos e } \\
\text { Instituciones Financieras }\end{array}$ & Jan-2007 \\
\hline & $\begin{array}{l}\text { Interest rates on BCCH instruments: BCP: } \\
10 \text {-year (avg, \%) }\end{array}$ & Banco Central de Chile & Jul-2004 \\
\hline Colombia & 10-year government bond yield (avg, \%) & Reuters & Sep-2002 \\
\hline \multicolumn{4}{|l|}{ Costa Rica } \\
\hline Mexico & 10-year fixed rate bonds (avg, \%) & Banco de México & Jul-2001 \\
\hline \multirow[t]{2}{*}{ Peru } & 10-year sovereign bond yield (avg, \%) & $\begin{array}{l}\text { Ministerio de Economía y } \\
\text { Finanzas }\end{array}$ & Jan-2012 \\
\hline & 10-year government bond (avg, \%)* & Bloomberg & Mar-2006 \\
\hline Venezuela & 10-year government bond yield (avg, \%) & Reuters & Jun-2006 \\
\hline \multirow[t]{2}{*}{ Taiwan } & 10-year government bond yield (avg, \%) & Reuters & Jan-2000 \\
\hline & Government bond yield: 10-year (avg, \%) & Central Bank of China & Jan-1995 \\
\hline India & 10-year government bond yield (EOP, \%) & Reserve Bank of India & May-1996 \\
\hline \multicolumn{4}{|l|}{ Indonesia } \\
\hline South Korea & Treasury bond yields: 10-year (avg, \%) & Bank of Korea & Oct-2000 \\
\hline Malaysia & Government bond yield: 10-year (avg, \%) & Bank Negara Malaysia & Jan-1996 \\
\hline
\end{tabular}




\begin{tabular}{llll} 
Country & Data Description & Source & Start Date \\
\hline Philippines & 10-year Treasury bond rate (avg, \%) & Central Bank of the Philippines & Mar-2003 \\
& 10-year government bond yield (avg, \%) & BIS & May-1998 \\
Thailand & Government bond yield: 10-year (avg, \%) & Bank of Thailand & Jan-2001 \\
& 10-year government bond yield (avg, \%) & BIS & Oct-1999 \\
Nigeria & 10-year Treasury bond yield (avg, \%) & Central Bank of Nigeria & Jul-2007 \\
Bulgaria & 10-year government bond yield: for LT & Bulgarian National Bank & Jan-2003 \\
& $\begin{array}{l}\text { convergence purposes (avg, \%) } \\
\text { 5-year government bond yield: primary }\end{array}$ & Bulgarian National Bank & Oct-2000 \\
Russia & market (avg, \%) & & Jan-2004 \\
China & $\begin{array}{l}\text { GKO-OFZ market rates: long-term rate: 365 } \\
\text { days or more (avg, \%) }\end{array}$ & Central Bank of the Russian & \\
Hungary & 5-year government bond yield (avg, \%) & $\begin{array}{l}\text { Federation } \\
\text { Reputers }\end{array}$ & Jun-2002 \\
Poland & 10-year government bond yield (avg, \%) & Reuters & May-2000 \\
& $\begin{array}{l}\text { Yield on 10-year government debt securities } \\
\text { (EOP, \%) }\end{array}$ & National Bank of Hungary & Jan-1999 \\
& $\begin{array}{l}\text { Long-term government bond yield (avg, \%) } \\
\text { 10-year government bond yield (avg, \%)* }\end{array}$ & European Central Bank & Jan-2001 \\
& & & May-1999
\end{tabular}

Note: * Data linearly interpolated to fill gaps. 